Helsinki University of Technology

Department of Industrial Engineering and Management

Doctoral Dissertation Series 2009/14

Espoo 2009

\title{
CONSUMING STRATEGY
}

THE ART AND PRACTICE OF MANAGERS’ EVERYDAY STRATEGY USAGE

Kimmo Suominen

Dissertation for the degree of Doctor of Science in Technology to be presented with due permission of the Department of Industrial Engineering and Management, Helsinki University of Technology, for public examination and debate in Auditorium TU1 at Helsinki University of Technology (Espoo, Finland), on the $4^{\text {th }}$ of December, 2009, at 12 noon. 
Helsinki University of Technology

Department of Industrial Engineering and Management

P.O. Box 5500

FIN-02015 TKK, Finland

Tel. +358947001

Internet: http://tuta.tkk.fi/

(C) Kimmo Suominen

Phone: +358 445010612

ISBN 978-952-248-222-8 (print)

ISBN 978-952-248-223-5 (electronic)

ISSN 1797-2507 (print)

ISSN 1797-2515 (electronic)

http://lib.tkk.fi/Diss/2009/isbn9789522482235/

All rights reserved. No part of this publication may be reproduced, stored in retrieval systems, or transmitted, in any form or by any means, electronic, mechanical, photocopying, microfilming, recording, or otherwise, without permission in writing from the publisher.

Yliopistopaino

Helsinki 2009 



\section{ABSTRACT}

Strategy seems to have penetrated almost every organization nowadays, from global corporations to small businesses and public organizations. As a result, managers are obligated to follow and submit themselves to the principles of strategic management, a discourse which has become an industry. This empirical research is part of a growing interest in understanding how strategy is practiced in organizations. Particularly, this work studies how managers, as central strategy practitioners, consume strategy.

By drawing on the work of the late Michel de Certeau, the term consumption is adopted as a theoretical framework to explain and describe managers' strategy usage. Consumption is an everyday activity that uses and applies strategy subtly, quietly and opportunistically for the users' own purposes and ends, which may not comply with the original purpose of strategy. This is the art of using strategy.

The research data were produced in three case organizations during 2003-2008. The first case organization is a global industrial organization (Industrial), the second a Finnish polytechnic (Polytechnic), and the third a Finnish insurance company (Insurance). Discourse analytic methods were used to analyze the data.

The results show that the strategy consumption process consists of three overlapping and simultaneous elements. Firstly, five macro-discourses of strategy, militarism, mechanism, humanism, pragmatism and spirituality are used as resources in strategy consumption. Secondly, managers (re)produce strategy by bringing it into being at the societal and organizational level. Here, strategy appears to managers rather unanimously as a way or means to reach the intended vision. Thirdly, managers make something out of strategy by using it originally and creatively for their own purposes through three different usage tactics.

The instrumental tactic applies strategy as an instrument to legitimize and justify managers' activities, solve problems, and lead their subordinates, among others. The playful tactic uses strategy through irony and humor. Here managers use strategy playfully to cope and entertain themselves, as a manifestation of cynicism and resistance. The intimate tactic takes strategy personally by constructing managers' identity and subjectivity in relation to it. Managers may use strategy to glorify themselves as strategic leaders, submit themselves to it, or dis-identify themselves from it.

The results capture the reciprocal dynamics between the micro and macro-levels of strategy practice. They shed light on the practice-oriented strategy research by showing how managers use and poach strategy - being unable to escape it - for their own intentions, with ways that depart from the conventional ideals of strategy. The findings also show how strategy consumption is an artful discursive activity.

As a practical contribution, the work discusses a number of ways in which individual managers can use and apply strategy in their work. The study also brings out factors that should be taken into account when constructing strategy processes and managing strategy work at organizations.

Key words: Strategy, consumption, discourse, manager 


\section{TIIVISTELMÄ}

Strategia näyttää tunkeutuneen nykyään lähes jokaiseen organisaatioon kansainvälisistä suuryrityksistä pienyrityksiin sekä julkisorganisaatioihin. Tämän seurauksena johtajat ovat velvoitettuja seuraamaan ja alistumaan strategiseksi johtamiseksi kutsutun diskurssin periaatteisiin, josta on muodostunut lähes oma toimialansa. Tutkimus pyrkii ymmärtämään, miten strategiaa harjoitetaan organisaatioissa. Työssä keskitytään erityisesti siihen, miten johtajat kuluttavat strategiaa.

Työssä nojaudutaan edesmenneen Michel de Certeaun kuluttamisen käsitteeseen, jota käytetään teoreettisena viitekehyksenä selittämään ja kuvaamaan sitä, miten johtajat käyttävät strategiaa. Kuluttaminen on jokapäiväistä toimintaa, joka käyttää ja soveltaa strategiaa hienovaraisesti, vähäeleisesti ja opportunistisesti kuluttajan omiin päämääriin ja pyrkimyksiin, jotka eivät aina käy yhteen strategian alkuperäisen tarkoituksen kanssa. Kyse on eräänlaisesta strategian käyttämisen taidosta.

Tutkimusaineisto tuotettiin kolmessa case-organisaatiossa vuosina 2003-2008. Ensimmäinen organisaatio on kansainvälisesti toimiva teollisuusyritys (Industrial), toinen suomalainen ammattikorkeakoulu (Polytechnic) ja kolmas suomalainen vakuutusyhtiö (Insurance). Aineisto analysoitiin käyttämällä diskurssianalyyttisiä tutkimusmenetelmiä.

Tulosten mukaan strategian kuluttamisen prosessi koostuu kolmesta päällekkäisestä ja samanaikaisesta osasta. Ensinnäkin viittä strategian makrodiskurssia, jotka ovat militarismi, mekanisti, humanismi, pragmatismi ja hengellisyys, käytetään resursseina strategian kuluttamisessa. Toiseksi johtajat toisintavat ja tuottavat strategian olemassaoloon yhteiskunnallisella ja organisaatiotasolla, jolloin strategia näyttäytyy heille suhteellisen yksimieleisesti matkana tai keinoina kohti haluttua visiota. Kolmanneksi johtajat hyödyntävät strategiaa käyttämällä sitä omaperäisesti ja luovasti omiin tarkoituksiinsa kolmen taktiikan kautta.

Instrumentaalinen taktiikka käyttää strategiaa muun muassa instrumenttina legitimoidakseen ja perustellakseen johtajan toimintaa, ratkaistakseen ongelmia tai johtaakseen alaisiaan. Leikkimielinen taktiikka käyttää strategiaa ironian ja huumorin keinoin. Tällöin johtajat käyttävät strategiaa selviytyäkseen sekä viihdyttääkseen itseään osoituksena kyynisyydestä ja vastarinnasta. Intiimi taktiikka ottaa strategian henkilökohtaisesti rakentaen johtajien identiteettiä ja minuutta suhteessa strategiaan. Johtajat voivat käyttää strategiaa glorifioidakseen itsensä strategisina johtajina tai erottautuakseen siitä.

Tulokset paljastavat vastavuoroisen dynamiikan, joka vallitsee mikro- ja makrotason strategiakäytäntöjen välillä. Ne valaisevat käytäntölähtöistä strategiatutkimusta osoittamalla, miten johtajat käyttävät ja kuluttavat strategiaa omiin tarkoituksiinsa tavoilla, jotka poikkeavat strategian perinteisistä ihanteista. Tulokset niin ikään osoittavat, että strategian kuluttaminen on taidokasta kielellistä toimintaa.

Käytännön suosituksena tutkimus esittää joukon keinoja, joiden avulla yksittäinen esimies voi käyttää ja soveltaa strategiaa omassa jokapäiväisessä työssään. Tutkimus tuo myös esille tekijöitä, jotka tulisi ottaa huomioon organisaatiotasolla strategiaprosesseja suunnitellessa ja strategiatyötä johdettaessa.

Avainsanat: Strategia, kuluttaminen, diskurssi, johtaja 



\section{ACKNOWLEDGEMENTS}

Completing this dissertation has been one of the most demanding and difficult projects of my life. However, I have been fortunate to have people around me who have supported and encouraged me along the way.

First of all, I would like to express my gratitude to my first-class instructor, Professor Saku Mantere, for his encouragement and help during the research process. Saku's frank but gentle feedback turned out to be crucial in several phases of the work. Without his inspiring support, this work would never have been completed.

I want to also thank my original supervisor, Professor Emeritus Veikko Teikari, for his trust in me. The dynamic and constructive approach of my current supervisor, Professor Matti Vartiainen, made it possible for me to defend my thesis in time. My preliminary examiners, Professors Pauli Juuti and Janne Tienari, gave valuable suggestions on how to improve the quality of the manuscript.

In addition to Professor Saku Mantere, my former senior colleagues at the STRADA program have been great examples for me. Dr. Petri Aaltonen has combined academic knowledge with the hands-on approach as a management consultant. Dr. Virpi Hämäläinen showed what it takes to write a popular book and complete a doctoral dissertation. Dr. Heini Ikävalko demonstrated what kind of determination is needed to finish one's thesis.

During the research process, I have had many fruitful discussions with my colleague Jouni Sipponen, whose comments I value highly. I am also very grateful for Jouni Virtaharju for his help and advice. Again, Katriina Karkulehto has read and commented the manuscript regularly, which I appreciate.

I am indebted to those managers, who shared their time and thoughts with me in the three case organizations of this work. The Finnish Work Environment Fund (Työsuojelurahasto) and the Finnish Workplace Development Programme Tykes (Työelämän kehittämisohjelma Tykes) made it financially possible for me to focus on the research work. I also thank David Miller for checking and correcting my English.

I owe a lot to my parents, Jouni and Else, who taught me the value of hard work, perseverance, and entrepreneurship. My sister, Meri, has been the most caring person during the research process. Finally, I want to express my deep gratitude to my wife Emma, not only for reading the manuscript and commenting it, but also tolerating my occasional mental absence during the writing process.

Helsinki, November 2009

Kimmo Suominen 


\section{TABLE OF CONTENTS}

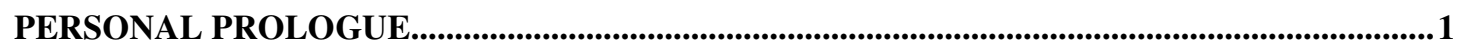

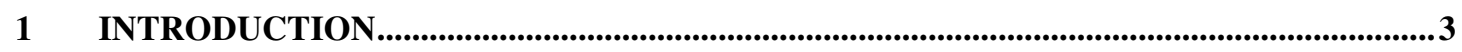

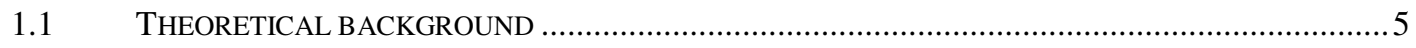

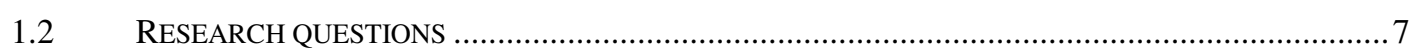

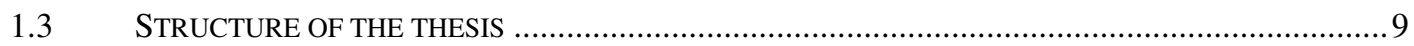

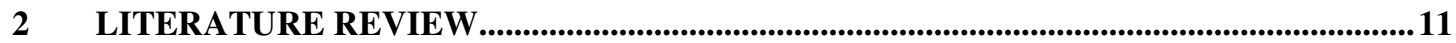

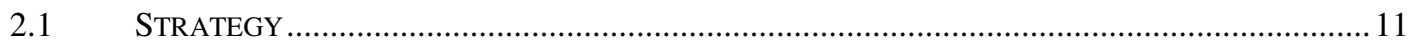

2.1.1 Rational approach ............................................................................................ 13

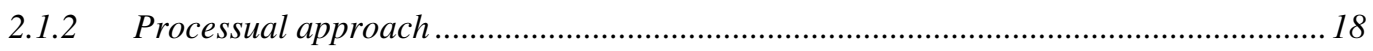

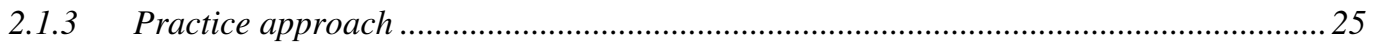

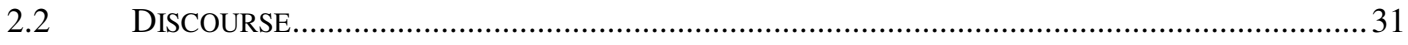

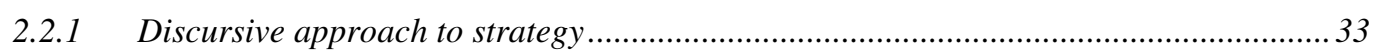

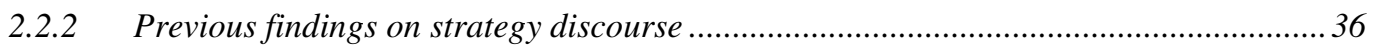

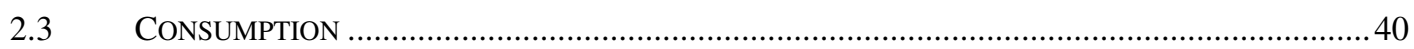

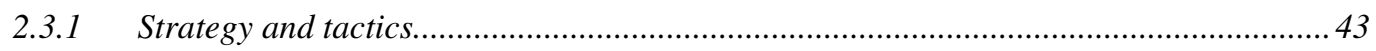

2.3.2 Relevance to strategy research ............................................................................ 45

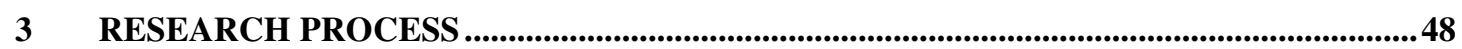

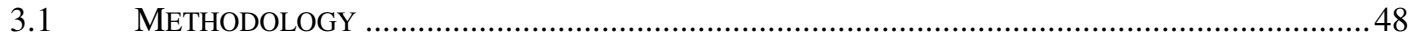

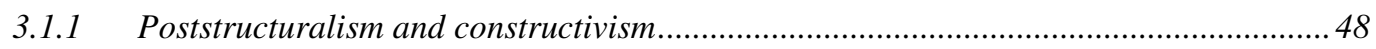

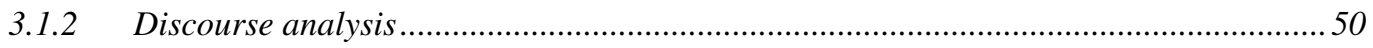

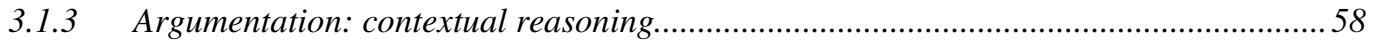

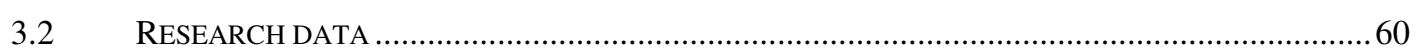

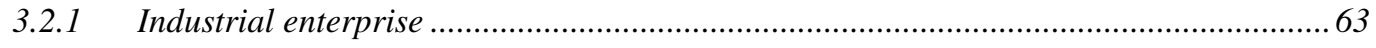

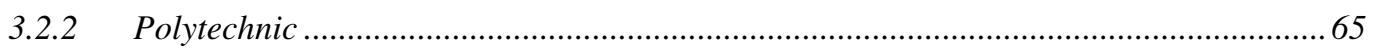

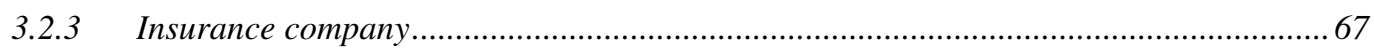

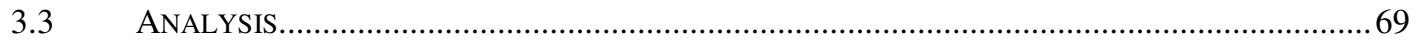

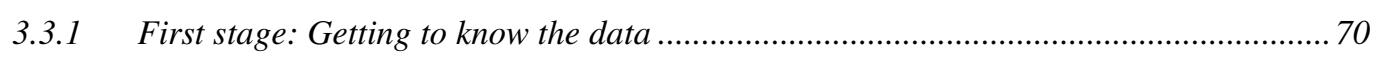

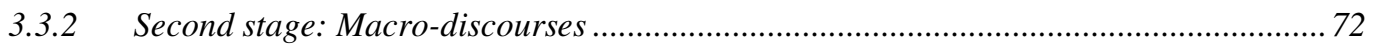

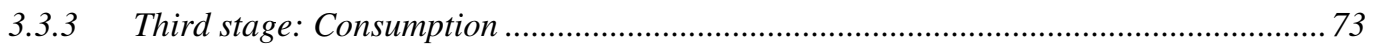

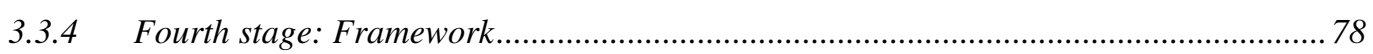

4 ELEMENTS OF STRATEGY CONSUMPTION ……...................................................................81

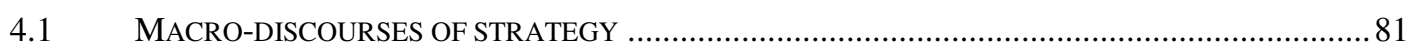

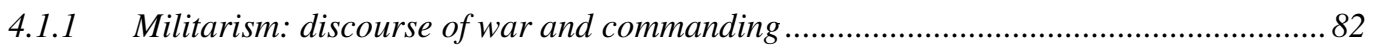

4.1.2 Mechanism: discourse of procedures and systems ................................................... 83 
4.1.3 Humanism: discourse of participation and commitment ............................................... 85

4.1.4 Pragmatism: discourse of concreteness and practicality ......................................... 86

4.1.5 Spirituality: discourse of faith and believing ............................................................. 88

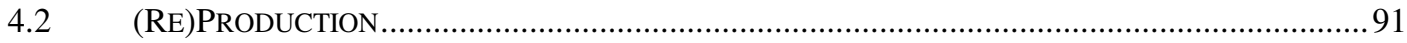

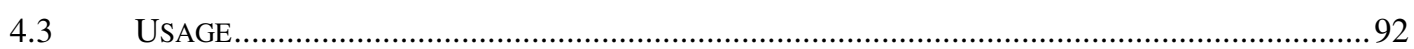

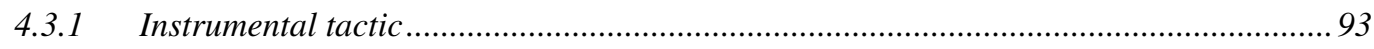

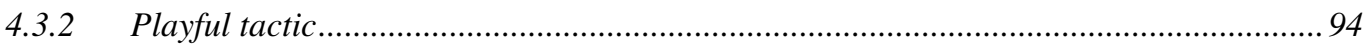

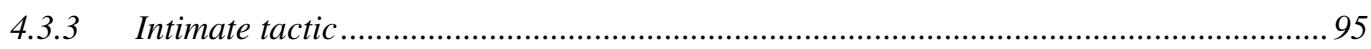

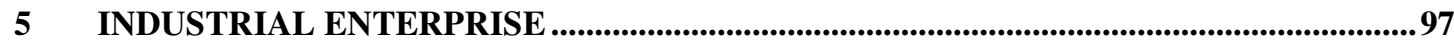

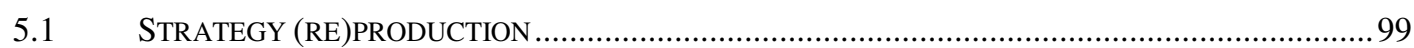

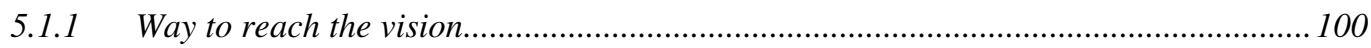

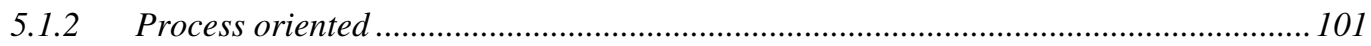

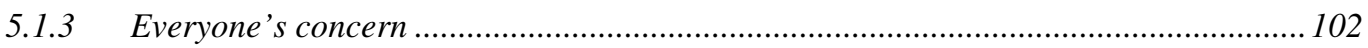

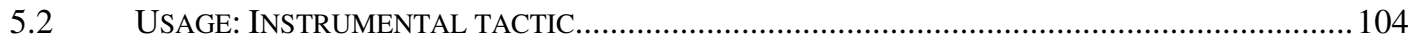

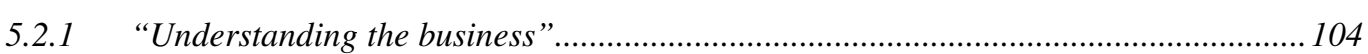

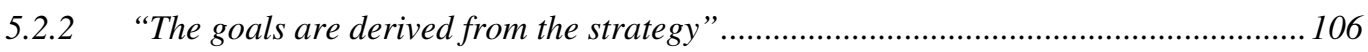

5.2.3 “It's a good guideline, basically” ................................................................................ 107

5.2.4 “We have created our own sub-strategy" ................................................................ 108

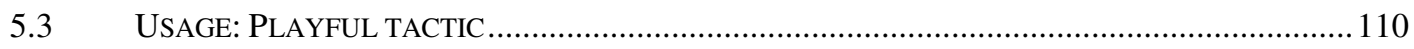

5.3.1 "The ivory tower and the forklift driver" ................................................................ 110

5.3.2 “Occultism at the upper floor" ................................................................................ 112

5.3.3 “Trimmed production plants and service providers" ............................................. 113

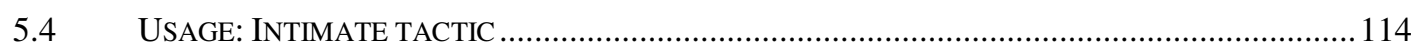

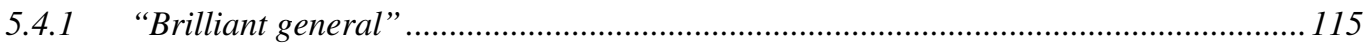

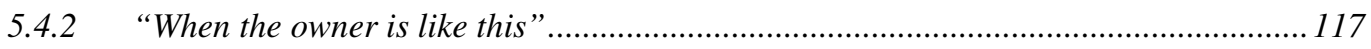

5.4.3 "You don't get help around here" .............................................................................. 118

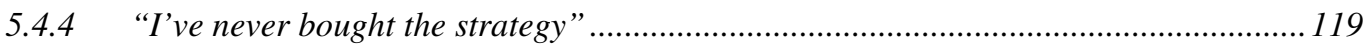

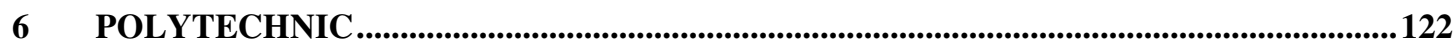

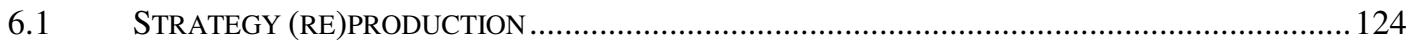

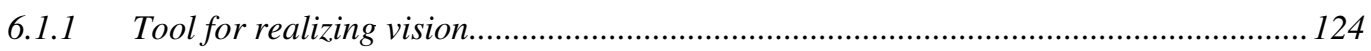

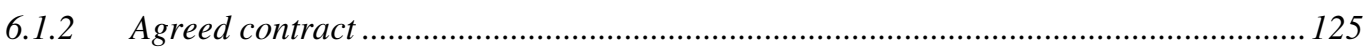

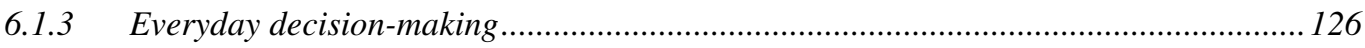

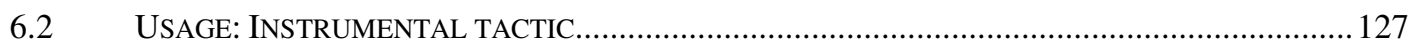

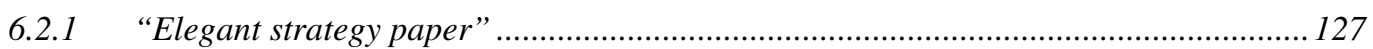

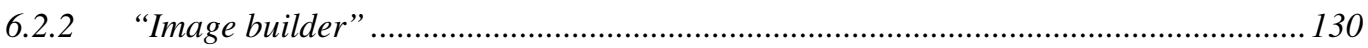

6.2.3 “Strategy - at our own language" .............................................................................. 131

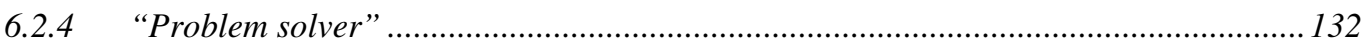

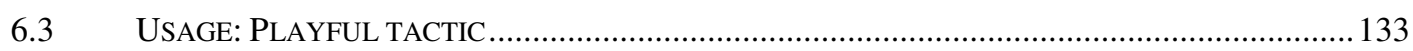

6.3.1 “Have you ever seen anything so miserable? "......................................................... 134 
6.3.2 "Ridiculous administrative systems"

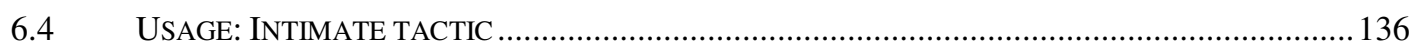

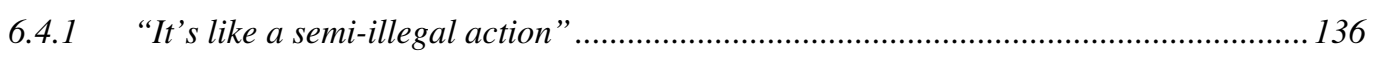

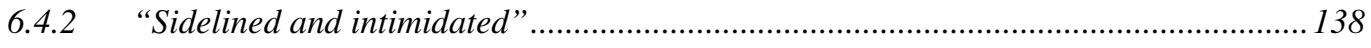

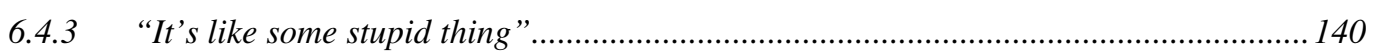

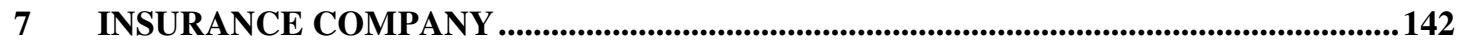

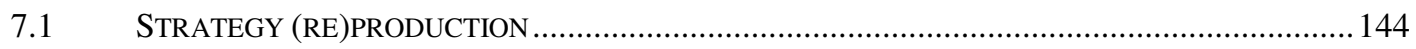

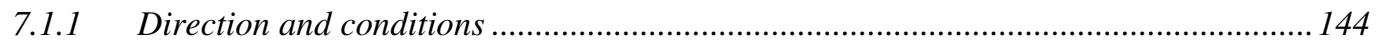

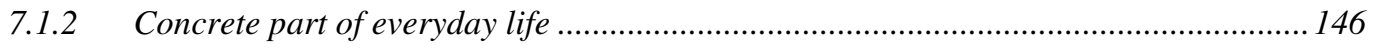

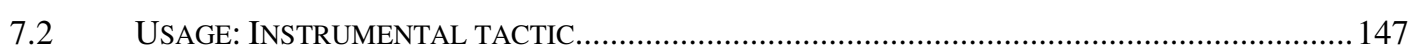

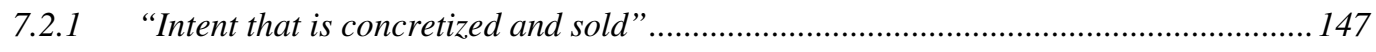

7.2.2 “The bringer of meaningfulness" .......................................................................... 149

7.2.3 “Justification for the decisions and choices" ............................................................ 150

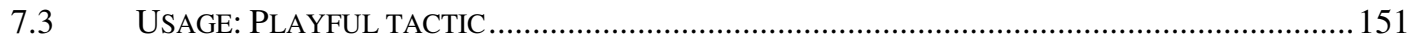

7.3.1 “Biblical commandment and the catechism" .......................................................... 151

7.3.2 “Oh no, did I push the wrong button? "............................................................... 153

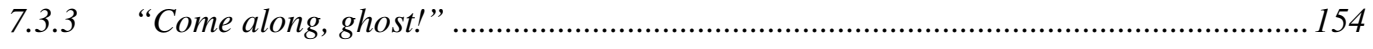

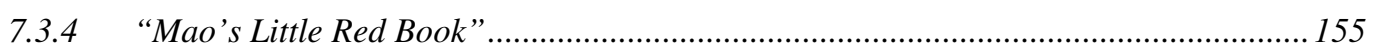

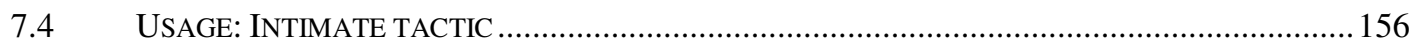

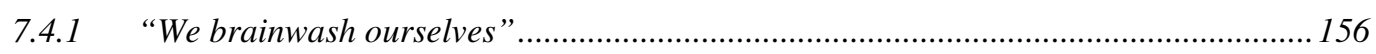

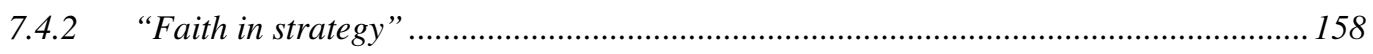

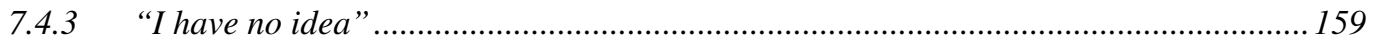

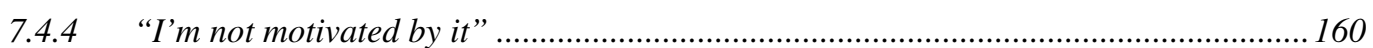

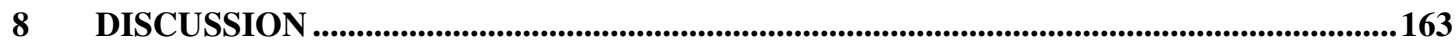

8.1 STRATEGY CONSUMPTION: CONNECTING MICRO TO MACRO ............................................. 163

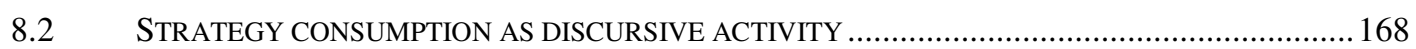

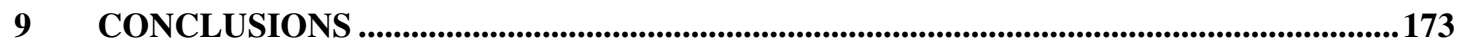

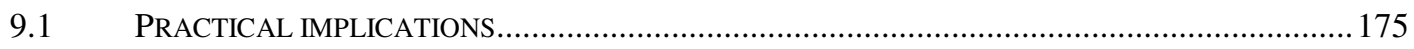

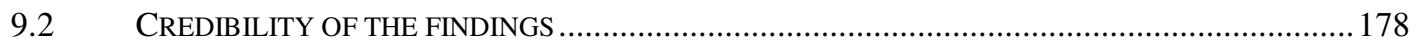

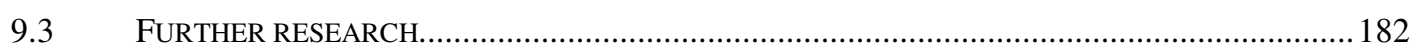

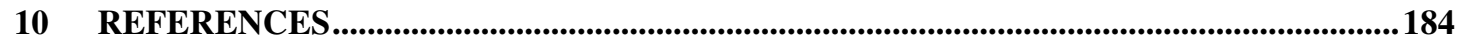

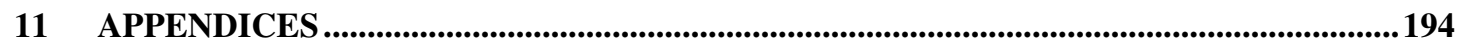

11.1 APPENDIX 1: INTERVIEW OUTLINE OF INDUSTRIAL ..................................................... 194

11.2 APPENDIX 2: INTERVIEW OUTLINES OF POLYTECHNIC...................................................... 196

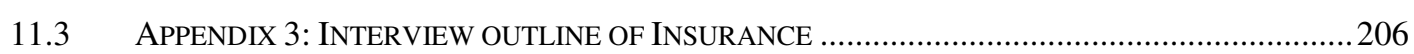




\section{TABLE OF FIGURES}

FIGURE 1 DIFFERENT VIEWS ON STRATEGY AND MY APPROACH TO IT ………………………………...... 39

FIGURE 2 DIFFERENT APPROACHES TO DISCOURSE ANALYSIS (PHILLIPS \& HARDY 2002, 20)...................54

FIGURE 3 THREE DIMENSIONAL CONCEPTION OF DISCOURSE (FAIRCLOUGH 1992, 73) ............................57

FIGURE 4 SCHEDULE OF THE DATA PRODUCTION IN THE CASE ORGANIZATIONS ..........................................61

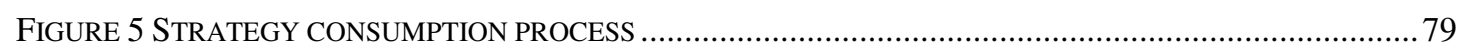

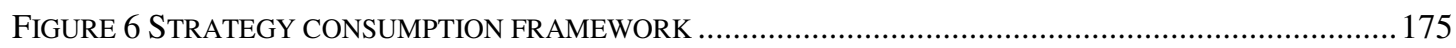

\section{TABLE OF TABLES}

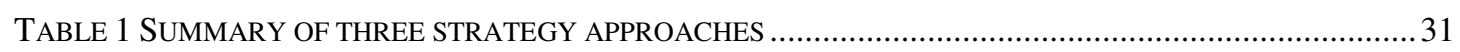

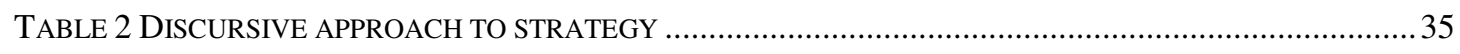

TABLE 3 Two REASONING RESPONSES TO THE REASONING DILEMMA (KeTOKIVI \& MANTERE 2010) ....59

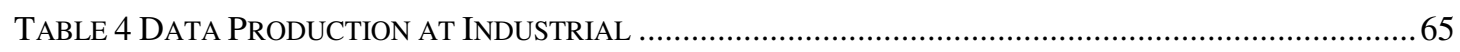

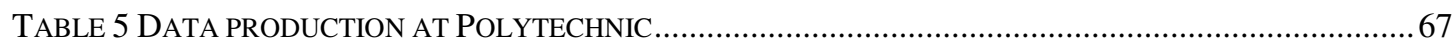

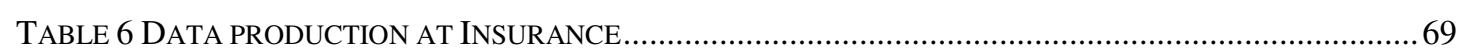

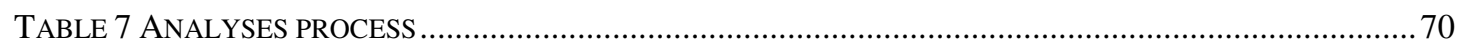

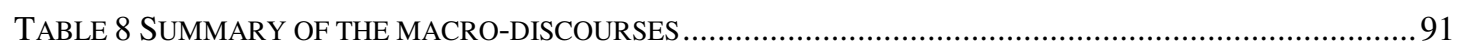

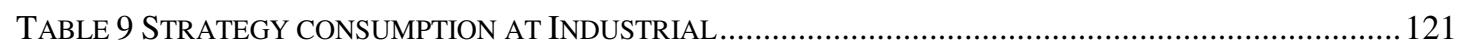

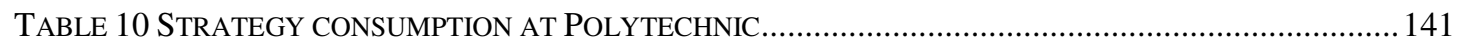

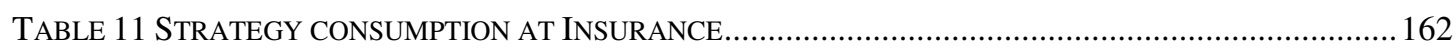

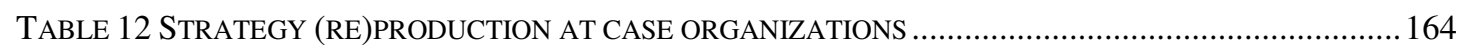

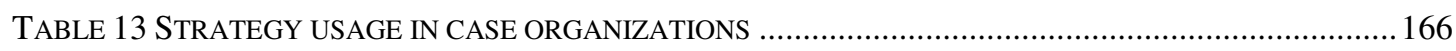

TABLE 14 SUMMARY OF THE CONTRIBUTION TO THE PRACTICE-ORIENTED STRATEGY RESEARCH .......... 167

TABLE 15 SUMMARY OF THE CONTRIBUTION TO DISCURSIVE STRATEGY RESERACH ..............................172 



\section{PERSONAL PROLOGUE}

I became familiar with the concept of strategy by joining the STRADA project in 2001 at the Helsinki University of Technology. STRADA is a research and development program concentrating on studying and developing strategy practices and methods. From that moment on, I have been on a continuous journey of learning and experiencing strategy work in different organizational settings. On that excursion, I have been engaged in strategy both as a researcher, consultant, and user. The motivation for studying strategy in this dissertation stems from these rich experiences.

While working as a researcher and consultant with companies and public organizations, I have noted how strategy has conquered the world of organizing and become the most popular management discipline of our times. Indeed, strategy seems to provide managers and leaders with the ultimate means to manage and lead their organizations and people in a legitimized and justified manner. Although strategy has different emphases in different contexts, almost every organization seems to expect much from it. As a result, many things and practices are nowadays labeled as "strategic" in organizations, which is why the original meaning of the strategy concept has become vague.

I have also had the privilege to discuss strategy with many managers and leaders and I have observed how they have discussed and communicated strategy in their organizations. Many of them have shown extraordinary skills in addressing strategy when seeking to influence their subordinates and other stakeholders. Here, they have used strategy artfully for their own purposes, which has been fascinating to observe and study. Also many other managers have explained to me how they have used strategy for different purposes in their work. These practical experiences and accounts have 
confirmed my theoretical view of strategy as a social construction that is being constructed discursively.

I am also a keen strategy user myself. Having worked as a Project Manager since 2005, I have formulated various strategies together with my team. Some objectives included in them were realized with the desired way, others were not. Some of our realized strategies have been totally unexpected and emergent. However, on many occasions, the process of formulating and creating a strategy itself has been the most fruitful part of strategizing in terms of mutual learning, knowledge sharing and collective sensemaking. Here strategy has provided us with a platform for analyzing the past and planning for the future. During the past few years, I have even created a personal strategy plan for myself, which includes the targets and goals that I want to achieve in my life. (Finishing a $\mathrm{PhD}$ thesis has been one of my personal strategic goals.) For me, such strategy has provided consistency and clarity in the course of life.

However, all this has left me with many open questions concerning the practice of strategy. What is strategy all about, at the end of the day? What do we do when we are using strategy? Why do we use strategy? How do we use it? And for what purposes do we use it? These questions have driven me forward during the research process. My former senior colleagues at STRADA have each studied strategy practice from different angles in their dissertations, for instance, with regard to the social positions of individuals (Mantere 2003), middle managers (Ikävalko 2005), strategy implementation activities (Aaltonen 2007), and organizational identity (Hämäläinen 2007). With this work, I hope to contribute to this academic track by investigating the discursive construction of strategy and, particularly, by showing how managers consume strategy. 


\section{INTRODUCTION}

“How do I see strategy? Well, that's a good question, since I've been fussing with it for 20 years." - Manager, Polytechnic

Strategy has clearly become an institutional must for organizations. It has colonized the world of organizing and has become a popular, powerful and legitimized management discipline in our time. It is exceptional to come across an organization that does not have any plans or objectives labeled as strategic whether it is operating in the private, public or third sector. Indeed, strategy seems to have penetrated almost every organization obligating managers to follow and submit themselves to the principles of strategic management, a discourse (Knights \& Morgan 1991) which has almost become "an industry," and whose members, like consultants, academics and managers, construct and produce strategies and strategic practices that are further applied in different organizational settings (Whittington 2006).

Strategy discourse has power over us. It subjugates us, while we are repetitively participating and performing its ceremonies and practices. It dominates the way we manage others and are managed ourselves. We take many aspects of it for granted, while we threat it as "a natural" feature of organizational life. (Knights \& Morgan ibid.) As a consequence, organizations or managers that do not swear by the principles of strategic management are easily regarded as odd, unusual or un-legitimized.

However, although strategy discourse seems to be a prevailing "management fashion" (Clark 2004) and it is imposed on us by the zeitgeist, the spirit of the times, we are not prisoners of it, not totally. As the quote in the beginning of this chapter reveals, strategy is something you "fuss with." This work investigates what this fuss, called strategy, is about. To do this, I apply the late French theorist Michel de 
Certeau's ${ }^{1}$ (1988) idea of “consumption" as a theoretical lens in this work to explain and understand how managers practice strategy. Consumption, as de Certeau calls it, is a collective activity that makes "transformations of and within the dominant cultural economy in order to adapt it to its own interest and rules" (ibid., xiv). He defines the nature of the consumption as the following:
“'consumption' [...] characterized by its ruses, its fragmentation (the results of the circumstances), its poaching, its clandestine nature, its tireless but quiet ac- tivity, in short by its quasi-invisibility, since its shows itself not in its own prod- ucts but in an art of using those imposed on it." (De Certeau 1988, 31)

Although strategy is a dominant cultural must for managers, they are not completely subordinate to it. Instead, they can use this institutionalized discourse, which is not their own product and which they neither can establish nor create, in novel and creative ways. In this work, managers, as central practitioners of strategy, are regarded as users of strategy, consuming it creatively for their own purposes through their ways of talking. Managers make something of it. They poach it, they use it as an instrument for their own purposes, they play with it, they joke about it, and they use it to construct their subjectivity. By doing this, they engage in a discursive activity called strategy and produce outcomes that are beneficial to them within a larger discursive context. They operate within the discourse of strategy by creating space for themselves to maneuver and cope. They draw on the discursive recourses with particular intentions in mind that may secure some outcomes and mitigate others. (Hardy, Palmer \& Phillips 2000.)

The consumption of strategy manifests itself in the form of tactics. Consumption tactics describe the use of strategy imposed on managers by the dominant strategy orthodox. According to de Certeau, language or rhetoric, as he calls it, is a means of analyzing and understanding the consumption process:

\footnotetext{
${ }^{1}$ Michel de Certeau lived from 1925 to 1986. His book The Practice of Every Day Life, which is used widely as a reference and source of inspiration in this work, was published in English firstly in 1984. In French, the book was published originally in 1980.
} 
"[...] rhetoric offers models for differentiating among the types of tactics. [...] it describes the 'turns' or tropes of which language can be both the site and the object [...] rhetoric, the science of 'ways of speaking,' offers an array of figuretypes for the analysis of everyday ways of acting [...]" (De Certeau 1988, xx)

The everyday practices of managers, tactics and ways of talking, show how they are creatively using, resisting, and appropriating the strategy discourse imposed on them by the orthodox of the strategic management. This strategy consumption represents the art and practice of everyday strategy usage. Through analyzing the talk of managers, we can better understand the social construction process of strategy. It also gives us an understanding of how strategy discourse is used in the everyday life of strategy practitioners.

\subsection{THEORETICAL BACKGROUND}

In terms of academic research, strategy is a vague and complex concept that has been used and studied from multiple viewpoints (cf. Mintzberg, Lampel \& Ahlstrand 1998). In this research, I identify four different streams of strategy research ${ }^{2}$. These streams of thought are rational, processual, practice and discursive approaches. Rational strategy thinking is the most normative approach by its nature. It views strategy making as a rational process driven by top management with the aim of positioning an organization, most often a firm, into markets in the most profitable way. It views strategies as long-term plans. (Cf. Chandler 1962.) The processual view takes a more descriptive view of strategy and investigates the ways and complex processes through which strategies are formulated and implemented (Pettigrew 1992). It does not consider organizations and their people as rational actors, but more likely, views their life as indefinite and unpredictable. (Mintzberg \& Waters 1985.)

The third approach, the practice orientation, regards strategy as something that people actually $d o$ in organizations. Thus, strategy is a practice, a recurrent, habitual, and/or

\footnotetext{
${ }^{2}$ These approaches have also been identified and acknowledged in prior strategy literature. For similar kinds of strategy classifications, see for instance Chaffee 1985, Mintzberg et al. 1998, Whittington 2001 and Juuti \& Luoma 2009.
} 
routinized accomplishment, repetitive performance, that is done in organizations by practitioners such as managers. (Whittington 2003, 2006; Jarzabkowski 2004.) Within the practice-oriented research stream, there are also researchers with discursive interests, that is, their interest is to track and analyze the discursive construction and practice of strategy (cf. Vaara, Kleymann \& Seristö 2004; Laine \& Vaara 2007; Mantere \& Vaara 2008). It is these latter two partly overlapping research traditions, practice and discourse, that this study stems from.

In this work, I adopt a view that language is a central feature and precondition of the practice of strategy. Strategies are discursive constructions produced in talk through a plethora of different discursive practices (cf. Vaara et al. 2004), which we need to understand in order to comprehend the practice of strategy. Also, practitioners, who want to participate in strategy, have to be able to use these practices properly. Thus, I am following Barry and Elmes' (1997) notion that strategy is a dominant narrative, discourse, which has taken different storylines in the past decades. Again, I agree mostly with Knights and Morgan (1991), who define strategy as:

\footnotetext{
"set of discourses and practices which transform managers and employees alike into subjects who secure their sense of purpose and reality by formulating, evaluating, and conducting strategy" (Knights \& Morgan 1991, 252)
}

Within the sociological discussion, there is an ongoing debate about the relation between individual and structure. On one hand, there are views that consider structures (such as discourses) to have ultimate power over individuals, and on the other hand, there are others who claim that structures are constructed by individuals, and not vice versa. Applied to this study, we could ask whether strategy, as a popular and legitimized management discipline, dominates us, or whether we, as practitioners, have power over it? De Certeau (1988) contributes to this discussion by introducing the concept of consumption, which describes how dominant cultural and economic products are used by ordinary people. In this work, I adopt his view to explain and study the role of managers as consumers of strategy.

To sum up, the theoretical background of this study stems from the following ideas:

- Strategy is a social practice that is done in organizations just like any other work (accounting, marketing, etc.). 
- Language is a crucial part of any social practice, including strategy, making it a discursive phenomenon.

- In order to understand the social practice of strategy, we need to understand the discourse of strategy.

- The strategy discourse has power over us, but on the other hand, we can use it creatively for our own purposes discursively as a resource. This activity is called strategy consumption.

\subsection{RESEARCH QUESTIONS}

As highlighted above, this work uses the term consumption (de Certeau 1988) to understand and explain the ways in which managers use and apply strategy discourse in their everyday work. Consumption is something that takes place between the structure, here the discipline of the strategic management, and the subject, here individual managers (Fiske 1989, 36). In other words, it attempts to bridge the gap between the macro- and micro-level analysis by pointing out how these two levels, intraorganizational and extra-organizational, are related to each other (Whittington 2006). This integrative approach (ibid.) aims to show how the societal level strategy discourse (Knights \& Morgan 1991) is consumed in the everyday talk of the managers in different contexts. Thus, the primary research question of the study is the following:

\section{- How do managers consume strategy in their talk?}

However, to be able to fully describe the strategy consumption process, we need to dig deeply into the discursive components of strategy consumption and to be able to outline what discursive practices and resources are used in it (Fairclough 1992, 73). The study also adopts a holistic view on strategy discourse by analyzing both its linguistic and societal aspects (cf. Fairclough ibid.; Phillips, Sewell \& Jaynes 2008). Hence, the two other secondary research questions are as follows:

- What kinds of discursive resources do managers use in strategy consumption?

- What kinds of discursive practices do managers use in strategy consumption? 
Discursive resources are structures that are drawn upon to produce and consume strategy. They are larger discursive entities, such as macro and mega discourses (cf. Alvesson \& Kärreman 2000a), that are present in the extra-organizational macro-level and that may (and often does) incorporate elements of ideology and hegemony. (Fairclough ibid., 85.) The discursive practices are, on the other hand, contextual processes through which texts are produced, distributed and consumed (ibid., 78). These, either individual or collective activities of talk, construct, maintain and consume the discourse and practice of strategy at the intra-organizational micro-level.

Along with paying attention to the general elements of strategy consumption, I want to understand how contextual factors influence and relate to the consumption process. That is why strategy consumption is studied in three different case organizations in this work. The first case organization is a global industrial enterprise (Industrial); the second a Finnish multi-sector polytechnic (Polytechnic); and the third a Finnish insurance company (Insurance). These organizations provide a context of strategy consumption for this study. Thus, the first secondary research questions is:

\section{- How do managers consume strategy in the different case organizations?}

This study seeks to contribute to strategy research in two ways. Firstly, by studying the consumption of strategy, it presents a novel way of looking into strategy practice by drawing on the thinking of de Certeau. Although he is a familiar name in the practice-oriented strategy literature, the empirical works based on his thinking are few in the field of strategy (cf. De La Ville \& Mounoud 2003). While we know that strategy is consumed differently, little is known about the actual consumption tactics, i.e. how strategy is consumed. In this work those tactics are analyzed in detail in case-specific contexts.

Secondly, the results of this study show what kinds of discursive practices are used in the strategy consumption process and how the macro-level strategy discourses are used in micro-level consumption in different contexts. This is a viewpoint that practice-oriented strategy research seeks to take into account (Whittington 2006).

The managers, who are studied in this work, are mostly line and middle managers, but they also include some top managers. All in all, they are a very heterogeneous group consisting of different kinds individuals in terms of their background and experience. 
They are at the core of this research, since they are often key users of strategy. In practice, managers spend plenty of their time communicating and interacting about strategy with others. Strategy language is their resource for shaping issues and events and for gaining influence over people. The way strategy is consumed by them influences and shapes the way others perceive strategy and their role in it. (Johnson, Scholes \& Whittington 2008, 17-22.) From this viewpoint, the results will also give some practical advice to managers and other strategy practitioners.

\subsection{STRUCTURE OF THE THESIS}

This thesis is divided into eleven main chapters. The following, second chapter, discusses the relevant literature related to this study. Firstly, I discuss the history and background of the strategy concept in more detail and provide four alternative approaches to it. By doing this, I outline how strategy has been "consumed" in the previous literature and show how these approaches are still largely relevant in today's strategy practice. Besides that, I shed light on the concept of discourse and highlight how strategy is a discursive phenomenon. After that, the concept of consumption is brought into play and the thinking of Michel de Certeau is discussed.

After the literature review, I will present the research process of this study. I will begin the third chapter by describing the constructivism and poststructuralism, on which the discursive research tradition is built. Then, I will discuss discourse analysis as a research method in more detail, present some different approaches within it, and position my approach into this field. I will also describe the contextual reasoning strategy, which this work draws on. After that, I will discuss the research data and present how they were produced and analyzed.

The results of this study are presented in the three following chapters. The fourth chapter will shed light on different elements of the strategy consumption process. Chapters five (Industrial), six (Polytechnic) and seven (Insurance) will each present case-specific results illustrating the ways how managers consume strategy in case organizations. 
In Chapter eight, the results and key findings of this work and their contribution is discussed and evaluated. In Chapter nine, I will discuss the practical recommendations and lessons that could be drawn from the results. I will also review the credibility of the findings and discuss some possible shortcomings and weaknesses of them. At the end, some further research questions are proposed. Following Chapter nine are the literature (Chapter ten) and the appendixes (Chapter eleven). 


\section{LITERATURE REVIEW}

In this chapter, the theoretical background of the study is discussed. Firstly, I will discuss the concept of strategy by discussing the first three approaches to it, rational, processual and practice. With regard to each approach, I will elucidate how they construct strategy and strategizing in order to gain an understanding of the historical underpinnings and developments of strategy practice. Then, I will move on to the concept of discourse and outline how language has become a central feature of the study of management, and especially, I will discuss how strategy is a discursive construction. At the end of the chapter, the concept of consumption adopted from de Certeau is discussed in more detail.

\subsection{STRATEGY}

Strategy is anything but a clear-cut phenomenon. On one hand, it is a management discipline that has influenced and touched various managers and organizations in different fields and industries. There is a myriad of strategy books and gurus giving advice on how to lead strategically. On the other hand, strategy is a research field that has captured a lot of attention from scholars and academics. And as Bracker (1980) points out, strategy concept has a long and vivid history:

“Our word strategy comes from the Greek strategos, 'a general,' which in turn comes from roots meaning 'army ' and 'lead.' The Greek verb stratego means to 'plan the destruction of one's enemies through effective use of resources.' The concept of strategy in a military or political context has remained prominent throughout history, and has been discussed by such major writers as Shakespeare, Montesquieu, Kant, Mill, Hegel, Clausewitz, Liddell Hart, and Tolstoy. 
The strategic concepts developed by these writers have been used by numerous militarists and political theorists, such as Machiavelli, Napoleon, Bismarck, Yamamoto, and Hitler.” (Bracker 1980, 219)

As can be seen, strategy has its roots in the military field. It was elaborated as the means for planning wars and regulating combats involving a plan on how to outwit the enemy. (Knights \& Morgan 1990.) The unstable, changing, and competitive business environment following the Second World War set the scene for strategy to invade corporate life. Large American corporations were the first in line to adopt its principles and practices.

Nowadays, there is a certain orthodoxy that forces almost every organization to follow the principles of strategic management. Organizations without explicated strategies and strategic objectives are regarded as being without direction or control. Thus, "strategy has become part of the institutional landscape of business education and practice" (Grandy \& Mills 2004, 1156). According to this doctrine, strategy is typically considered a set of rational practices for managing business in the turbulent business environment. (Knights \& Morgan 1991.) Thus, it has been said that strategies have become "the most prominent, influential, and costly stories told in organizations" (Barry \& Elmes 1997, 430).

Why then has strategy become such an institutionalized practice and disciple for today's organizing and managing? The primary reason for the popularity of the strategy concept may lie in organizations' obsession to succeed. According to Mintzberg (1987), strategy provides means for determining a firm's direction, to outsmart competitors, and to maneuver through threatening environments. Or as Ansoff $(1965,94)$ put it: "a firm needs a well-defined scope and growth direction, that objectives alone do not meet this need, and that additional decision rules are required if the firm is to have orderly and profitable growth." Strategy can also be a means for focusing and coordinating a firm's activities. Strategy may also define an organization and create meaning and identity for its members. Strategy might even provide a feeling of consistency and belonging, a psychological emotion that things are under control although the surrounding world is turbulent and unpredictable. (Mintzberg ibid.) Hence, a more appropriate question would be the following: who would not want to apply a practice like this? 
Knights and Morgan (1990, 1991) outline how three societal phenomena - each of which took place shortly after the Second World War - have influenced the development of strategy in the business context. Firstly, the separation of ownership and direct managerial control opened up a discursive space that strategy colonized effectively. Corporations had to explain what they were doing and why they were doing it. Secondly, the war led to changes in market conditions. American companies expanded their operations around the globe, which led to problems in both controlling the production and managing culturally diverse markets. Strategy provided an answer to these challenges. Also, the increased competition between American, European and Japanese companies created complexity and tensions between them. This tension turned out to be a fertile soil for the discipline of strategic management. (Ibid.)

In the following, I will discuss the concept of strategy in terms of three theoretical discussions, each of which provides a unique angle on strategy and strategy research. Discussing these approaches helps us to understand the practice of strategic management better and enables us to get the full picture of it. The approaches are rational, processual and practice. I will discuss the basic premises of each approach and describe how it views the role of the managers, who are considered the strategy users in this study. Also, the contribution of each approach is evaluated in terms of this work.

\subsubsection{RATIONAL APPROACH}

When strategy invaded large American corporations in the middle of the $20^{\text {th }}$ century, strategy-making was a rational design and/or planning process typical for a modern project. The origins of the rational approach can be traced to the writings of authors such as Chandler and Andrews. The former defined strategy as follows:

"The determination of the basic long-term goals and objectives of an enterprise, and the adoption of courses of action and the allocation of resources necessary for carrying out these goals" (Chandler 1962, 13) 
The latter described corporate strategy as follows:

"The pattern of decisions in company that produces its objectives, purposes or goals, produces the principal policies and plans for achieving those goals" (Andrews 1980, 18-19)

As another pioneer of the strategic management, Ansoff (1984, xv), points out, the process in which rational strategies are formulated is called "strategic planning." Later, when studying the premises of the rational strategy approach, Ocasio and Joseph $(2008,250)$ described strategic planning as "a formalized procedure to produce an articulated result in the form of an integrated system of decisions." They also stress the formalization related to strategic planning and describe it with three attributes: 1) "the articulation of goals and objectives for planning," 2) "establishment of a division of authority and responsibility for planning, implementation and control," and 3) "the development of standardized planning procedures" (ibid.). These attributes are characteristic of the rational strategy approach.

\section{BASIC PREMISES}

The rational strategy approach stems from empirical realism, wherein environments are seen as independent, external, and tangible elements (Ezzamel \& Willmot 2008) and wherein organizations are distinguished from these surrounding environments. The organization's environment is "out there" and it is composed of elements like competitors, legislators, partners, trends, threats, and challenges that the organization should both be fitted to and be able to compete with. (Whittington 2001, 11-16.) To some extent, the rational approach of strategy may even consist of an idea that the market forces can be controlled through strategic planning mechanisms by the managers (Knights \& Morgan 1991). Rational strategy thinking originates from the profitseeking businesses, wherein the success of strategy is measured and evaluated by profits and productivity (Whittington ibid.).

The rational view considers strategy a result of an analytical, rational, and "linear" planning process. Strategy is typically a long-term plan of an organization that positions the organization to its environment, allocating its resources, and guiding its actions with regard to its environment and competitors. Such a strategy plan describes 
the long-terms goals and the short-term objectives derived from it as well as the resources necessary for carrying out these goals. (Chaffee 1985; Whittington ibid.) The rational strategy approach tends to view organizations as rational and mechanistic entities. They are instruments - means of gaining strategic objectives. Once these machine-like apparatuses are given strategic goals and objectives and their structure is fitted to the strategy, people are hired to operate this machine in a predetermined manner. The approach emphasizes command and control and arises from military and classical management theory. (Cf. Morgan 1997, 11-31.)

\section{ROLE OF MANAGERS}

The rational strategy view is rather managerialistic by nature. It portrays top managers as having considerable capacity to lead their organizations strategically. When doing so, they go through a prototypical rational decision-making process. In it, they set goals, generate alternative methods of achieving them, and weigh the likelihood of alternative methods to succeed. In the course of this process, they capitalize on the future trends and events that are favorable and avoid or counteract those that are not. (Chaffee 1985.) Hence, the rational approach places great confidence in the readiness and capacity of the top managers to adopt profit-maximizing strategies through rational long-term planning and to implement them successfully.

Along with emphasizing (top) managers' role in strategy-making, the rational approach maintains a dichotomy between planners and implementers of strategy reminiscent of the principles of Taylor's scientific management. It constructs top managers as "commanders," capable of planning sound strategies for others to implement. It portrays them as providers of direction for the organizational members, the "soldiers" who implement strategy by obeying their orders (Bourgeois \& Brodwin 1984; Hart 1992). Top managers can also be "bosses" determining direction through formal and analytical processes and mechanisms. Organizational members are regarded as "subordinates" following these systems (Hart ibid.). Managers can also be viewed as "architects" whose role is to design and manipulate administrative systems and structures that support the particular strategy (Volberda 2003). 


\section{CONTRIBUTION AND CRITIQUE}

Today, the rational, planning-oriented ${ }^{3}$ view of strategy is still relevant and widely applied and accepted in many organizations. Maybe the most prominent reason for the rational strategy view to be so prevailing is the fact that it equips managers with a straightforward model on how to formulate and implement strategy. By reducing the complexity related to strategic management, it sounds simple and clear and it gives executives a sense of being in control. It is also a generalized way of teaching strategy in business schools and MBA programs wherein strategists are socialized to the practice of strategy. Without understanding it and the premises of it, we cannot sufficiently understand the practice of strategy. Again, without being aware of its nature, we are unable to analyze strategy discourse, which is still dominated by the rational ethos of strategy.

In some cases, the rational approach to organizing seems to work fairly well. It has been noted that strategy implementation emphasizing goal setting and control may be helpful in some occasions. Carroll (2000) presents several reasons why MBO (management by objectives) programs lead to improved results when executing strategy. Firstly, they can clarify performance expectations and thus lead to more efficient use of time and effort. Secondly, the feedback system associated with these kinds of approaches makes it possible to identify problems and difficulties that may be resolved more easily in the early stages. Thirdly, from the psychological and motivational perspective, the goals, when accepted, impose a burden in the form of a promise and commitment whose tension is released when the goal is achieved. Fourthly, it is indicated that that effort and performance tend to be higher when organizational members know what and how they are to be evaluated for. Also, goals can serve as the means through which individuals satisfy their needs for achievement and validation of a selfconcept of competence. (Ibid.)

\footnotetext{
${ }^{3}$ However, one must be careful when using the word planning. As Mintzberg (1981) points out, the term can be used in many different ways meaning different things. In this context, planning means future-oriented "thinking" and it is done with a more or less "formalized procedure" likely to produce an "articulated result" (ibid).
} 
However, while concentrating mainly on how firms should develop and formulate sound strategies by means of systematic forecasting, planning, and control mechanisms, the rational approach to strategy has been criticized for ignoring "flexibility." In unstable environments, many situations involve surprises and irregularity that do not give sufficient warning to permit rigid planning processes. In many cases the strategic planning procedures live a life of their own in relation to actual strategic events and situations, and instead of fueling creativity, they can limit or even ruin the strategic potential of organizations. (Volberda 2003.) This is one of the Achilles heals of the rational strategy approach. However, as Whittington and Cailluet (2008) point out, strategic planning has not been abandoned by organizations, although its fall has been predicted for a long time. Instead, it seems that the practice of strategic planning does well in the organizations and has acquired some new manifestations and forms along the way that are more adaptive to changes and adjustments.

The rational strategy approach has also been criticized for creating and maintaining artificial and false dichotomies of strategy, such as "content and process," "formulation and implementation," "thinking and acting," "intent and emergence," and "strategic and operational" (Jarzabkowski 2005, 180). For instance, in his Strategic Management Journal article Mintzberg (1990) points out various reasons why the formulation-implementation dichotomy is false (and even harmful for the organization) in many cases. Firstly, the dichotomy detaching thinking from acting refers to a basic rationality typical of Western thinking: think before you act. It separates muscle from brain corresponding to the classical hierarchy, a mechanical bureaucracy typical of mass production and military. It assumes that data can be aggregated and transmitted up to the hierarchy without significant loss or distortion. However, as Mintzberg points out, the "officers in the rear," who have the power to formulate plans, may not always have the best information or experience of what is happening in the "front row." (Ibid.)

Mintzberg also criticizes the rational view on strategy for not acknowledging the possible resistance related to the intended strategy. The resistance towards the intended strategy may come from the environment, so that although the implementers are willing to implement the strategy, the environment may have changed dramatically, making it impossible to implement it. The environment may also be so unstable that no 
specific strategy can be useful. In other cases it might be the implementers themselves that resist the implementation, based on a lack of willingness, understanding, competence, or motivation. Sometimes the implementers may resist implementation because they sincerely believe and sense that the strategy at hand would do harm for the organization by being unsuitable to the environment or harmful for the organization. Mintzberg criticizes the rational approach to strategy of being too pessimistic and restricted about strategic learning, the collective trial and error process of organization members. (Ibid.)

Mintzberg also points out how the implementers are not robots that can be programmed, but more likely individuals with their own values and interpretations. They make strategy something their own through improvisation and creativity, causing some "slipping" and "drifting" from the intended goal. (Ibid.) This is a particularly interesting notion from the perspective of this study, because it shows how the rational strategy approach has neglected strategy consumption, the improvisatory side of the strategy use and practice, which this work seeks to study. Thus, we need to know how strategy discourse that is still influenced by the ideals of the rational strategy approach is used and consumed by the practitioners of the strategy. Besides that, in order to understand the practice of strategy more thoroughly, a more adaptive and process-oriented reading of strategy is needed.

\subsubsection{PROCESSUAL APPROACH}

As the level of environmental change was increasing and as the rational approach to strategy was considered as too rigid and slow to react into these changes, the need for a more adaptive and flexible approach to strategy became obvious. It was also noted that many realized strategies were "emergent" by nature. They were neither planned nor intended (by top managers and/or strategists), but more likely developed and grown over time through the actions and learning of organizational members. In line with this, it was emphasized that instead of focusing purely on planning and control, organizations should develop their capabilities of strategic learning and thinking. (Mintzberg \& Waters 1985.) 
According to this processual view ${ }^{4}$, strategy is a process rather than a state. The research interest has thus been put on the renewal and growth of organizations and in the entrepreneurial work within them that emphasizes dynamism, action and movement. Processual strategy research is interested in processes in which strategies are formulated and implemented. (Pettigrew 1992.) Unlike the rational strategy approach, the processual view is not as normative by nature, but is more likely to study strategy with descriptive interest, with the aim of understanding how strategies emerge and are realized in organizations, both issues that are neglected by the rational approach.

\section{BASIC PREMISES}

Already in the 1950s and 60s, some highly influential ideas for the processual approach began to emerge. Lindblom's (1959) notion of "the science of muddling through" described public sector policy-maker proceeding with small steps as the objectives given to him are unclear and the environment surrounding him is unstable. On the other hand, Cyert and March's (1963) remarks on the strategy-maker in the business environment remind the latter in various ways. Since the organization is governed by the dominant coalition of disparate interest, the strategy-maker they portray seeks to avoid uncertainty by solving present problems and negotiating with the environment instead of formulating long-run strategies. Mintzberg (1973) has considered these notions as the basic behavioral modes of what he calls the "adaptive" strategymaking mode.

The processual strategy approach views organizations and their environments as more open to each other than the rational approach. The environment is dynamic and unpredictable by nature, and the organization is expected to continually assess its external and internal conditions in order to match them successfully. This calls for adaptation. While in the rational view, organizations deal with and control the environment, the processual view assumes that firms need to change with the environment. (Chaffee 1985.) Thus, the processual thinking, views organizations as "brains" or "organisms"

\footnotetext{
${ }^{4}$ However, it has to be noted here that the processual strategy approach is not a unanimous school, but includes various kinds of stands. For instance, Jarzabkowski (2005, 3-5) divides it into three veins of research: 1) Bower-Burgelman, 2) action (influenced by Mintzberg) and 3) change process (influenced by Pettigrew).
} 
that are constantly learning when processing information and seeking to adapt and survive in changing environments (Morgan 1997, 33-118).

The processual view sees strategies as results of learning and adaptation, a process of detection and correction of error (Argyris 1989). Strategies can also be seen as products of internal processes of mutual adjustment. It has been noted that strategic redirection has not originated from formal planning efforts nor has it been planned by senior executives or strategic planners. Instead, there are examples wherein the actual realized strategy can be something totally different that the indented (planned) strategy. With this respect, the processual approach concludes that the actual realized strategy of an organization can be often perceived only afterwards, from the historical perspective. (Mintzberg \& Waters 1985.)

The processual approach is in many ways different than the rational approach. While the rational approach relies on planning and control, the processual view emphasizes the organization's capabilities for strategic thinking and learning, being open and responsible to new situations and ways of working. As according to the rational strategy approach, strategy cascades downward in the organization, the processual view turns it upside down. In it "strategy comes upward from the firing line, rather than downward from the top" (Bourgeois \& Brodwin 1984, 254). Whereas the rational idea of strategy focuses on direction and control, the processual strategy mode stems from the strategic learning that occurs through continuous action. However, processual strategy does not mean chaos, neither that the management would be out of control. Instead, it is open, flexible, and responsive, willing to learn and adapt. As the rational approach to strategy emphasizes central direction and hierarchy, the emergent strategy mode opens the way for collective action. (Mintzberg \& Waters ibid.)

According to the processual approach, strategy can be traced to small actions and decisions made and carried out by all sorts of people at every level of organization. Small changes can produce major shifts at organizational level and individuals at every level of the organization can contribute to this process. Strategies emerge as people learn to cope and handle situations and soon their actions often converge on patterns of behavior that work. (Mintzberg \& Waters ibid.; Mintzberg 1990; Mintzberg et al. 1998, 176-231.) 
Burgelman (1983) explains the reciprocal relationship of structure and strategy by introducing two types of activity related to strategy. Strategic activities can be either "induced" or "autonomous" in relation to the firm's strategy. Induced activity stems from the firm's strategy and is shaped by its structural content. It literally follows corporate strategy causing no departure from its predefined strategic direction. This kind of activity is desirable for the rational strategy mode, and according to Burgelman, it constitutes the firm's "bulk of strategic activity." Autonomous activity, on the other hand, is behavior that falls outside the current scope of strategy and it is daring and entrepreneurial by nature. This internal corporate venturing, as Burgelman calls it, does not follow strategy, but escapes the current structural arrangements. Although this kind of activity might be occasionally problematical for the current strategy, it usually fuels strategic renewal and precedes changes in corporate strategy. (Ibid.)

Crossan and Berdrow (2003) explain the strategic renewal of an organization from the learning perspective through the $4 \mathrm{I}$ framework. According to the framework, organizational learning proceeds through “intuiting," “interpreting," “integrating," and "institutionalizing." Intuiting refers to the preconscious recognition of the pattern and/or possibilities inherent in a personal stream of experience. Interpreting means the explaining of an insight or idea to oneself and to others. Integrating is the process wherein shared understanding is developed among individuals and coordinated action is taken. Institutionalizing is the process of ensuring that routinized actions occur. (Ibid.)

\section{INTERPRETIVE EMPHASIS}

The process approach to strategy is a broad church that includes many views and ideas. Within the approach, there is also a view that emphasizes the interpretative elements of strategy - and organizational life in general. The view has been influenced by the writings and findings of sociology and cognitive psychology, such as the work of Berger and Luckmann (1967) highlighting the nature of our reality as socially constructed. The view helps us to understand how people in the midst of strategy processes interpret and construct their thoughts and ideas.

Weick $(1995,30-31)$ describes the process in which our reality is constructed with the term "enactment." In organizational life, people actually do not merely perceive the 
environment they face, but produce it. There is no monolithic environment that exists detached from and external to those people, since people are a part of their own environments. People create their own environments and these environments, on retrospect, constrain their actions. Organizations and people perceive their environment (and organizations as well) through action, so that sensemaking is not just interpretation but also ongoing activity. (Ibid.) The environment does not hold for threats or challenges for the organizations as such, but it is the strategist who constructs these in his/her mind. Although he/she can see material things (such as plants, machines, and microchips), he/she constructs their meaning and relationship in his/her mind. (Chaffee 1985; Smircich \& Stubbart 1985.)

The interpretative emphasis views organizations as social constructions, "cultures." They are mini-societies with their own values, rituals, ideologies, and beliefs. Culture is not something that can be changed or touched: it is instead embedded in social interaction and influenced by many factors such as professional groups, subcultures, and ethnic backgrounds. By applying this view, we see that organizations and their environments are enacted domains. We are constantly making sense of our world and these interpretations influence the way we perceive our world and ourselves. (Weick ibid.) This helps us to overcome the false impression that organizations only adapt or react to a world that is given to them. For instance, we learn that "strategy making is a process of enactment that produces a large element of the future with which the organization will have to deal" (Morgan 1997, 149).

The interpretative view considers strategies as social constructions; they are metaphors, interpretative models, schemas, and/or frames of reference through which the organization and its environment is understood and made sense of by its members. Again, stakeholders are motivated to believe and to act in ways that are expected to produce favorable results for the organization. (Chaffee ibid.; Volberda 2003)

Strategy process, according to the interpretative emphasis, is an ongoing sensemaking and sensegiving process. Sensemaking is activity that has to do with "the meaning construction and reconceptualization" of different actors while they are trying to make-sense of strategy and its underlying elements. Sensegiving, on the other hand, is activity that attempts to "influence the sensemaking and meaning making of others." This twofold process of sensegiving and sensemaking is iterative, sequential, and re- 
ciprocal by nature and includes many different stakeholders of the organization. In practice, sensemaking is associated with actions that deal with the understanding processes such as envisioning and re-visioning. Sensegiving, on the other hand, deals with the processes associated with influencing others, like signaling and energizing. (Gioia \& Chittipeddi 1991.) The practical manifestation of it, strategy communication, could be regarded as activity that includes procurement, production, synthesis, manipulation, and dissemination of information at every level of organization in such a way as to give meaning, purpose, and direction to an organization (Westley 1990).

\section{ROLE OF MANAGERS}

From the processual viewpoint, the rational "economic man," portrayed by the rational strategy approach is fiction. People are boundedly rational actors, who have individual wants and motives, and who are limited in their knowledge and capabilities to make decisions and solve problems. (March \& Simon 1958.) According to the processual approach, strategy is less centralized than in the rational approach. In it, managers are willing to act before everything is fully understood. The processual approach also delegates power over strategy from top managers to those who are capable of formulating strategies. (Mintzberg \& Waters 1985.) As the rational approach saw managers as architects of organizational structures, the processual approach sees them as "facilitators" empowering and enabling these processes, as organizational members are "participants," learning and improving while performing. While organizational members are "entrepreneurs" experimenting and taking risks, top managers act as "sponsors" endorsing and supporting this activity. (Hart 1992.) As Bourgeois \& Brodwin (1984) put it:

"The role of the CEO has moved from designer to that of premise-setter and judge. Here, the strategic problem revolves around the CEO's ability to define organization purposes (i.e. set decision premises) broadly enough to encourage innovation, and to select judiciously from among those projects or strategy alternatives that reach his attention." (Bourgeois \& Brodwin 1984, 254)

Instead of seeing the middle managers purely as implementers of an existing strategy, the processual view stresses their role as a strategic asset of an organization. According to it, middle managers gather and apply new ideas and actively influence the decision-making process with their own experience. (Balogun 2000.) According to Ba- 
logun's findings, the managers have a complex and challenging task that consists of four different roles. They are simultaneously expected to undertake personal change, help their staff through change, implement change in their part of the business, and keep the business running. (Ibid.)

\section{CONTRIBUTION AND CRITIQUE}

The processual view on strategy emerged as a critique of the rational strategy approach. It has revealed many shortcomings and weaknesses of the rational approach, and opened up some new horizons for strategy-making. It has challenged the hegemony of the rational strategy approach, and provided many answers to the questions it ignored. As its main contribution, the approach has proven that many - if not all strategies are a combination of intentions and emergent elements. Sticking only to the strategic plans, may be dangerous for any organization. The strength of the approach lies in the fact that most organizations need to pay close attention to their external environment in order to survive and evolve over time.

Although being widely accepted and praised, the processual approach has still remained marginal in strategy practice. This may be due to the fact that it does not provide managers with as tangible and concrete advice on how to execute strategy than the rational approach did. Instead of being a normative approach by nature, like the rational approach, it seeks to provide a descriptive account of strategy. It constructs strategy and strategy implementation as unpredictable and unclear, and it may even diminish managers' feeling of omnipotence. In many cases it may challenge the dominant orthodoxy of organizing, thereby creating conflicts and tensions. The processual strategy approach has been criticized of being too opportunistic by nature. It has been noted that absent strategy in times of crisis might lead to strategic drift (Mintzberg et al. 1998, 224-226). The processual approach has also been criticized for being too modernist and functional by accepting and taking managerial preferences for granted (Grandy \& Mills 2004). Also, it has to be noted that learning merely for the sake of learning can become just another ideology that can hinder our thinking and reasoning on strategy, as planning has done in the other direction.

Although the processual strategy reading has constructed a totally different view of the practice of strategy, it still discusses strategy work on a rather general level. It fo- 
cuses on strategy processes at the organizational level, but says relatively little about the actual practice and practices of strategy. Little is known about the actual learning or adaptation process or the preconditions for them. Neither does it describe how the managers or other individuals consume and use strategy in their work.

\subsubsection{PRACTICE APPROACH}

In recent years, strategy has been given some new flavor from the practice perspective. While the traditional strategy research (most obviously the rational approach) regarded strategy as a property of organizations (an organization has a strategy), the practice approach to strategy regards it as something that people actually $d o$ in organizations. Thus, strategy is a practice, repetitive performance that is done in organizations by practitioners such as managers and consultants. (Johnson et al. 2003; Jarzabkowski 2004; Whittington 1996, 2006.)

\section{BASIC PREMISES}

The practice approach to strategy could be seen as a part of a broader concern to humanize organizational and management research. It attempts to understand human agency in the construction and enactment of strategy, focusing on the actions and activities of a strategy practitioner in it. (Jarzabkowski, Balogun \& Seidl 2007.) To some extent, the practice approach to strategy tries also to overcome the dualism between the rational and processual schools of strategy by concentrating on the phenomenon of strategy itself. The approach takes a sociological eye and treats strategy like any other institutionalized activity in our lives. (Whittington 2007.)

Although the practice view shares many assumptions of the processual approach to strategy, it goes deeper into the actual practices of strategy, referring to different tools and techniques that are used in strategy work. It studies how strategy work is done, who does it, and what tools are used in it (Whittington \& Cailluet 2008). It also seeks to study and locate these actions in a wider context since they are not isolated, but draw upon the socially defined and accepted institutionalized modes of acting. Many tools, technologies and discourses of strategy that are used and applied in strategy work belong to the social infrastructure or industry of strategy having institutionalized 
common properties. The practice approach to strategy tries to uncover this relationship between the micro and macro-level of strategy. (Jarzabkowski et al. ibid.)

The practice approach stems from the social theory and draws on the work of Giddens, Bourdieu and de Certeau, whose attempts have been to overcome the ancient dualism between structuralism and individualism. Whittington (2006) highlights three concepts that should be taken into account when studying the relationship between the structure and individual. First, there is the concept of "society," a field or system, such as shared understanding, cultural rule, language, or procedure, which is guiding, setting the scene, and enabling human activity. Second, there is the concept of "individuality" that refers to people's creative and partly unexpected activity in practice. The third concept is the "actor," which means strategy practitioners, individuals performing and using strategy. The practice theory views these themes as interrelated parts of the whole. The actions of individuals cannot be separated from the society, but society itself is, on the other hand, produced by these actions. (Ibid.)

Jarzabkowski (2004) makes a distinction between practice and practices: "Practice is the actual activity, events, or work of strategy, while practices are those traditions, norms, rules, and routines through which the work of strategy is constructed" (ibid., 454). According to Whittington (2007), the recognition of strategy as practice has pointed in two directions with regard to research efforts. The first direction has led to studies of people's strategy activity, praxis, at the micro-level. In these cases strategy is regarded as demanding work mastered by managers. For instance, Aaltonen's (2007) study shows how organizations have five kinds of activity types relating to strategy implementation. Determining means calculating, devising plans and setting targets. Controlling is related to rewarding, monitoring performance and exerting influence. Communicating is top-down and bottom-up communication and sensemaking. Organizing refers to developing competence and processes and procedures along with team working and modifying organization structure. And interacting with the environment means developing services and products, networking, choosing customers and acquiring information. By categorizing activities like this, the study shows, among others, that strategy implementation is a much more externally oriented phenomenon than the previous research has recognized. (Ibid.) 
According to Whittington (ibid.), the second research direction has led to a wider perspective, wherein strategy is regarded as an industry, whose members in business, consulting, and beyond, collectively produce the strategies and practices related to it. Previous research has proved that strategy processes get different kinds of emphasis in different organizations (Jarzabkowski 2004). Mantere (2005) showed how in a recursively driven strategy process, strategy is formulated, organized and controlled through explicit, predefined, and predictable practices and mechanisms. To some, this kind of strategy work ensures a sense of ontological security, while some consider it to be restricting and limiting by nature. On the contrary, in an adaptively driven process, the practices of strategy are more decentralized and unpredictable by nature, drawing on the mutual improvisation and adaptation of individuals. This kind of strategy-making mode means more control for individuals over strategy. Although this might leave some insecure, it increases individual ownership of strategy. (Ibid.)

Regnér (2003) showed how strategy work obtains different kinds of emphasis depending on whether it is done in the center or periphery of the organization. In the center, strategizing is more deductive by nature, following the spirit of the intended corporate strategy closely. In the periphery, strategizing tends to be more adaptive and creative. There people are more experimental and tentative with regard to strategy and strategy work. (Ibid.)

By drawing on de Certeau, Jarzabkowski (2004) develops the concept of "management practices-in-use," in which she refers to management tools and techniques that are present in macro-institutional and competitive contexts, arising from communities such as industry, academia, consultancy, and the press, and which are diffused by business schools, consultants, and management fashions. These social structures set established practices and conventions for practitioners to use. Although being developed with a particular purpose or intent in mind, the intent or usage style of an actor may not however comply with the original purpose of the particular practice. Practices are open to interpretation and improvisation, depending on the use which they are put to. The recursive use follows the spirit and intent that is originally implied in the practice and is routinized and habitual by nature. The adaptive use, on the other hand, is more creative and appropriative by nature, thus leading more often to unanticipated outcomes. Jarzabkowski labels this activity as "artisan-like inventiveness" (bricolage) 
in which actors produce their own purposeful activities and meanings for the socially legitimized practices that they use. (Ibid.)

Whittington $(2007,1584)$ argues that "it needs the full vision of the sociological eye to grasp strategy's connections, its embeddedness, its ironies, its problems and, finally, both its changes and its continuities." Further on, he proposes guidelines for practice-oriented strategy research. Firstly, he outlines that the sociological eye should seek "structural connections" and "relationships" behind single events and individuals, since they seldom tend to be unique. Secondly, he encourages recognition of the "embeddedness" of strategic activity. Activities are not only affected by the organizational context, but also by the larger social context wherein they are performed. Thirdly, the practice-oriented researcher should pursue "irony;" transform strategy that was once considered a purely economical issue into merely another social practice that is done in organizations. Fourthly, Whittington urges problematization of the "performance" of strategic practice. And finally, he raises the issue of "continuity" in strategy work. Many practices of strategy are done on a regular basis; it seems like they follow certain pattern that has become a routine for the organization. (Ibid.)

\section{ROLE OF PRACTITIONERS}

Besides practices and practice, the practice approach to strategy also takes the practitioners of strategy seriously. By practitioners it refers to those people, who are practicing strategy, doing strategy work, like managers, consultants, and other strategists.

The practice-oriented strategy research has for instance shown that strategic planning includes more creative, original and adoptive activity of individuals than the rational strategy approach has suggested. To describe this rich social process of strategizing at the level of individuals, Nordqvist and Melin (2008) introduced the role of the strategic planning champion to explain and describe how strategy practitioners who introduce, promote and guide strategic planning processes in organizations act. The championship is manifested through three roles. "The social craftsperson" considers and balances expectations and tensions between different stakeholders in strategic planning. They also seek to establish positive and open dialogues and craft alignment and commitment around common strategic views and language. "The artful interpreter," on the other hand, adjusts the general strategic planning practices to the local routines 
and norms of the organization by showing an awareness of the specific ownership and business logic. They skillfully create a balance between the local context and the confidence and legitimacy in personal background and the general planning practice. Thirdly, "the known stranger" balances distance and closeness in interaction with the managers, owners, and board members, by travelling between the various formal and informal arenas of strategy work. The stranger does not represent any internal or external interest although being experienced in the field. (Ibid.)

Practice-oriented research has also shown how the role of middle managers is crucial in strategy work. Rouleau (2005) studied middle managers involved in implementing strategic change in a clothing company. She concluded that the managers' sensemaking and sensegiving practices consist of the micro-practices such as "translating" the orientation, "overcoding" the strategy, “disciplining" the client, and "justifying" the change. In her study, she adopted a viewpoint that strategic change depends on how managers interpret and enact the new orientation during their interactions and conversations. (Ibid.)

An earlier study (Mantere 2008) has also shown how middle managers need reciprocal and enabling conditions from top managers to be able to fulfill their strategic role of implementing, facilitating adaptability, synthesizing information, and championing alternatives, presented by Floyd and Wooldridge (1992). To be able to fulfill the role of implementation, top managers need to open the thought process behind the strategy to middle managers (narration) and make an effort to link strategy to relevant work contexts (contextualization). Middle managers should also be provided with sufficient resources to make changes in everyday work (resource allocation), and their work as implementers of strategy should be respected (respect). To fulfill the role of facilitating adaptability, top managers should encourage new ideas and be open to communication about success and failure (trust). To act in the role of synthesizing information, top managers need to be responsive to new information (responsiveness). To fulfill the role of championing alternatives, top managers need to invite middle managers to planning sessions and invite new ideas (inclusion) and referee between them (refereeing). (Mantere ibid.) 


\section{CONTRIBUTION AND CRITIQUE}

In this work, the contribution of the practice-oriented strategy view is obviously the strongest. As the approach has shown, the practitioners of strategy use strategy and practices related to it with multiple ways. This has targeted my research interests at both acknowledging the strategic practices that are being used and at the usage styles of these practices, i.e. what the practitioners make out of them.

Since I personally find this approach to strategy to be the most suitable for my research setting and thinking, I am relatively biased, what it comes to criticizing it. However, Carter, Glegg and Kornberger (2008) have criticized the practice approach to strategy for adopting too unclear and contradictory a definition of practice, which can mean almost anything, including events, routines and rules, or it may refer to a cry for more practical research approach. They also criticize the practice-oriented strategy view for showing too modest empirical findings as results. (Ibid.) In this work, I try to avoid this shortcoming by going deeply into the discursive practice of strategy. When studying strategy consumption, I also look for empirical evidence from three different case organizations and base my argumentation on those findings.

The three approaches to strategy discussed in this chapter have each provided a different angle on strategy and strategy research. These approaches are summarized in Table 1. In the table, I summarize how each approach defines strategy and strategy work and discuss how it has been researched by the approach. 
TABLE 1 SUMMARY OF THREE STRATEGY APPROACHES

\section{APPROACH DEFINITION, NATURE AND RESEARCH INTEREST}

RATIONAL Strategy is a plan or intent that consists of the long-term goals of an organization. It positions an organization in its environment, allocates its resources, and guides its actions. (Chandler 1962; Andrews 1980).

Strategies are formulated in rational and linear planning processes (Ansoff 1984) wherein top managers play a crucial role. This is followed by strategy implementation where organization and its actions are aligned to the intended strategy.

The research is mainly interested in the content of the strategy, studying which strategy is best for the organization in certain situation.

PROCESSUAL Strategy is a process rather than a state. (Pettigrew 1992.) Strategy is less centralized than in the rational approach. Managers are willing to act before everything is fully understood.

Many realized strategies are emergent by nature. Strategies consist of both intentional and emergent elements. (Mintzberg \& Waters 1985.)

The research interest is in the renewal, growth and entrepreneurial work of the organization, emphasizing dynamism, action and movement. Also, the political aspects of strategy-making are studied.

PRACTICE Strategy is a social practice, something that people do in organizations. Strategy practice is not isolated but draws upon the socially defined modes of acting arising from social institutions. (Whittington 2003, 2006)

Strategy work, strategizing, is done by practitioners of strategy, who draw on different tools and techniques in their work. Although strategy practices are often institutionalized by nature, practitioners may use them in novel and unpredictable ways for their own purposes. (Jarzabkowski 2004)

The research seeks to uncover what is strategy work, how it is done, and by whom. It is also interested in relationship between the micro and macro-level of strategy. (Jarzabkowski et al. 2007)

The practice approach to strategy has also stressed the role of language in strategy work. It sees it as a central feature in strategy practice. The following chapter presents the fourth approach, the discursive view of strategy. However, before proceeding to the discursive strategy view, the concept of discourse needs to be discussed.

\subsection{DISCOURSE}

Recent developments in social science have outlined the role of language. It has been noted that language, and language use particularly, is the most important phenomenon accessible to the empirical investigation in social and organizational research. Due to this "linguistic turn," discourse has become a popular term that has been used widely 
in social and organization research. (Alvesson \& Kärreman 2000b.) The concept of discourse could be understood as a "set of ideas and practices which condition our ways of relating to and acting upon particular phenomena." Discourses are also embedded in social practice, which reproduce the way of seeing "the truth." (Knights \& Morgan 1991, 253.) Discourse brings objects into being. Although they are embodied in texts, they exist beyond the individual texts, which could be characterized as units or manifestations of discourse. (Hardy 2001.) Again, Grant, Hardy, Oswick \& Putnam (2004) define the term organizational discourse as follows:

"[...] structural collections of texts embodied in the practices of talking and writing (as well as a wide variety of visual representations and cultural artefacts) that bring organizationally related objects into being as these texts are produced, disseminated and consumed." (Grant et al. 2004, 3)

Organizations are created through the discourse of their members. Discourse is the primary means by which the members of the organization create a coherent social reality that frames their sense of who they are and what they work for. (Grant, Keenoy \& Oswick 2001.) This process, wherein the social reality is constructed, includes everyday activities such as "differentiating, fixing, naming, labeling, classifying and relating” (Chia 2000, 513). Different types of discourses and discursive practices can be used to justify, legitimize and neutralize different events and decisions (Vaara \& Tienari 2002) in organizations.

The discursive view assumes that reality is socially constructed, which means that reality cannot be perceived objectively. Rather, our social reality is constructed in the ongoing meaning making process of social interaction, wherein language plays a crucial role. ${ }^{5}$ (Berger \& Luckmann 1967.) Discourses create social reality through the production of concepts, objects, and subject positions. "Concepts" are categories, relationships and theories through which we understand the world and relate to one another. Concepts help constituting "objects" by making the material world meaningful. As subjects acquire a right to speak in different discourses, "subject positions" arise. (Oswick, Keenoy \& Grant 2000.) Hardy and Phillips (2004, 302) define social posi-

\footnotetext{
${ }^{5}$ A more thorough description of the constructivist epistemology is provided in Chapter 3.1.1.
} 
tions as "locations in social space from which certain delimited agents can act." They are produced socially as individuals take up positions within a discourse. Different subject positions have different rights to speak; some may have a louder voice, due to their position in the discourse, while others may have no voice at all. According to the discursive perspective, discourses have power over individuals, but at the same time individuals can draw on different discourses as discursive resources for their own purposes (Hardy et al. 2000).

So, to put it simply, discourse is a way of talking and writing about a certain issue, such as strategy, including the statements, concepts, terms, and expressions that are used when constructing it. In recent years, strategy discourse has attracted more and more interest in the strategy research community (cf. Barry \& Elmes 1997; Heracleous \& Barret 2001; Eriksson \& Lehtimäki 2001; Maitilis \& Lawrence 2003; Vaara et al. 2004; Mantere \& Vaara 2008). In the following, I will review the key premises of this discursive strategy view.

\subsubsection{DISCURSIVE APPROACH TO STRATEGY}

The process of strategizing involves usually lots of talk and text, such as memos, meetings, presentations, storytelling, and conversations, among others. Also the outcomes of the strategizing are discursive, like strategy plans, vision statements, speeches and PowerPoint slides, just to mention a few. (Maitilis \& Lawrence 2003.) Managers also spend a lot of time communicating strategy, trying to get others to "buy" strategy with means that are fundamentally discursive by nature. Discourse is their resource by which strategy is constructed, maintained and sustained. (Johnson et al. 2008, 42.) And in order to understand the dynamics of strategizing, we need to understand the discursive practices embedded in the strategy discourse. (Vaara et al. 2004; Barry \& Elmes 1997; Knights \& Morgan 1991; Samra-Fredricks, 2003.) In other words, the research should cover the discursive process where strategy is constructed and made meaningful.

As mentioned, the discursive viewpoint views strategies as social constructions "produced" and "consumed" as talk and text. Strategy is treated as a language used by organizational actors in order to determine, justify, and give meaning to organizational actions. Strategy is a frame or perspective that can be used to shape stakeholders' un- 
derstanding of the environment and to act in ways that are favorable for the organization. Strategy discourse does not simply mirror reality, it creates it. Strategy does not just react to problems existing in organizational environment; but also constitutes and defines those problems. It represents a sort of rhetoric embedded in social practices that makes sense of, legitimizes, and produces certain activities in organizations. (Hardy et al. 2000; Knights \& Morgan 1991.)

Strategy discourse is not a unanimous enterprise but more likely a polyphonic project that receives different kinds of emphasis in different contexts. Within the discursive strategy discussion, there has been a debate whether there is a certain macro-level of strategy discourse, which would influence how strategy is practiced at the micro-level, or whether different strategy concepts are more probably only translated from actor to actor, who operate in a network of actors. The latter view assumes that the meaning of strategy cannot be transferred from one context to another since "strategy concepts in different contexts are different concepts." (Seidl 2007, 198-199.) In this work, I adopt the view that there are certain macro-level strategy discourses that can be located from the wider societal contexts, but that these same discourses can (and most likely will) be utilized and consumed with different ways at the micro-level. However, as de Certeau (1988) brings out, consumption is "an art of weak," which means that it does not have a power to change the discourse it consumes, but it subverts and modifies it. Again, we can make a distinction between societal level strategy discourses that embody general elements of strategic management and organizational level strategy discourses that include contextual and content specific strategies of organizations. That is, while the former discuss strategic management at a general level, the latter argue what an organization plans to do in certain situation. I argue that both of these are by nature strategy discourses.

Strategy constructs subjectivity. Strategy discourse is by no means neutral by its nature; it promotes, defines, and maintains the subjectivity of individuals and groups. Specific discourses produce subject positions for the actors involved, and actors may employ and use these discourses and resist others to protect and enhance their social agency or identity. Subjectivity means "a discursively constructed sense of identity and social agency in specific contexts." (Laine \& Vaara 2007, 30.) The discourse of strategy has become a part of the identity of managers and workers. This popular 
management discipline "transforms them into subjects whose sense of meaning and reality becomes tied to their participation in the discourse and practice of strategy" (Knights \& Morgan 1991, 252). The way strategy is talked positions individuals in relation to others constituting some actors as more powerful than others. It may empower others by giving them a clear mandate to speak and act and disable others by silencing them. Those actors, who have a central role and mandate in organizations' strategy discourse and the ability to engage in it, can - and most likely will - use power over others. (Ibid.)

Strategy has become a buzzword for all activities and disciplines that are trying to establish and maintain the importance of their work. Strategy is a powerful rhetorical device, which turns "normal" into significant and unique. Strategy is also a means to legitimize choices and activities, whereby strategists create a world in which problems defined by them can only be solved by them. (Grandy \& Mills 2004.) Hendry (2000, 969) brings out how the strategy appears to managers as an instrumental technology. This technology applies knowledge of economics and the social sciences, of specific industries and markets, and of the organization's resource capabilities to the creation of economic value and wealth (ibid.). The discursive approach to strategy is summarized in Table 2.

\section{TABLE 2 DISCURSIVE APPROACH TO STRATEGY}

\section{APPROACH DEFINITION AND NATURE}

DISCURSIVE Strategy is a discursive construction, language used by organizational actors in order to determine, justify, and give meaning to organizational actions. Strategy discourse does not simply mirror reality, it creates it. (Cf. Vaara et al. 2004)

Strategy constructs subjectivity in organizations. Strategy discourse is by no means neutral by nature, but promotes and defines subjectivity of individuals and groups. (Knights \& Morgan 1991.) Specific discourses produce and construct subject positions for the actors involved, and actors may employ and use these discourses and resist others to protect and enhance their social agency or identity (Laine \& Vaara 2007).

So, strategy is a discursive accomplishment that is being produced in social interaction. Next, I will provide an overview of how the previous research has described and discussed the process of constructing strategy. 


\subsubsection{PREVIOUS FINDINGS ON STRATEGY DISCOURSE}

In their seminal paper, Knights and Morgan (1991) outlined how the discourse of strategy transforms individuals into subjects, whose sense and meaning is closely tied to their participation in the discourse and practice of strategy. Thus, strategy is not a neutral phenomenon, but more likely a discourse produced in the specific sets of power relationships that define its truth effects both at the societal and organizational level. Strategy has some power effects that Knights and Morgan (ibid.) acknowledge:

“a) It provides managers with a rationalization of their success and failures; $b$ ) It sustains and enhances the prerogatives of management and negates alternative perspectives on organizations, c) It generates a sense of personal and organizational security for managers; d) It reflects and sustains a strong sense of gendered masculinity for male management; e) It demonstrates managerial rationality to colleagues, customers, competitors; government and significant others in the environment; f) It facilitates and legitimizes the exercise of power; g) It constitutes the subjectivity of organizational members as particular categories of persons who secure their sense of reality through engaging in strategic discourse and practice. “(Knights \& Morgan 1991, 262-263)

The work of Knights and Morgan (ibid.) shows how the strategy discourse has power over us and that it is anything but a neutral way of describing the organization and its environment. The power effects of the strategy discourse show how strategy equips managers with certain means that they can capitalize on. Strategy can become a vehicle for managers that they can use for many different purposes at the same time. With regard to this research, it is interesting to find out whether the power effects of strategy are being used by the managers of this study and, especially, how they are used by them.

However, the strategy discourse is by no means a monolithic and unitary entity. While studying the problem of participation in the context of strategy, Mantere and Vaara (2008) identified six different strategy discourses that either promote or prevent participation in strategy work. "Mystification" discourse considers the strategy process as a vision and mission-driven process led by top management. Strategies are crafted in closed workshops and information is restricted. "Disciplining" is a discourse that links strategy to effective organizational discipline and command structures. Top 
managers are also seen as the strategists and strategy work is closely linked to organizational control mechanisms, while the access to information is limited and restricted. "Technologization" discourse promotes strategy that is driven by a specific system and usually the top management defines the systems to be used. Here, strategy work is linked to systems and technologies. "Self actualization" discourse seeks to impart meaning to organizational activities by means of strategy. In it, all actors can participate in strategizing, and strategy work is also done in micro-level. "Dialogization" sees strategy process as a dialogue between different organizational actors and functions. "Concretization" sees strategy as part of the organizational decision making process. (Ibid.)

For me, the strategy discourse classification provided by Mantere and Vaara is not interesting just from the perspective of the participation problem, but because it also shows how strategy is constructed discursively. It indicates how these strategy discourses have an influence on us and our activities in strategy, and also how we can manipulate and use them intentionally for different purposes. It also makes out that strategy is a multifaceted phenomenon that can be constructed in multiple ways.

Strategy creation, the production of strategy, is a top management's effort to manage a company and to have power over people. Employees and middle managers, on the contrary, may show their power by consuming and maneuvering with the strategy in ways that may not meet top management's expectations. Drawing on the critical Foucauldian tradition, Ezzamel and Willmott (2008) analyzed and showed how a new strategy discourse, introduced in a global retailing and manufacturing company, became a new regime of truth in the organization. The central feature of the new strategy was a new accounting metrics, which was to ensure a more disciplined approach to business. However, the strategy was also resisted in the organization. The introduction of team work, a crucial implication and consequence of the new strategy at a shop floor, was resisted through slow-down tactics, by being less cooperative and being resentful. Also, Laine and Vaara (2007) showed how different groups struggled over subjectivity in an engineering firm. While the top management of the firm announced a new strategy for gaining control of the organization, the middle managers initiated unit-specific discourses in order to create room to maneuver in situations where their activities where not supported by the corporate management. Again, the project engi- 
neers at the employee level distanced themselves from the management-led strategy discourse to maintain their own identity.

Strategy is practiced in organizations not only by means of the macro-level discourses, but also by contextual micro-level discursive practices that seek to fulfill certain ends and needs. Vaara et al. (2004) studied airline alliances and found out certain practices that were used in strategizing. For instance, the traditional strategies were problematized, while the benefits of certain strategies were rationalized, objectified and factualized. Mantere and Sillince (2007) acknowledged the role of rhetoric as a discursive practice, especially in the case of the concept of strategic intent. They suggest that the concept can be used as a rhetorical device when creating coherence between multiple intents. Further on, Jarzabkowski \& Sillince (2007) showed empirically how top managers constructed a context for commitment to multiple strategic goals. They argue that managerial rhetoric is contextual and derives meaning from historical backgrounds. They also stress the importance of internal consistency within top management's rhetoric, since it is related to their ability to influence their audience.

Samra-Fredericks (2003) studied the everyday social interaction of strategist with the conversation analytic methods. Her analysis shows how a strategist rhetorically shaped a strategic direction of a firm. The rhetorical skills that were deployed in this interaction include strategist's ability to speak forms of knowledge, mitigate and observe the protocols of human interaction, question and query, display appropriate emotion, deploy metaphors, and put history “to work.” Samra-Fredericks (2004) has also shown how strategy discourse, an area that has for a long time been regarded as an emotion-free field, actually consists of different rhetorical moves to create emotional display.

So far in this chapter, I have discussed my theoretical thinking on strategy. I started the chapter by discussing the two major approaches to strategy, rational and processual. The rational strategy approach is in a way the cradle of all corporate strategy thinking and research, since it addressed the phenomenon first. The processual view emerged as a critique of the rational approach, dominated by economics, by humanizing strategy research and generating more dynamic theories. The practice approach to strategy has been influenced by the processual view. However, it has gone deeper into 
the practice of strategy by studying strategic activity and practices of the managers. To a large extent, these practices and activities are discursive by nature and strategy is mediated by the language that strategist use. (Jarzabkowski 2005, 2-3.) My own approach to strategy stems from a combination of the practice and discursive views on strategy (see Figure $1^{6}$ ) and it is these two theoretical discussions that I mostly want to contribute.

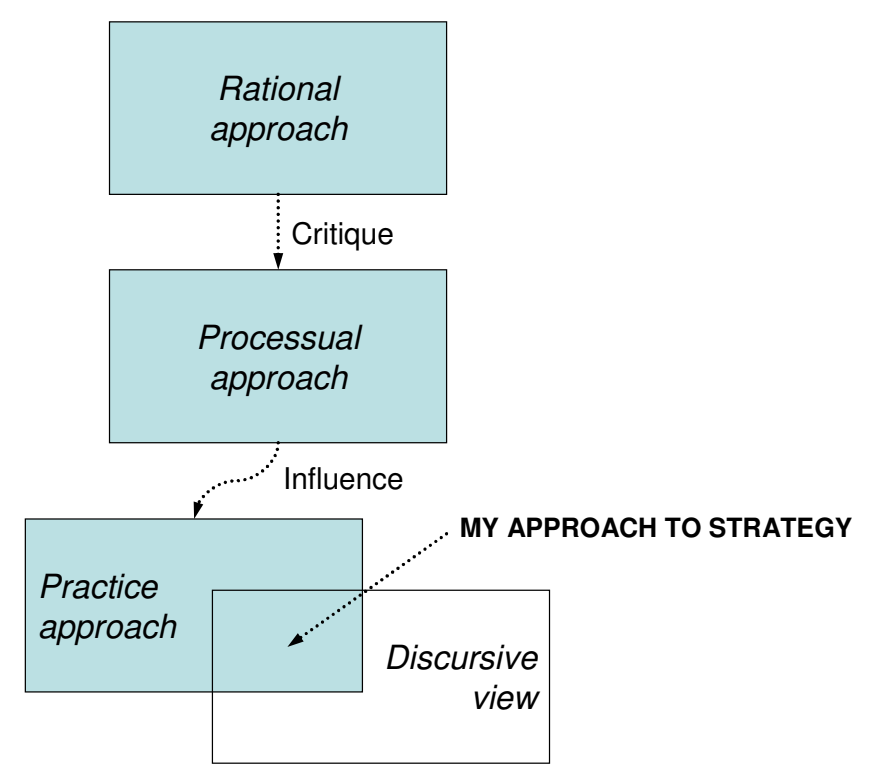

FIGURE 1 DIFFERENT VIEWS ON STRATEGY AND MY APPROACH TO IT

The practice-oriented strategy research discussed earlier has been interested in studying how strategy is practiced in organizations. To do this, it has pursued a sociological stance on strategy research (Whittington 2007). To explain and understand the practice of strategy, it has quoted theorists like Foucault, Bourdieu and Giddens. In this work, I apply the concept of consumption adopted from de Certeau (1988) to study the practice of strategy. Although de Certeau is a rather familiar name within practiceoriented strategy research, there are not many empirical works that have applied his ideas (cf. De la Ville \& Mounoud 2003). Next, I will discuss the concept of consump-

\footnotetext{
${ }^{6}$ However, it has to be noted that the progress from one strategy approach to another has not been as straightforward and plain as this illustration might indicate. There have been, and there are, controversies and disagreements between different views on strategy. Strategy research is a heterogeneous field that embodies many different strategy schools that have their own agendas and research approaches.
} 
tion. Firstly, I will discuss the term at the general level, and then I will apply it in the context of strategy.

\subsection{CONSUMPTION}

Oxford English Dictionary ${ }^{7}$ gives a number of definitions and uses for the verb consume. Firstly, it may relate to physical destruction when it might mean the following:

"To cause to evaporate or disappear; to disperse. To destroy, corrode, wear away; (of fire) to burn up, reduce to ashes. To burn with fire, be reduced to ashes. To swallow up in destruction. To kill or destroy (a person). Of a person: to waste away, esp. from disease; (also) to pine. Also with away. Of a thing: to waste away, decay, rot. Also with away. To cause (organic matter) to decompose."

Secondly, the verb may be used with respect to the exploitation of resources. Then it might mean the following:

"To eat or drink; to ingest. To use up (esp. a commodity or resource), exhaust. To purchase or use (goods or services); to be a consumer of. To spend (money), esp. wastefully; to squander (goods). To ruin oneself through excessive spending. To spend or pass (a period of time), esp. wastefully. Also: to take up (time). To wear out (a thing) by use."

And thirdly, it may have some extended uses, when it means the following:

"To engage the full attention or energy of (a person); (of a feeling or emotion) to overwhelm. To read (literature), watch (film or television), etc., esp. avidly or voraciously; to absorb (culture, art, etc.). To extinguish (a right of action)."

These definitions do not give too good picture of consumption. Instead, they portray it as an activity that destroys, wastes or takes away something that has been produced by

7 Oxford English Dictionary. Retrieved May 23, 2009, from dictionary.oed.com website: http://dictionary.oed.com/cgi/entry/50048269?query_type=word\&queryword=consume\&first=1\&max_to_sh ow=10\&sort_type=alpha\&result_place=1\&search_id=YaDB-oHrMaz-6697\&hilite=50048269. 
someone else. To some extent, these definitions fit also the purpose of this work. De Certeau used the term to describe how different cultural and societal mass-products are used by ordinary people in their everyday life. However, for him the term consumption had a more positive connotation since he concluded that it belongs to our very human nature and has a sort of redemptive effect and meaning in our lives. (De Certeau 1988; cf. Mitchell 2007.) De Certeau investigated the ways in which users operate, not just being passive and guided by the established rules, but being users who are creatively consuming the dominant cultural economy in order to adapt it to their own interests and rules. He raised the consumers, the "unrecognized producers, poets of their own acts, silent discoverers of their own paths in the jungle of functionalist rationality," as the central actors of everyday life (de Certeau idib., xviii).

De Certeau criticized Bourdieu and Foucault, academics who touched similar questions in their writings, of viewing subjectivity too narrowly as a reflex of broader structural process that defines subject positions and generates actions independently of the reflexive subject. For Bourdieu that structural process was habitus, for Foucault is was discourse. However, instead of addressing his own theory, de Certeau provided "a theology" that is rooted in the nature of human spirit. (Mitchell ibid.) The term consumption and the idea of individuals as creative and opportunistic users are in the core of this theology.

In the following, de Certeau (ibid.) gives a practical example of consumption:

"Thus the spectacular victory of Spanish colonization over the indigenous Indian cultures was diverted from its intended aims by the use made of it: even when they were subjected, indeed even when they accepted their subjection, the Indians often used the laws, practices, and representations that were imposed on them by force or by fascination to ends other than those of their conquerors; they made something else out of them; they subverted them from within - not by transforming them but many different ways of using them in the service of rules, customs, or convictions foreign to the colonization which they could not escape. They metaphorized the dominant order: they made it function in another register. [...] They diverted it without leaving it. Procedures of consumption maintained their difference in the very space that the occupier was organizing." (De Certeau 1988, 31-32) 
Here, another modern example of consumption describes how an immigrant uses the systems and structures of his new country creatively:

A North African living in Paris or Roubaix (France) insinuates into the system imposed on him by the construction of a low-income housing development or of the French language the ways of 'dwelling' (in a house or language) peculiar to his native Kabylia. He superimposes them and, by that combination, creates for himself a space in which he can find ways of using the constraining order of the place or of the language. Without leaving the place where he has no choice but to live and which lays down its law for him, he establishes within it a degree of plurality and creativity. By an art of being in between, he draws unexpected results from his situation. (De Certeau 1988, 30)

To de Certeau, consumption is an activity that uses mass-produced and imposed goods, products and systems for one's own purposes. The consumer cannot "own" the product or structure he/she is consuming; neither can he/she escape it in many cases. This leaves him/her in the situation of making something out of the system or product that is imposed on him/her, adopting and using it intentionally. The Indians consumed the sanctions imposed on them by their conquerors subtly and quietly in ways that were not intended by the Spanish. They made them "function in another register," as Certeau describes it. Also, the North African living in Paris insinuates him into the system and laws, which are imposed on him, and manages to establish some space for him. He dwells peculiar to his native Kabylia. Consumption like this is characterized by its ruses and fragmentation. It poaches and shows itself not in its own products, but in an art of using those that are imposed on it, making it clandestine, invisible, tacit and tireless activity by nature. (ibid., 31.) The products of the tactical consumption are thus difficult to study, since they have no place - only the space of their moments of being (Fiske 1989, 35).

Fiske (ibid., 1-47) discusses the idea of consumption from the perspective of popular culture. He concludes that the consumption of the popular culture is motivated by pleasure, the pleasure of producing one's own meanings of social experience and the pleasure of avoiding the social discipline of the power-bloc. Also, the everyday act of consumption is always an act of production, since consumption is always production of meaning. Consumption is also "the art of being in between." Using their products for our purposes is the art of being in between production and consumption. For in- 
stance cooking could be characterized as the art of being in between the supermarket and a unique meal. (Ibid.)

Although de Certeau raises the everyday practices of individuals at podium, he does not, however, want to return to individuality. Moreover, de Certeau views subjects as mere vehicles or authors of the consumption. His investigation is concentrated on "modes of operation" or "schemata of action" rather than "the subjects who are their authors or vehicles" (De Certeau ibid., xi). His interest is not in individual subjects per se, but more likely in the modes or logics of operations, consumption tactics that the consumers use, which he considers to be socially shared by nature.

\subsubsection{STRATEGY AND TACTICS}

De Certeau uses the terms "strategy" and "tactics" to explain and illustrate the relationship between structure and human action. By strategy he refers to actions of the powerful that are derived and oriented towards the realization of abstract models. Strategies emerge when institutions such as business, armies, cities, or scientific institutions separate themselves in order to establish a panoptical position. Strategies are able to produce, tabulate and impose these places. As in management rhetoric, strategies are being made to distinguish its own place, the place of its own power and will, from an environment. This Cartesian attitude is an effort to delimit one's own place in a world bewitched by the powers of others. This is also a typical attitude in modern science, politics, and military strategy. (De Certeau 1988, 36-39)

In de Certeau's thinking, strategy can refer to anything between cities, organizations, and even individuals that is recognized as authorities and which has power over themselves and others. Strategies have their own spaces: they manifest themselves through the physical artifacts and/or discourses. Strategy can be set by someone with power, or it may have created its own power. Strategy is relatively stable and enduring having an institutionalized status. Strategy cherishes stability and order and it has power of knowledge making it an asset of the strong. Strategy is not a consumer, but more like a good or commodity that is being consumed with different tactics. (Ibid.)

Tactics, on the other hand, area "calculus which cannot count on a proper" belonging to the other. "A tactic insinuates itself into other's place, fragmentarily, without tak- 
ing it over in its own entity, without being able to keep it at a distance." (Ibid., xviiixx.) Tactics describe the use of the products imposed by the dominant economic order. Usage or consumption, as de Certeau calls it, is collective activity that uses these products off and within the dominant cultural economy in order to adapt them to user's own interests and rules. (Ibid., xiv) So, while strategy forms an entity of its own, tactics are practices that are inter-discursively related to many other entities. Tactics are acts of the weak taking place within a discursive space of strategy. In de Certeau's thinking they represent a hope of redemption over the panopticon of modern society. (Mitchell 2007.)

Tactics are everyday resistance rooted not only in the realization of human nature, but also activity that is morally and universally good by nature. Although dependent upon the possibilities provided by circumstances (places), tactics do not obey the law of the place for they are not defined or identified by it. They can only manipulate and divert these places. Tactics means playing and foiling in the other's game, the space instituted by others, since tactics lack their own place. They have to get along in established networks and places. People have to make do with what they have. (De Certeau ibid., 18.) In tactics, subjects rely on opportunistic moments where they can exploit and use gaps, discontinuities or inconsistencies (Knights \& Mueller 2004, 60).

De Certeau describes tactics with many metaphors and examples. The users consume social codes and language like renters make changes and modifications in the apartments they rent, but which they do not own. They "furnish" them with their own history, accent and phrases. Also, the pedestrians consume streets by filling them with their aspirations, desires, and goals, although they are unable to change or reshape the city map. (Ibid., xxvi.) Consumption might also mean making something of the images broadcasted by television or reading a health magazine and making something out of it (ibid., 30). Also, consumers show artful skills, like driving in the streets of Rome or Naples, when tacking in the middle of the labyrinths of powers (idib., 18).

According to de Certeau, the central practice in the consumption process is language (or "enunciation" as he calls it). According to de Certeau, the act of speaking consists of four characteristics. Firstly, speaking operates within the field of the linguistic system. Secondly, it affects the appropriation of language by its speakers. Thirdly, it establishes the present relative to time and place, and fourthly, it posits a contract with 
the other in a network of places and relations. (Ibid., xiii) De Certeau (1980) concludes that the study of rhetoric is a key to uncovering the everyday tactics used by users.

"Relevant, for example, are the various 'figures 'or 'tropes' analyzed by rhetoric [...] There is indeed nothing astonishing in such homologies between the ruses of practice and operations of a rhetoric. Rhetorical figures play their successful or unsuccessful moves out on a restricted terrain which is precisely that of selfidentity, namely, of rule-governed syntax and of the 'literal 'or 'proper' meaning in just that sense evoked above: that is, a lawful space of identity and exclusion defined against its external other. Rhetoric offers the possibility of a manipulation of language dependent on the appropriate occasion and aiming to seduce, entrap, or invert the linguistic position of the receiver." (De Certeau 1980, 8)

De Certeau outlines how the discipline of rhetoric offers models for differentiating among different types of tactics. While describing turns and tropes, they offer a way to analyze everyday acting. De Certeau not only concerns discourses as normative frameworks, but also as tools that are manipulated by the users. (De Certeau 1988, 21)

\subsubsection{RELEVANCE TO STRATEGY RESEARCH}

Today, strategy has colonized the world of organizing by becoming a popular and powerful management discipline or fashion of our time. It is a practice that has penetrated more or less every organization, forcing managers to create "strategies," formulate "strategy" processes, and make "strategic" decisions. It seems that organizations belong to a community of strategy made up of other organizations, consultants, business schools, and business media, which bring back and forth and reproduce different strategy practices that influence the way organizations are to be managed (Seidl 2007). Like the sanctions imposed by the Spanish conquerors, strategy is hard - if not impossible - to escape in organizations. You just have to live with it and consume it.

The story of Indians using and consuming sanctions that were imposed on them by the Spanish conquerors reminds us of the hegemony of strategic management in many ways. As the Spaniards tried to impose their own culture on the Indians by giving the rituals, representations, and laws, so does the discipline of strategy invade the everyday life of managers. However, the Indians, although unable to reject or alter those 
sanctions, used or consumed them for their own purposes, making them something quite different from what the conquerors had in mind. (De Certeau ibid., xiii.)

Nowadays, I argue that an individual manager is as incapable to change or escaping the sanction, strategy discourse, imposed on him/her as the Indians were before. However, although strategy is a management discipline that cannot be escaped, it does not keep practitioners, like managers, as its prisoners. Following de Certeau's argument (ibid.), managers, regarded as consumers, use and consume strategies discursively for their purposes and means. Although strategy discourse promotes and defines their subjectivity, they can also consume it in order to promote certain subjectivities. Strategy is no more a discourse that is being imposed to them, but more like a product or consumable good that can be "poached" or used for totally different purposes than has actually been meant.

De Certeau's idea of consumption encourages us to study how macro-discourses are used and poached by the managers. By doing this, it also connects the macro-level structures to the micro-level talk. De la Ville and Mounoud (2003) have applied de Certeau's idea of consumption in the field of strategy research. Their work, which is one of the few studies focused on strategy consumption, showed how managers resist the dominant strategy design by doing "la perruque," a term used to describe how employees might divert time from the organization to do something that benefits the employees, instead of following the strategic direction of the organization. They also showed how strategy consumption may take the form of narrative tactics, such as poaching, which manipulates and haunts larger discursive arenas, humor, and plotting, telling stories to uncover the causal structure of the events. De la Ville and Mounoud use the term "poaching ability" (ibid., 97) to describe managers' ability to use and transform the grand discourse of strategy. They also point out how consumption entails two sides: a form of acceptance of the good and the creative and pleasure seeking form of using it. ${ }^{8}$

\footnotetext{
${ }^{8}$ This dualistic idea of the nature of consumption turned out to be a very important finding with regard to my analysis, see Chapter 3.3.3.
} 
In this work, I use de Certeau's thinking in the context of strategy. My attempt is to use de Certeau's idea of consumption to make a contribution to the practice approach to strategy and to the discursive strategy view. The idea of consumption provides us with a framework to study and understand what managers make out of strategy and strategic management. It gives us a framework to understand how managers use the strategy discourse that is imposed on them. However, since consumption is hidden and fragmented on the terrain, which it does not own, it is scattered all over the "official" strategy discourse. This makes it hard to study, which might be the reason why there is so little research on it (cf. De la Ville \& Mounoud 2003).

Here, I have proposed that strategy is a discursive practice and that managers construct, produce and, especially, consume it in their talk. This idea constitutes a central theme of this work, where my aim is to study how managers consume strategy in their talk. In the following, I will describe how I have set out to do it. 


\section{RESEARCH PROCESS}

In this chapter, I will give an account of the research process of this study. Firstly, I will discuss the discourse analytic research tradition in general terms, and then define how I have used it in this work. Secondly, I will describe the research data and discuss how they were produced in the case organizations, and also reflect on my own role as a researcher in each case organization. Finally, I will describe how the data were analyzed using discourse analytic methods. The chapter was written in a personal tone in it to signal reflexivity (Alvesson \& Sköldberg 2000) and authenticity, and to describe the choices that have been made during the research process, in other words, to make the process as transparent as possible for the reader.

\subsection{METHODOLOGY}

This research stems from the discursive perspective and applies discourse analytic methods to analyze the data. Before going into discourse analysis more thoroughly, I will discuss the constructivist and poststructuralist underpinnings of the discursive approach.

\subsubsection{POSTSTRUCTURALISM AND CONSTRUCTIVISM}

Poststructuralism, by drawing on postmodernism, abandons the modernistic idea of the Enlightenment. Instead of relying on rational universal solutions and explanations, grand narratives of modernity that would guarantee progress in the development of knowledge, it stresses the role of local and provisory stories. It breaks free from the 
structuralist view, according to which there is a dominating center that governs the structure. (Alvesson \& Sköldberg 2000, 148)

Poststructuralism views the nature of language as an ambivalent, metaphorical and constitutive play with signs. It questions the ability of the researcher to give objective and truthful accounts about reality since reality can be represented in a number of ways, and human experience is always discursively constituted. Poststructuralism does not embrace the idea of developing a best interpretation with superior or holistic meaning. (Ibid., 148-152.) Poststructuralists claim that subjectivity is constructed through language, and is a process rather than a structure. To them, human subjects are effects, rather than a cause, of the social and discursive process. How we speak and how others address us, constitutes our subjectivity in different contexts. Discourses and language can give expression to particular power relations and lock people into some forms of subjectivity. Certain discourses (such as strategy) may empower while others silence. (Ibid., 164-165.)

Constructivism is an epistemological theory about the nature of knowledge. It claims that knowledge is constructed in social interaction, not discovered from the world as the modernist and positivist research tradition explains. (Silverman 2006, 128-130.) Thus, constructivism could be seen as a counterpart of the modernist, realistic scientific tradition. Constructivism takes a critical stance towards taken-for-granted ways to understand the world and knowledge. It is critical of the idea that the world can be observed empirically and objectively and believes instead that we understand the world based on our historical and cultural background, wherein the concepts and categories through which we perceive and construct our world are derived. Knowledge and our view of the world is constructed and sustained in the social process of interaction. What we regard as the truth, our current accepted ways of understanding the world, is not is a product of objective observations of the world, but more likely of the everyday social process of interaction in which we constantly engage with each other. Here, knowledge and our world are literally socially constructed by their nature. However, the construction process of our social reality is not unilateral, but more likely a many-faced and polyphonic process wherein many simultaneously existing socially constructed worlds and realities co-exist. (Burr 1995, 2-4) 
The basic premise behind the constructivist epistemology relates to the poststructuralist idea of the nature of language, and to the notion of the nature of reality. According to the constructivist approach, language does not mirror reality as the realist epistemology assumes, but constructs, maintains, and renews it. (Alvesson \& Kärreman 2000b; Potter \& Wetherell 1987, 32-55.) While a realist assumes that by analyzing language we can learn what strategy is, a constructivist studies language to learn how strategy is produced and constructed discursively. In this work, I am also interested in studying how strategy is consumed discursively.

Constructivism takes knowledge as theory-driven, viewing the research process as interplay between a theory base and the phenomenon that is being studied. Through this interaction the model of reality, called knowledge, is being created. This means that the researcher approaches the problem he/she is studying with certain preconditions that also affect the possible solution. Constructivism does not regard the phenomenon under investigation and the researcher as separate. More than likely, findings are determined by the philosophical positions of the researchers. Constructivism believes that researchers are never objective or value-neutral. This calls for transparency from the researcher both to explain the theoretical assumptions and to justify the decisions and choices that have been made during the research process. (Mir \& Watson 2000; Alvesson \& Kärreman 2007.) Hence, all this means that research is the construction of the researcher, and not a neutral nor objective account of what has "really" happened or what the research phenomenon is "really" about.

\subsubsection{DiSCOURSE ANALYSIS}

Discourse analysis is neither a clear-cut research method as such, nor a unified enterprise, but more like a theoretical framework that includes and allows different kinds of applications and focus areas (cf. Potter \& Wetherell 1987, 6-8). Discourse analysis has been influenced and informed by a variety of studies from sociology, anthropology, and linguistics; it is a "plurivocal project" (Grant et al. 2004). The common 
ground for all these approaches is a strong constructivist view, which regards reality as socially constructed, as described previously ${ }^{9}$.

While social reality is constructed and maintained discursively, discourse analysis aims to uncover and study these construction processes and consequently provide us with an understanding of the construction, maintenance, and change of social reality (Hardy 2001). As Phillips and Hardy $(2002,2)$ put it, this is valuable because "without discourse, there is no social reality, and without understanding discourse, we cannot understand our reality, our experiences, ourselves.”

The term discourse refers to practices of talking and writing, in general. To be more specific, it can be defined as a set of texts and those practices that produce, disseminate, and consume them with the aim of bringing an object into being. Our social reality is produced and made real and meaningful for us through discourse. Discourse analysis is an approach to explore this construction process of the social reality. (Ibid., 3.)

As mentioned earlier, there are multiple, somewhat competing and differing views, each of which has their own idea of how the discursive construction of social reality should be studied. In the following, I will discuss three complementary classifications of discourse analysis and evaluate their relevance and contribution for my research process. Firstly, I will bring out four different discourse types presented by Alvesson and Kärreman (2000a). Then I will review a discourse analysis classification provided by Phillips and Hardy (ibid.). And finally, I will sum up the discussion by discussing the thinking of Fairclough, who gives a rather comprehensive and holistic view of discourse analysis in his book Discourse and social change (1992). Each approach has contributed something to my data analysis, which is why they deserve to be discussed in more detail.

\footnotetext{
${ }^{99}$ However, there are also researchers within a discourse analytic research tradition that emphasize more realistic view of reality, calling the view a “critical realism” (see Fairclough 2005).
} 


\section{VARIETIES OF DISCOURSE}

In their article, Alvesson and Kärreman (2000a) recognize two major dimensions that seem to differentiate discourse analysts in their studies and approach. The first dimension is the connection between discourse and meaning. The question is whether the discourse precedes and incorporates cultural meaning and subjectivity or should it be understood purely as a text and talk that is only loosely coupled to meaning. This distinction has led researchers to think differently about the matter. Some believe that discourse and meaning overlap totally and are tightly coupled; others consider them loosely coupled, while still others assume that they are totally uncoupled. In practice, the question is about how far the conclusions drawn from the discourse studied can reasonably go, or should they be restricted entirely to the text and the use of language. Alvesson and Kärreman call the other spectrum of the dimension "discourse determination," wherein the social and psychological consequences are also taken under consideration in the analysis, and the other spectrum as "discourse autonomy," which, on the other hand, stands on its own and is only loosely coupled to the social. (Ibid., 1129-1133.)

The distinction between autonomous and determinant discourse is very interesting and fruitful in terms of my own research. In this work, I studied how managers consume strategy discourse in their talk, which means that it was not just the text that I was interested in, but also its usage and interpretation. Nevertheless, the usage and consumption of strategy is in many cases clandestine by its nature and cleverly "hidden" under the official strategy rhetoric. This means that the text itself must be taken under close scrutiny. However, consumption and use are by no means context-free by nature, but more likely closely embedded into an organizational context. This is why my approach to discourse analysis is similar in various ways to discourse determination. In addition to showing how the contextual factors are related to the discourse, I was also interested in drawing conclusions on how and why the managers use strategy in certain ways, which requires that their cognition, motives, and subjectivity are in some way incorporated in a discourse. Here, discourse drives and embodies the subjectivity of managers and I was interested in analyzing it.

The other dimension identified by Alvesson and Kärreman concerns the formative range of discourse. The "close-range" interest in discursive studies emphasizes local 
and situational contexts of discourse. Language is here associated and related to a certain social context wherein it is produced. Discourse is considered to be local and rather context-specific by its nature. On the contrary, the "long-range" view sees discourse as a global and universal and not so context-specific by nature. For instance, strategy discourse could be seen as a sort of universal discourse that has been spread across different contexts. (Ibid., 1133.)

As an example, Alvesson and Kärreman point out four versions of discourse analysis, each having its own particular emphasis and interests. The "micro-discourse approach" concentrates on social texts and calls for detailed study of language in a specific context. The "meso-discourse approach" is likewise interested in local context but along with the detailed textual analysis, seeks to compare and generalize texts between similar contexts. The "Grand Discourse approach" expands the range and pays attention, for instance, to discursive construction of organizational reality. The "Mega-Discourse approach" refers to those standardized ways of referring to general and universal discourses constructing a certain type of phenomenon. (Ibid., 11331134.)

The discourse typology provided by Alvesson and Kärreman (ibid.) shows that discourse is manifested at various levels, and it is these levels that should be taken into account in the analysis. However, they "express sympathy" for a more reduced range in the study of discourses and warn about the tendency to work with too grand or overly view of discourse. However, they also stress the risk involved in sticking too closely to the language and in forgetting the surrounding social context. The discourse analyst has to able to hear the story and understand the context where it was produced. (Ibid., 1145.) I read this advice as a suggestion to take into account both the text/discourse and the social context where it was produced, which is also what I aim to do in this work. In Alvesson and Kärreman's terms, my aim is to show how the grand and mega Discourses are consumed at the micro-level.

\section{DISCOURSE AND POWER}

While Alvesson and Kärreman (2000a) emphasized the difference between the discursive approaches that either take the contextual factors into account or not, Phillips and Hardy (2002) contribute to the discussion by emphasizing the role of power in the 
discourse analytic research tradition. Phillips and Hardy identify (ibid., 19-27) four different traditions of research within the discourse analytic research stream (see Figure 2). The first two, "social linguistic analysis" and "interpretive structuralism," are both un-critical approaches by nature. The social linguistic analysis takes a close look at the text in order to provide an insight into its organization and construction, and to understand how the text constructs certain phenomena. By doing this, the approach provides an understanding of the micro dynamics of the discourse. The interpretive structuralism widens the range of analysis and focuses on the social context and the discourses that support it. For instance, such studies have analyzed how organizational change is produced and legitimized by managers (Heracleous \& Barret 2001).

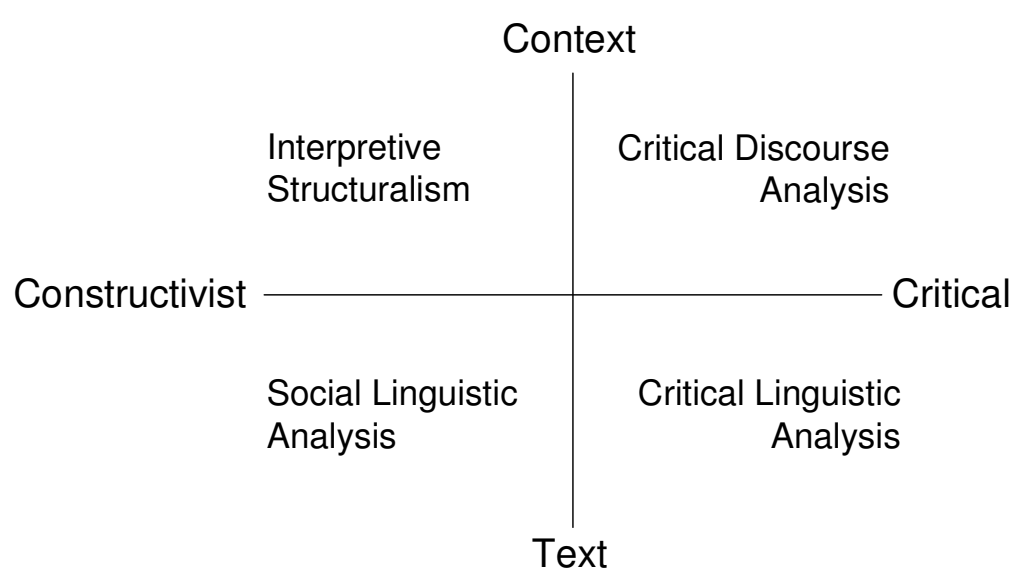

FIGURE 2 DIFFERENT APPROACHES TO DISCOURSE ANALYSIS (PHILLIPS \& HARDY 2002, 20)

The third and fourth traditions, "critical discourse analysis" and "critical linguistic analysis," are critical by nature, as their names suggest. The latter, critical linguistic analysis is focused on individual texts, but with a strong interest in the dynamics of power that surrounds them. It is concerned with the micro dynamics of the text. Critical discourse analysis, on the other hand, focuses on the role of the discursive activity in constituting and sustaining unequal power relations at group and institutional level. Researchers are interested in analyzing discursive struggles that privilege some and marginalize others. Drawing on the work of Fairclough (1992) and having a strong Foucauldian tradition, this stream is focused on studying how discursive structures shape the social space in which the actors act. (Phillips \& Hardy ibid., 23-27.) 
The issue of power is an interesting one with regard to my research. How should I position myself in relation to it? I am not as critical in my work as critical discourse analysis in its purest form, which assumes, by drawing heavily on Foucault, that discourses have definitive power over us. Like Foucault (1972) himself put it: “discourse is not the majestically unfolding manifestation of a thinking, knowing, speaking, subject, but, on the contrary, a totality, which the dispersion of the subject and his discontinuity with himself may be determined" (ibid., 55).

However, not all critical discourse analysts are so totalitarian in their view about power. Even Fairclough (ibid., 56-57) criticizes Foucault for being too pessimistic about the resistance to power. Also, Mumby (2004) suggests that organizational discourse studies should take a closer look at the dynamics of actual discursive processes. He also argues that too little time is spent examining the micro practices of the discourses that constitute organizational reality and their relation to larger macro processes of organizational power. Mumby also encourages researchers to explore subjectivity "as a complex, communicative accomplishment" that has a contradictory nature. He emphasizes that "self and world are created in relation to each other, and have no meaning as independent spheres of existence.” (Ibid., 252.)

By drawing on de Certeau (1988), I also argue that while powerful discourses are hard, if not impossible, to escape, they are not complete totalities that leave no room for us. In other words, we are not powerless before them: they do not subjugate us totally. More likely, we consume them for our own purposes playfully and creatively. Again, we do not consume these discourses only for creating and maintaining our subjectivity, but also for pleasure and resistance to the dominant power structures. So, power is present in my research, but not in way that the critical discourse analysis might regard it. My approach to discourse analysis recognizes power and its presence in the discourse, but leaves more room to maneuver for the individual (cf. Laine \& Vaara 2007). By doing this it tends to turn the Foucauldian idea upside down and "empower" and emancipate individuals, constructing them as users of discourse, and considering discourses as resources that they can use and draw on. In this way, discourses are used as strategic resources (Hardy et al. 2000) to shape and ensure certain ends meaningful for the individual. 


\section{HOLISTIC VIEW}

Norman Fairclough is one of the seminal figures in the field of critical discourse analyses. I found his ideas and thoughts about discourse analysis highly fruitful in many ways. By the term discourse, Fairclough means "language use as a form of social practice, rather than a purely individual activity or a reflex of situational variables" (Fairclough 1992, 63). According to Fairclough, this has some serious implications. Firstly, discourse is a mode of action, which means a form with which people can act upon the world and especially upon each other, as well as a mode of representation. Secondly, there is a dialectical relationship between discourse and social structure. This means that while discourse is shaped and constrained by social elements, such as social class, discourse itself is also socially constitutive. (Ibid., 63-64.) Here, again, I find this two-way approach to discourse useful in terms of my own work.

Fairclough distinguishes three different aspects of constructive effects of discourse. First of all, discourse contributes to the constructions of what are typically referred to as "social identities" and "subject positions." Secondly, discourse helps construct "social relationships" between people. And thirdly, discourse contributes to the construction of "systems of knowledge and beliefs." These three effects correspond to the three functions of language and dimension to the meaning that coexists and interact in all discourse. Fairclough calls these functions "identity, relational, and ideational." (Ibid., 64.)

Fairclough's attempt to bring together three analytical traditions of discourse analysis is presented in Figure 3. In the center of his model is a linguistic tradition of analyzing text and linguistics ("text") closely. At the other end, there is a macro-sociological tradition of analyzing social practice in relation to social structures ("social practice”). Between these two different ends, there is a micro-sociological tradition of analyzing the social practice, production, distribution, and consumption of discourse ("discursive practice”). Through these facilitating practices people actively produce and make sense of discourse. (Ibid., 73.) This is also the level at which de Certeau's idea of consumption could be placed. 


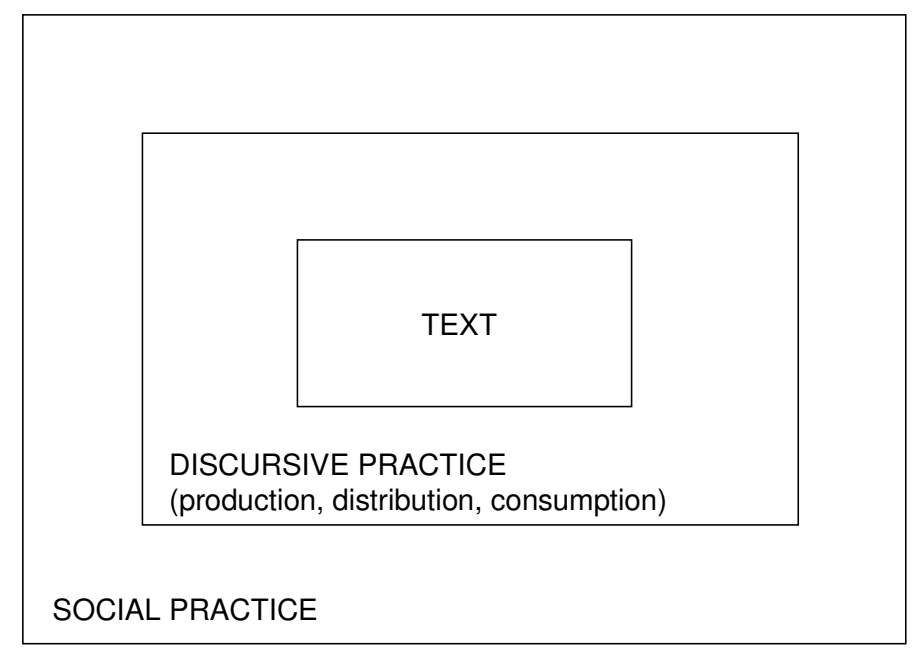

FIGURE 3 THREE DIMENSIONAL CONCEPTION OF DISCOURSE (FAIRCLOUGH 1992, 73)

Intertextuality is one of the central concepts of Fairclough's thinking. The concept relates to "productivity of texts, to how texts can transform prior texts and restructure existing conventions (genres, discourses) to generate new ones" So to say, the texts "absorb and are built out of the texts from the past." (Ibid., 102.) Fairclough (ibid., 118) distinguishes between three different kinds of intertextualities:

1. in "sequential intertextuality" different texts or discourses alternate within a text (for instance, in the case where a credit card advertisement both tells the facts about the product and attempts to sell it),

2. in "embedded intertextuality" one text or discourse type is clearly contained within the matrix of another,

3. in "mixed intertextuality" texts or discourse types are merged in a more complex and less easily separable way.

Metadiscourse is one peculiar form of manifest intertextuality. Metadiscourse implies that the person is situated above or outside his/her own discourse, and is in the position of controlling and manipulating it. Metadiscourse refers to cases where producers distinguish themselves from some level of the text, treating the distanced level as if it were another, external text. (Ibid., 122.)

Although I am not so critical, I do understand Fairclough's attempt to merge different traditions of discourse analysis. Thus, in this work, my attempt is not only to analyze 
the text, i.e. the talk of managers, carefully, but also to track its relation to wider strategy discourses regarded as social practice. I am also interested in knowing how different macro-level discourses are present in the talk of managers and how they are intertextually merged to each other. In my work, consumption is a discursive practice that mediates between the text, the discursive activity of the managers, and the social practice of strategy.

Here, I have explained my methodological choices and their background. The following question remains: How do I draw theoretical conclusions from the empirical data analyzed with the discourse analytic method? In the following, I will discuss this issue of reasoning in more detail.

\subsubsection{ARGUMENTATION: CONTEXTUAL REASONING}

Scientific reasoning refers to the process through which we draw theoretical conclusions from the data and justify them to others. Ketokivi and Mantere (2010) propose two alternative inductive reasoning strategies: "idealization" and "contextualization" (see Table 3). Idealization draws on the classical epistemic virtues of objectivity and truth. In it, inference is regarded as an autonomous process governed by normative and inter-subjective standards, while it seeks to provide normative guidelines for justifying inductive arguments. In addition to truth, Ketokivi and Mantere (ibid.) argue that the de facto epistemic virtue of the idealization strategy is actually its "empirical adequacy," the ability of the theory to produce empirical predictions. This has produced theories that are likely to be empirically valid. However, the fact that the idealization strategy separates inference from explanation is not unproblematic. By doing so, it suggests that there would be some sort of ultimate and idealized normative criteria for reasoning, which there is not. It also ignores the role of the active "reasoner," who conducts the research and makes (constructs) the arguments, and whose experience, competence and views affect the process. Theories do not emerge from the data, as is usually suggested; they are instead generated from it by the researcher, who is an active player in the reasoning process. (Ibid.) 
TABLE 3 Two REASONING RESPONSES TO THE REASONING DILEMMA (KETOKIVI \& MANTERE 2010)

\begin{tabular}{|c|c|c|}
\hline STRATEGY & IDEALIZATION & CONTEXTUALIZATION \\
\hline \multirow{2}{*}{$\begin{array}{r}\text { CHARACTERISTIC FORM } \\
\text { OF INFERENCE } \\
\text { INFERENCE AND } \\
\text { EXPLANATION }\end{array}$} & $\begin{array}{l}\text { Primary induction (eliminative, enu- } \\
\text { merative), but also deduction }\end{array}$ & $\begin{array}{l}\text { Inference to the best explanation (ab- } \\
\text { duction) }\end{array}$ \\
\hline & $\begin{array}{l}\text { Separate activities: explanation fol- } \\
\text { lows after inference has been as- } \\
\text { sessed }\end{array}$ & $\begin{array}{l}\text { Intimately intertwined, assessed si- } \\
\text { multaneously }\end{array}$ \\
\hline EPISTEMIC VIRTUE & Empirical adequacy & $\begin{array}{l}\text { Simplicity, plausibility, interesting- } \\
\text { ness, novelty }\end{array}$ \\
\hline \multirow[t]{3}{*}{ BACKING FOR WARRANTS } & $\begin{array}{l}\text { Compliance with methodological } \\
\text { idealizations }\end{array}$ & $\begin{array}{l}\text { Making personal inference transpar- } \\
\text { ent }\end{array}$ \\
\hline & & Demonstrating empirical authenticity \\
\hline & & Conservation of paradigms \\
\hline \multirow[t]{2}{*}{$\begin{array}{r}\text { ARGUMENTATION } \\
\text { STRENGHTS }\end{array}$} & $\begin{array}{l}\text { Explicit and established rules and } \\
\text { procedures }\end{array}$ & $\begin{array}{l}\text { Transparent, openly partial to the } \\
\text { explanation }\end{array}$ \\
\hline & Generalizable results & $\begin{array}{l}\text { Authentic to data and the research } \\
\text { process }\end{array}$ \\
\hline \multirow[t]{4}{*}{$\begin{array}{r}\text { CHALLENGES FOR } \\
\text { APPEALING FOR } \\
\text { WARRANTS }\end{array}$} & $\begin{array}{l}\text { Neither necessary nor sufficient to } \\
\text { describe research practice }\end{array}$ & \multirow{4}{*}{$\begin{array}{l}\text { Unpredictability due to lack of meth- } \\
\text { odological consensus about rules and } \\
\text { procedures } \\
\text { Applicability of findings } \\
\text { The challenge of subjectivism }\end{array}$} \\
\hline & May appear deceptive: idiosyncrasies & \\
\hline & of data and reasoning may appear to & \\
\hline & be intentionally concealed & \\
\hline
\end{tabular}

It is easy to acknowledge that I am not following the idealization strategy of inductive reasoning in this work. Instead, the second inductive reasoning strategy provided by Ketokivi \& Mantere (ibid.), contextualization, seems to provide more suitable strategy for me. Contextualization regards inference as a context-depended process that focuses "on arriving at what the researcher and audience judge to be the best explanation for the light of the epistemic virtues embraced" (ibid.). In practice, the contextualization strategy can mean three different things. Firstly, subjective contextualization means that the researcher's knowledge base and background affects his/her reasoning style. This calls for increased reflection from me when explaining authentically not only what I know, but how I have come to know it. Secondly, empirical contextualization provides the "reader with the maximal access to the empirical context" of the research. Here, I need to be giving examples and contextual details about my case organizations, in order to establish empirical authenticity. I need to able to describe how the empirical material was produced in them, how I analyzed the material, and how I 
drew theoretical conclusions from it. Thirdly, there is also theoretical contextualization, which means that a theory can play an important role in the reasoning process and which calls for acknowledgement of the theoretical premises and views. (Ibid.)

Having chosen the contextualization strategy of inductive reasoning means that I will not try to create nor defend my arguments based on the idealization strategy calling for generalization and predictability, but more likely, to create an interesting and novel, context-specific story, which tries to bring something new to previous strategy research. In a way, I am trying to solve the mystery of strategy consumption (cf. Alvesson \& Kärreman 2007). This might, however, include some potential challenges that Ketokivi and Mantere (ibid.) also recognize. One challenge can be excessive subjectivism and biases, the other a lack of generalization. In trying to avoid these pitfalls, I seek to contextualize my work with three different contextualization tactics: subjective, empirical and theoretical. In the following, I will describe how the research data were produced and analyzed hoping to provide an authentic account of it.

\subsection{RESEARCH DATA}

The data set, or "empirical material" (cf. Alvesson \& Kärreman 2007), of this study was produced during 2003-2008 in three case organizations (see Figure 4). Since I was personally involved in producing and creating this material in every case organization, I have decided to call this phase of the research process "production" of the data, instead of data "collection," which would suggest that the data are somehow external or unconnected to me. As a constructivist researcher, I was not a neutral or objective observer, but more likely I was involved in the data production personally and intimately myself, which calls for increased reflexivity from me. Reflexivity means justifying and explaining how I have produced, interpreted and reinterpreted the data. 


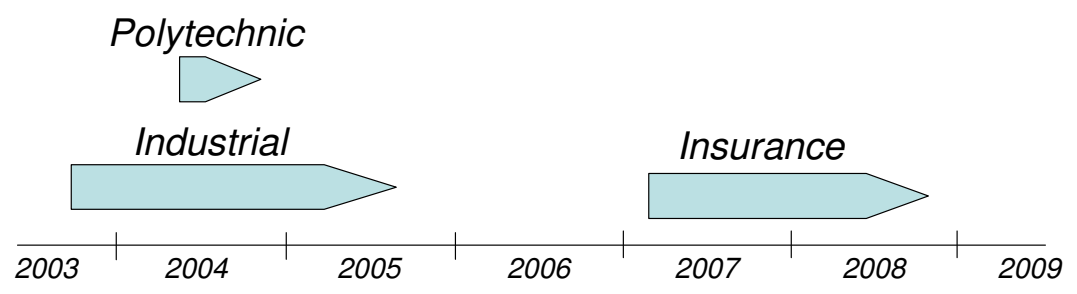

FIGURE 4 SCHEDULE OF THE DATA PRODUCTION IN THE CASE ORGANIZATIONS

At Industrial, the data were produced over a two-year period of 2003-2005; at Polytechnic, the data was produced in 2004 during the months from May to August; and at Insurance, the production of data lasted from 2007 to $2008^{10}$. These organizations were chosen as the case organizations for two reasons. Firstly, they represent different kinds of organizations in terms of their industry, organizational structure and geographical location. Industrial is a global corporation operating around the globe while having deep roots in industrial production. Polytechnic is a large public organization that has adopted the principles of the strategic management. It operates in a major Finnish city, and is a highly local operator compared with Industrial. Insurance has a rather large headquarters, while its customer operations unit has been spread across its business environment. The second reason for choosing these organizations was more pragmatic and practical by nature. I was given access to these organizations, and the data production carried out there turned out to be easy. These organizations also turned out to be original, interesting and even humorous in an interesting way, making them great contexts of consumption.

Since this study is discourse analytic by nature, the data are mostly linguistic and qualitative. They consist of interviews, written documents, web pages, observations and media coverage. The whole interview data produced in all three case organizations consists of 33 individual and group interviews (consisting of 36 interviewees), all together. The interview data were literally produced, not gathered, since due to the constructivist view, the interview situation is always a situation wherein shared reality is produced by the interviewee and the interviewer. Here, the interviewer is not an ob-

\footnotetext{
${ }^{10}$ The names of case organizations used here are fictitious originating from the case organizations' industry and nature. However, these organizations are discussed in a way that ensures that their real identities cannot be identified from this work.
} 
jective bystander or data collector in the situation, but more likely an active player, who participates in social interaction and in this way influences the construction of social reality. (Alvesson 2003.)

The talk that is analyzed linguistically in this work was produced mainly in these interviews. Each semi-structured interview took 1-2 hours and was recorded and transcribed (for the interview outlines, see Appendices 1-3) with the approval of the interviewee. The interviewing language was Finnish. The interviews at the case organizations were not conducted entirely by me, but by me and my colleagues, whom I will mention under each case organization. By using predefined questions in the interviews, it was ensured that different interviewers would ask the same questions and that the interview situations would focus on issues that relate to strategy and strategy work in particular. The case-specific interview outlines were formulated for each organization to ensure that the interviewees within every case organization were asked the same questions. There were also many similarities in the questions between the case organizations that related to the nature of the strategy concept and to the interviewee's own role in his/her organization's strategy work. In addition, at Industrial the focus was put on the company's strategy process and its functioning, and on the role of the interviewees in it. At Polytechnic, the focus was on strategy implementation with regard to a certain strategic theme and on research and development operations. And at Insurance, the interest was in strategy communication, i.e. how interviewees acted as strategy communicators and how they perceive their role.

In the interview situations, the interviewees were encouraged to share their thoughts and experiences about the issues and themes that they considered meaningful and important, whether they were included in the interview outline or not. Also, the interviewees were asked to justify and describe their ideas and views through stories and examples in order to enhance the data with narrative. All in all, an effort was made to make the interviews an interventive and confrontative arena by discussing certain issues more than once during the interviews and by encouraging the interviewees to share different and even contradictory ideas and opinions instead of emphasizing consistency (Potter \& Wetherell 1984, 164-165).

In order to increase the validity of the study, also other data sources and methods were used to create triangulation (Silverman 2006, 291-292). Observations were a major 
data source that was mainly used as background information when constructing case descriptions and analyzing the interview data. Because of the differences in the case organizations' data production processes, there is more observation data available from Industrial and Insurance than Polytechnic. Observation data helped to put the interviews into perspective and locate them contextually. Also, different organizational documents, the web sites of the case organizations, and media coverage were used as background information when constructing case descriptions and analyzing the data. In the following, I will describe the contextual factors of the data production in each organization in more detail.

\subsubsection{INDUSTRIAL ENTERPRISE}

Industrial Enterprise (henceforth Industrial), my first case organization, is a global industrial company. It produces industrial products for several customer segments and has traditionally been a product-oriented company. However, due to its newly created strategy, Industrial sought to become a market-oriented company and provide customized solutions to its customers. This represents a big strategic change for Industrial. (The more detailed description of Industrial is provided in Chapter 5.)

When the research data were produced at Industrial, the organization had just finished describing its strategy process. The new strategy process chart was pictured on a PowerPoint slide and it was supposed to ensure and enhance strategy implementation at Industrial. The strategy process chart pretty was the main artifact of strategizing at Industrial. The chart consists of two circles, the first representing strategy creation and the second strategy implementation. Traditionally, Industrial had has robust methods what it comes to strategic planning, and now, due to the new strategy process diagram, strategy implementation received more interest and resources. Many members of Industrial's top management, including the senior vice president of strategic planning, who was responsible for the strategy process, seemed to have rather high expectations for the strategy process. 
I was invited to Industrial as a researcher/consultant ${ }^{11}$ to improve the functioning of the newly described strategy process in 2003, and I was involved in the company's strategy work for more than two years. During that period, I evaluated the functioning of Industrial's strategy process and proposed improvements in it. I also facilitated a number of strategy workshops for the managers of Industrial and was allowed to observe several strategy meetings of the top management, including the two-day strategy meeting held once a year. During that time, I became a rather familiar face for the many managers and employees of Industrial, and consequently they even shared some “inside information” about Industrial's history and corporate culture with me.

At the beginning of the cooperation with Industrial, I and my senior colleague ${ }^{12}$ conducted a series of interviews with the top and middle managers of the company to evaluate the functioning of its strategy process. Ten managers were interviewed altogether that were handpicked from Industrial's top and middle managers in order to obtain a broad cross-section of managers from different parts of the company. The interview was semi-structured interview (for the interview questions, see Appendix 1); although the primary questions were selected beforehand, there was a lot of improvisation in the interview situations, and many topics outside the interview outline were raised. The dominant theme in the interviews was obviously the previously described strategy process of Industrial. However, the interviewees were also encouraged to explain how they had acted in the strategy process and how they regarded strategy in general.

The research data also consists of many official strategy and other documents of Industrial, which were given to us for background information. This information turned

\footnotetext{
${ }^{11}$ I use the term "researcher/consultant" to describe my role here. At Industrial, my aim was both to study the company's strategy process and to develop it further based on the research findings. However, at Industrial, I was known as "a researcher" from the Helsinki University of Technology. Working there with the status of researcher rather than consultant, may have provided me with more opportunity to participate in different strategy events and sessions as an observer. I had the same kind of a dual-role at Insurance. At Polytechnic, I was more like an evaluator, who evaluated the organization's strategy implementation.

${ }^{12}$ Saku Mantere
} 
out to be very valuable when describing the context of consumption at Industrial. The sources of the data are summarized in Table 4.

TABLE 4 DAta PRoduction AT INDUSTRial

\begin{aligned} DATA SOURCE & DESCRIPTION \\ \hline INTERVIEWS & $\begin{array}{l}\text { Ten interviews conducted in 2003. Interviewees were chosen from the top and } \\ \text { middle managers of Industrial from different parts of the company. }\end{array} \\$\hline DOCUMENTS & $\begin{array}{l}\text { I received several company documents concerning strategy and other subjects as } \\ \text { background information. The material was useful when describing the contextual } \\ \text { factors of Industrial. }\end{array} \\$\hline OBSERVATIONS & $\begin{array}{l}\text { I was present in various strategy workshops and seminars both as an observer and } \\ \text { a facilitator. These sessions provided me with a chance to observe how strategy } \\ \text { was communicated and consumed by the managers of Industrial. }\end{array}\end{aligned}$

As described previously, my role at Industrial was anything but that of an objective bystander or observant. I was deeply involved in the company's strategy work for more than two years, with the aim of developing and enhancing its performance. This almost made me an insider in its strategy process. This fact may be both a strength and a weakness concerning this study. The fact that I was involved in the strategy process may have given me some crucial information that enabled me to deepen my analysis and understanding of Industrial's strategy consumption. Getting to know many managers of Industrial fairly well may have given me a closer look at their personal style of strategy consumption. However, this closeness might also have made me biased to some extent, since at the time the data were produced I was a rather young and inexperienced $\mathrm{PhD}$ student, who might have been particularly open to the influence of the experienced managers of Industrial.

\subsubsection{PolyteChNiC}

The second case organization, Polytechnic, is a Finnish multi-sector polytechnic. Polytechnic provides education to thousands of students in three faculties that are further divided into a dozen degree programs. Although Polytechnic operates under a City Council and the Ministry of Education, it has autonomy in its internal affairs and it is managed by a board and a rector. At the time the data were produced at Polytechnic, the organization was implementing its strategy. A special effort was put on the 
strategic theme called " $R \& D$ operations," which aimed to increase the amount of Polytechnic's research and development conducted in cooperation with its external stakeholders. The motivation for promoting the R\&D at Polytechnic was both internal and external. Due to previous changes in the Finnish legislation, the polytechnics were obligated to engage in R\&D. However, Polytechnic also considered that the successful R\&D would legitimize its activities and improve its brand. This attempt to pursue $R \& D$ represented a big change at Polytechnic, especially for those who were supposed to engage in $R \& D$ along with their teaching duties. (For the more detailed case description of Polytechnic, see Chapter 6.)

I and my colleague ${ }^{13}$ conducted an evaluation study of strategy implementation at Polytechnic. For the study, we interviewed two top managers, six middle managers, one support function manager, and twelve teachers at Polytechnic that were chosen at random from among the three personnel groups of the organization (top management, middle management, and personnel). The top managers and the support function manager were interviewed individually while the middle managers were interviewed in pairs. $R \& D$ was chosen as a strategic theme that we tracked at different levels of the organization. Because the emphasis in this work is on the managers, the interviews with the employees (teachers) were excluded from this work, and the interviews with the top and middle managers have been used as the main interview data in the study.

The interview outlines used for the top and middle managers were slightly different (see Appendix 2). Also, the interviewees were asked in the interview situations to fill out two questionnaires that asked how they had contributed to promotion of R\&D operations and what problems they connected with strategy implementation at Polytechnic. Although the numerical data received from these questionnaires were not used in the study, sequences where the managers thought aloud about their answers to these questions are included in the interviews and have thus been used as data.

As background information, we received several documents from Polytechnic that discussed its organizational structure and strategy work in general. I have used these documents to contextualize the interviews and to construct Polytechnic's case descrip-

\footnotetext{
${ }^{13}$ Jouni Sipponen
} 
tion. Also, Polytechnic's website proved useful in the analysis. It provided me with access to old annual reports of Polytechnic, which gave me important background information on the organization and its history. All data sources are summarized in Table 5 .

TABle 5 DAta PROduction AT Polytechnic

\section{DATA SOURCE DESCRIPTION}

INTERVIEWS Six interviews (three individual and three pair interviews, a total of nine interviewees) were conducted in 2004. The interviewees were chosen from the top and middle managers of Polytechnic from different parts of the organization.

DOCUMENTS Different documents and web pages of the organization were used as background information in constructing the case description and analyzing the data.

WEB PAGES I used Polytechnic's websites and old annual reports as a source of background information in constructing the case description of it.

My role as a researcher was different at Polytechnic from that at Industrial. I was not deeply involved in the strategy work at Polytechnic, except for conducting an evaluation study and presenting its results once at a management board meeting. I was more like an outsider who was invited to the organization to evaluate the functioning and state of its strategy process. After that assignment, I have had no further contact with Polytechnic nor have I worked for it in anyway. After the evaluation study conducted in 2005, Polytechnic has undergone further major changes by merging with another polytechnic. Polytechnic, as such, does not exist any longer, since the merger changed its structures, management, and name.

\subsubsection{INSURANCE COMPANY}

Insurance company (henceforth Insurance) is a Finnish service organization that provides insurance services to its customers in different customer segments. These services are produced at the headquarters of Insurance by the business units, and the market operations like marketing, selling and customer service, performed by the customer service organization spread across the business area. Insurance has a long history in the business, and actually its current organization form is a result of rather many mergers and acquisition over the years. Insurance has a strong strategic intent of being a customer driven company. It also has a developed strategy process, which 
governs and guides the strategy work done in the company. Recently, Insurance has pursued strategy communication extensively, emphasizing that every employee should understand and adopt its strategic intent and realize it in his/her everyday work. (For a more detailed case description of Insurance, see Chapter 7.)

As in the case of Industrial, I was involved at Insurance as a researcher/consultant to improve its strategy work, especially strategy communication with regard to line and middle managers. For a period of two years, I was involved in Insurance's strategy work in many ways. At the beginning, I conducted a preliminary interview study with my colleagues ${ }^{14}$ in order to evaluate the state of strategy communication at Insurance. Based on the results, we made suggestions on how to improve strategy communication at Insurance. I also hosted a number of strategy communication workshops for the managers of Insurance with my colleagues, to improve and enhance their strategy communication skills. We provided them with some new communication tools and methods that they could later use in their own work in discussing strategy with their own employees. I was also provided an access to observe several strategy meetings at Insurance.

At the beginning of our collaboration with Insurance, we interviewed 18 managers of Insurance to find out how they considered their role as strategy communicators. The interviewees were handpicked from two business units and from the customer service organization of Insurance, six managers from each unit altogether. We tried to pick interviewees from different organizational levels so that there would be variance in the data. As at Industrial and Polytechnic, the interviews were semi-structured (for the interview outline, see Appendix 3) and the managers were asked to describe their own role and activities with regard to strategy communication. These interviews are the main source of data for Insurance in this work.

As at Industrial, I was provided with an access to observe, host and facilitate a number of different strategy workshops and sessions for the managers of Insurance. These events provided me with an interesting chance to make observations concerning Insurance's strategy work and to better understand Insurance's organizational culture.

\footnotetext{
${ }^{14}$ Katriina Karkulehto and Kaisa-Riikka Salomaa
} 
These observations, along with the documents received from Insurance, helped me contextualize the interviews and construct the case description. During different training events, I also had many informal conversations with different people of Insurance that increased my understanding of the company's strategy work. During the almost two year co-operation project with Insurance, I also discussed and pondered many issues related to the company with my colleagues. This mutual sensemaking has obviously affected my view of the company. The sources of the data are summarized in Table 6.

TABLE 6 DATA PRODUCTION AT INSURANCE

\begin{aligned} DATA SOURCE & DESCRIPTION \\ \hline INTERVIEWS & $\begin{array}{l}18 \text { interviews conducted in 2007. The interviewees were chosen from the top and } \\ \text { middle managers of Insurance in three different units. }\end{array} \\$\hline DOCUMENTS & $\begin{array}{l}\text { Several documents received from the company helped me construct the case de- } \\ \text { scription of Insurance and contextualize the interviews. }\end{array} \\$\hline OBSERVATIONS & $\begin{array}{l}\text { I was present in various strategy workshops and seminars both as an observer and a } \\ \text { facilitator. These observations provided me with a more thorough understanding of }\end{array} \\ &$ Insurance's organizational culture. \end{aligned}

At Insurance, my role as a researcher was similar to that at Industrial. I was engaged in the company for almost two years as a researcher/consultant with the aim of studying and improving its strategy communication practices. The people with whom I worked at Insurance were exceptionally warm and friendly to me during our cooperation, which may have influenced the way I perceive Insurance and its organizational culture. However, in this case I consider myself to be more experienced than in the case of Industrial, which is why my observations and findings concerning Insurance may be more accurate and mature.

\subsection{ANALYSIS}

The analysis process of this study has been anything but a straightforward effort. There have been some real ups and downs along the way, and I have literally muddled through the data for years. The process included four stages (see Table 7). The analysis process began with confusion: I made various starts in trying to make sense of the 
data. Most of them did not succeed. As a result, however, I became rather close and familiar with my empirical material, and at some point during the analysis, I came up with the idea of the macro-discourses of strategy. Next, I was being introduced to de Certeau by my instructor, whose writings gave me the idea of consumption. This provided me with a lens to analyze the data in greater depth. Finally, I came up with a framework that captures the process of strategy consumption as a whole.

TABLE 7 ANALYSES PROCESS

\begin{tabular}{|c|c|}
\hline Stage & DESCRIPTION \\
\hline $\begin{array}{r}\text { FIRST STAGE: } \\
\text { GETTING TO KNOW } \\
\text { THE DATA }\end{array}$ & $\begin{array}{l}\text { I took two false starts when analyzing the data: strategic learning and strategy } \\
\text { implementation. The stage did not produce any concrete outcomes but allowed } \\
\text { me to become rather familiar with the research data. }\end{array}$ \\
\hline $\begin{array}{r}\text { SECOND STAGE: } \\
\text { MACRO-DISCOURSES }\end{array}$ & $\begin{array}{l}\text { Managers seemed to draw on the larger discourses and isms when talking } \\
\text { about strategy and its ideals. At this stage, I coded this kind of talk and con- } \\
\text { structed five macro-discourses of strategy. These macro-discourses are milita- } \\
\text { rism, mechanism, humanism, pragmatism and spirituality. }\end{array}$ \\
\hline $\begin{array}{l}\text { THIRD STAGE: } \\
\text { CONSUMPTION }\end{array}$ & $\begin{array}{l}\text { At this phase, de Certeau's term consumption provided me with a theoretical } \\
\text { lens to analyze managers' accounts of how they consume and use strategy in } \\
\text { their talk. I came up with two discursive practices the (re)production and us- } \\
\text { age and three different usage tactics, instrumental, playful and intimate, to } \\
\text { illustrate and describe strategy consumption. }\end{array}$ \\
\hline $\begin{array}{l}\text { FOURTH STAGE: } \\
\text { FRAMEWORK }\end{array}$ & $\begin{array}{l}\text { Finally, I produced a framework that describes the strategy consumption proc- } \\
\text { ess as a whole. The framework helped me to conceptualize and portray strat- } \\
\text { egy consumption in the case organizations and in general. }\end{array}$ \\
\hline
\end{tabular}

However, in reality the various stages of the process were much more overlapping and simultaneous than a description like this can ever portray. In the following, I will describe and reflect the journey of analyzing the data, which turned out to be a personal learning process.

\subsubsection{FiRST STAGE: GeTTING TO KNOW THE DATA}

After being accepted as a PhD student in 2004, I took at least two, more or less, serious attempts to analyze my data. Both turned out to be "false starts" (Potter \& Wetherell 1984, 168). Next, I will describe what these attempts were, why they did not succeed and what I learned from them, with respect to the current research interest. Although neither of these starts took me far with my research, they laid the 
ground for further ideas. As a result, I became rather familiar with the research data and to some extent they seemed to be necessary in order to get the work started.

When I first started to do my $\mathrm{PhD}$ dissertation, I was interested in studying strategic learning, the process of strategic renewal and development of an organization. Since strategic learning is a highly abstract issue, I decided to approach the data produced at Industrial and Polytechnic from the deductive viewpoint. I applied two widely acknowledged distinctions in the field of strategy as frames, in order to track different rhetorical strategies (discourses) related to strategic learning. The first frame was the distinction between organizational learning as exploration and as exploitation (March 1991; Crossnan, Lane \& White 1999; Crossnan \& Berdrow 2003), and the second frame was the distinction between sensemaking and sensegiving (Gioia \& Chittipeddi 1991). Although finding the subject highly interesting and tempting in many ways, I found it really hard, when applied to my data. After several attempts to analyze the data, I decided to give up.

After dropping the idea of studying strategic learning, I turned my attention to strategy implementation since it seemed to represent an important theme in the data. Although strategy implementation has been studied from multiple angles, e.g., in terms of tactics and models (Nutt 1986; Bourgeois \& Brodwin 1984) and activities (Aaltonen 2007), little is known about the language of strategy implementation, and my intention was to focus on this angle. More precisely, I was interested in studying what is actually constructed as strategy implementation in the talk of top and middle managers and how strategy implementation is constructed discursively. I was also interested in finding out what kinds of discursive practices are related to it and what kinds of subject positions are embedded in the strategy implementation discourse.

Perhaps the study of strategy implementation did neither succeed because the entire concept of strategy implementation is in a way based on the rational strategy approach. It draws on the rather mechanical idea of separating planning and formulating. Connecting this kind of a rational ethos to the discourse analytic research tradition turned out to be an impossible task for me, which is why I never got far with it. However, while reading the data over and over again, I came across a certain pattern that I found interesting, that is, the macro-discourses of strategy that the managers seemed 
to use as resources (cf. Fairclough 1992, 84-86) when constructing strategy and their role in it. This finding turned out to be important for my dissertation.

\subsubsection{SECOND STAGE: MACRO-DISCOURSES}

While struggling with the data of mine, I found out that broadly speaking, the managers seem to discuss strategy work at two different levels. Firstly, they construct accounts describing both their own and their organization's current activities with regard to strategy. Secondly, they described the desired or ideal state of strategy, which describes how they would like to act in strategy work and what strategy should be in an ideal world. This category of talk attracted my attention and I started to analyze it more carefully.

I coded the data and categorized it in terms of the differences, similarities and patterns that could be found in it (Potter \& Wetherell 1984, 168). By drawing on Fairclough's (1992, 64) three different aspects of the constructive effects of discourse, I constructed categories by asking a) how the talk constructs the systems of knowledge and beliefs in the case of strategy, i.e. what strategy is according to it, and b) how it is practiced. I was also interested in finding out c) how talk constructs social identities and subject positions, and d) how it produces social relationships between people. I soon noticed that different categories of talk contained features of the isms like humanism and rationalism, and even religion, and they were used both as means and causes when the managers tried to build their point of view. They appeared to be resources by nature that were being drawn upon (ibid., 85-86).

As a result of the coding, I came up with different categories of talk that seemed to have their own special characteristics. I decided to call these categories of talk macrodiscourses of strategy, since they construct strategy as a universal phenomenon by drawing on broad societal discourses and isms (cf. Alvesson \& Kärreman 2000b). There appeared to be five such macro-discourses.

The militaristic macro-discourse brings strategy back to its ancient roots and seasons strategy with war rhetoric. The business environment is viewed as a "battlefield," managers are "generals," and strategy is a military plan or projection that guided the actions of organizational members, who are "soldiers." The mechanistic discourse 
views strategy as a posture: a position, scope, or plan that needs to be implemented in an effective manner as such. It outlines the role of "systems" and "mechanisms" in strategy work. The humanistic macro-discourse differs from the mechanistic and militaristic discourses in many ways. It stresses the voluntaristic nature of humankind and outlines the importance of "participation" and "meaningfulness" in strategy work. It raises humans to the status of willing and mindful actors who are at the center of any organizational action. The pragmatic discourse highlights the significance of "concreteness" and "practicality" in strategy work. The pragmatic discourse considers strategy a part of the "everyday activities" of the organization and managers; in some cases it even says that strategy is action per se. The spiritual discourse draws on religious rhetoric, connecting strategy to a spiritual experience and/or practice. It assumes that "faith" and the experience of it are both the preconditions and antecedents of strategy. Strategy is a practice that gives people "mission" and "vision" and connects them with the higher level purposes of the organization, giving them a sense of belonging. (The macro-discourses are discussed more thoroughly in Chapter 4.1.)

At some point in the analysis, there was also a sixth macro-discourse called consumerist that attached strategy to the rhetoric of commerce and trade. Here strategy was a consumer good, an idea or ideology that is "bought" and "sold" by members of the organization who are considered consumers or clients. However, while analyzing the data more thoroughly, somehow this discourse did not seem to be able to stand on its own feet and I decided to abandon it and merge it with other macro-discourses, mainly with the pragmatic, humanistic and spiritual discourses. ${ }^{15}$

\subsubsection{THIRD STAGE: CONSUMPTION}

After having constructed the macro-discourses of strategy, I wondered what to do with them and how to proceed with the analysis. My previous attempt to analyze strategy implementation had been made without any predefined theoretical frame-

\footnotetext{
${ }^{15}$ I also chose to abandon the discourse because I became interested in de Certeau's idea of consumption. I thought that the consumerist macro-discourse would confuse the reader at some point.
} 
work, excluding the discourse analytic methodology ${ }^{16}$. This may have been the reason why I was unable to find a meaningful pattern in the data that would have satisfied me. It became clear that in order to make a sound theoretical contribution of the kind required for a dissertation, some sort of framework was needed to take the analysis a step further.

At that time, I came across Michel de Certeau's book The Practice of Everyday Life (1988) and it soon proved to be a turning point for my research process. It changed and renewed my thoughts and gave the work a new course. When reading and digesting de Certeau's thoughts about subjectivity and human agency, and reading the research data, I soon noticed soon that, indeed, managers consume and use strategy in their talk creatively - and even humorously. The managers were not just describing their role and activities in strategy work in general, but also using strategy for their own purposes. I became inspired by these findings, which opened up new horizons for my research.

De Certeau's term “consumption” provided me with a theoretical lens through which I could take the analyses to a deeper and more meaningful level (cf. theoretical contextualization, Ketokivi \& Mantere 2010). The idea of consumption also suited my own thinking and ideology about human nature and made sense to me immediately. The structural idea that humans are entirely subject to the structures was too restricting and pessimistic from my perspective, which is why I was eager to adopt de Certeau's ideas. In a way, de Certeau's thinking provided me with “redemption” (cf. Mitchell 2007) in terms of both my research process and theoretical thinking.

At this phase of the analyzing process, I started to read the data in order to figure out how the consumption of strategy is expressed in the talk of the managers. Here, I soon realized that there are (at least) two levels or categories of talk that constitute the art and practice of strategy consumption. De La Ville and Mounoud's $(2003,108)$ idea that strategy consumption is something that includes both the production and use of

\footnotetext{
${ }^{16}$ Of course, it is obvious that everything I had read before had influenced and channeled the analyzing process, but at that point I did not have any theoretical idea through which I could have read the data and analyzed it systematically.
} 
strategy confirmed my findings at this point. Likewise, I noticed that there is talk that does not particularly use or apply strategy, but more likely grounds and generates the whole idea of strategy for the further use of it. In this category, the managers define strategy at the societal level, adapting it to their own organizations here and there. I decided to call this category the (re)production of strategy. Secondly, there is an overlapping category that literally uses and plies strategy for the user's own purposes and ends and I eventually decided to call this category as the usage of strategy.

At this point, I struggled quite a long time in thinking what the two categories of talk, (re)production and usage, are in terms of their ontology. I pondered different ideas, starting from narratives and ending with genres until Fairclough's $(1992,73)$ thinking gave me a simple answer. They are discursive practices that are used when consuming strategy. In the following, I will describe these two overlapping and interlaced discursive practices in more detail.

\section{(RE)PRODUCTION}

The first discursive practice of the strategy consumption process, (re)production, recognizes and discusses strategy and strategy work ideals peculiar for the case organization, with help of the macro-discourses of strategy. Similarly, it generates and grounds strategy as a management discipline. It brings strategy into being and produces meaning for it for the further usage (Fiske 1989, 35). The managers (re)produce strategy as a general management discipline at both the societal and organizational level. The following quotes are examples of the (re)production, one from each case organization:

"It [strategy] is such a big collective desired state and outlook, collective outlook of how the company can succeed."

"I actually read the strategy as a sort of shared contract here within the polytechnic.”

"That it [strategy] would be taken to as concrete level as possible, so that the individual seller understands what this means 'in my life'. [...] This is everyone's thing."

The previous comments from the managers illustrate the (re)production of strategy. All of them define and describe what strategy is, or what it should be. I categorized 
talk like this from the data and decided to call it (re)production, since it clearly (re)produced and maintained the discipline of strategy. However, I was interested in knowing how strategy was (re)produced, i.e. what the managers said it was. That is why I analyzed the (re)production of strategy more carefully under each case organization, to identify its different flavors and sub-categories.

The case-specific analyses of the (re)production showed that (re)production constitutes much of the talk that describes the official strategy process peculiar to each case organization. So, it was de facto not about the actual usage of strategy, but more likely about its construction and production at general and organizational levels. Anyway, once this introduction and (re)production of strategy has been done, strategy is used for the purposes of the consumer(s) in question. Then strategy is no longer a distinct phenomenon, but something that the managers use themselves; they make something out of it. Here, the usage of strategy takes the form of tactics that are manifestations of it. Each tactic has its own flavor and purpose.

\section{USAGE TACTICS: INSTRUMENTAL, PlAyFUL, INTIMATE}

As de Certeau (1988, xx) brings out, consumption is manifested through the consumption tactics that are rhetorical by their nature. Keeping this in mind, I returned to the data and started to analyze what kinds of usage tactics managers seem to use when consuming strategy in their talk. This phase of the analyzing process became somewhat challenging, since the consumption of this kind is clandestine (de Certeau 1988, 31) and tacit by nature and somehow hidden within the "official" strategy discourse.

At first, I read the data as a whole with the aim of identifying some general patterns of strategy use. While reading the data, I noticed that there seemed to be roughly speaking three kinds of talk about strategy that each seemed to fulfill its own function and purpose (cf. Potter \& Wetherell 1984, 168). Firstly, there was a talk that constructs strategy as a device, something that is used as a tool or method in strategy work to gain something. The following comment from the manager of Insurance is an example of this kind of talk:

"Especially, if an employee criticizes why something has to be done, 'this kind of strange thing', I'll bring out the strategy angle or say that this is related to this 
part of the strategy [...] For me, it [strategy] is justifications and support for the thing that I take further."

Here, the manager clearly states that strategy provides him/her with "justifications and support" in different situations, for instance when his/her employee questions a decision that has been made. In cases like this, strategy is clearly a means to do something for the manager. I decided to call this tactic instrumental. Secondly, there was a talk that takes a rather ironical and critical stance against strategy and sort of plays with it. The following extract shows how the manager of Insurance plays with strategy:

"When the new employees arrive and when the new strategy period begins, a sort of strategy booklet is delivered to every employee [of Insurance]. It was like Mao's Red Book.”

This kind of talk differs clearly from the instrumental tactic. Here, strategy is not taken too seriously. First, I decided to call this tactic ironic because it included rather much ironical and satirical talk about strategy. However, when I realized that irony is created when the spoken words are intended or understood to mean the opposite of what is literally stated (Hatch 1997), I understood that it would be a too limited term to describe and illustrate the whole tactic. Then, I decided to call this tactic playful, as De la Ville and Mounoud (2003, 105) do in describing the nature of consumption. Thirdly, there was talk that constructs strategy as a personal experience or issue for the managers. In the following example, a manager from Industrial emphasizes his/her personal relationship to strategy:

"I have never bought the strategy; neither shall I buy it today."

The manager has "never bought strategy," meaning that he/she does not approve or adopt it on purpose. This kind of talk constructs strategy as an intimate phenomenon, something that describes a manager's personal relationship to strategy. Here, managers give accounts on how strategy affects them and how they understand it. I decided to call this tactic intimate.

After producing these three usage tactics at the general level, I started to analyze how they were manifested at the level of the individual managers in different case organizations. To do this, I read the individual interviews again, one-by-one, beginning with 
the case of Industrial. Under each interview, I recalled how the manager constructed strategy as a general phenomenon (reproduction) and, especially, how he/she uses and consumes it in his/her own work. In other words, I tried to understand what the managers make out of the strategy in their talk. I applied the three usage tactics described previously as a template in this phase of the analysis, and tried to figure out how they were manifested in the case of each individual manager. Here, I also evaluated how the tactics fit into the data in order to validate them. Based on each interview, I wrote short mini-narratives that described who the manager was, what strategy was for him/her, and how he/she used it in his/her work. Especially, I tried to analyze how the three usage tactics were manifested in the talk of managers and how the managers used the macro-discourses of strategy as their resources.

\subsubsection{FOURTH STAGE: FRAMEWORK}

At the end of the day, I had three different elements of strategy consumption at hand. At this point of the analyzing process, I found out that I need to categorize these elements in a certain manner to make sense of all this, and to be able to describe how these different phases of the process relate to each other. Here, John Fiske's book Understanding the Popular Culture $(1989,36)$ increased my understanding of the practice of consumption. His idea that popular culture, as a form of consumption, is "an art of being in between" the dominant structures and their use, helped me to understand that strategy consumption is also something that happens between " $u s$ and them."

Having this in mind, I started to consider the two extremes mediated by consumption. Obviously, the structure here is the discipline of strategic management that is manifested in the form of macro-discourses of strategy. These macro-discourses represent structures that the managers, as users, use when consuming strategy. Here, the term "poaching," brought up by de Certeau (1988, 31), and used by De la Ville and Mounoud (2003, 109), enters the picture. Consumption is an activity that uses strategy for the purposes of an individual with different functions (instrumental, playful and intimate). The macro-discourses of strategy, on the other hand, are used as resources in this consumption process. This usage is poaching by nature, since it borrows and hunts these larger discursive entities to build one's own point of view (ibid.). So, the 
two discursive practices of strategy consumption poach the macro-discourses of strategy in subtle and creative ways.

So, in terms of my own work, strategy consumption is something that happens in between the dominant strategy discourse and managers' own use of it. Consumption is a mediating factor between structure and subject. As identified before, the strategy consumption process, or the trajectory, as de Certeau would call it, includes two sides (see Figure 5). Firstly, managers consume strategy by (re)producing it with the help of the macro-discourses of strategy. The (re)production of strategy brings strategy into being by constructing it as management discipline. Secondly, the managers use strategy tactically for their own purposes through three different tactics (instrumental, playful, intimate). The consumer performing this process is an individual manager located in particular local discursive context. In order to understand strategy consumption, this context has to be taken into account, since the talk does not exist in a vacuum. The primary local context of consumption, wherein the manager operates, is his/her own organization, which is taken under consideration in this work. However, it has to be noted that the manager also operates in a wider social context that extends beyond the limits of a particular organization. This is the context that hosts the macrodiscourses of strategy that are imported into the case organizations for strategy consumption.

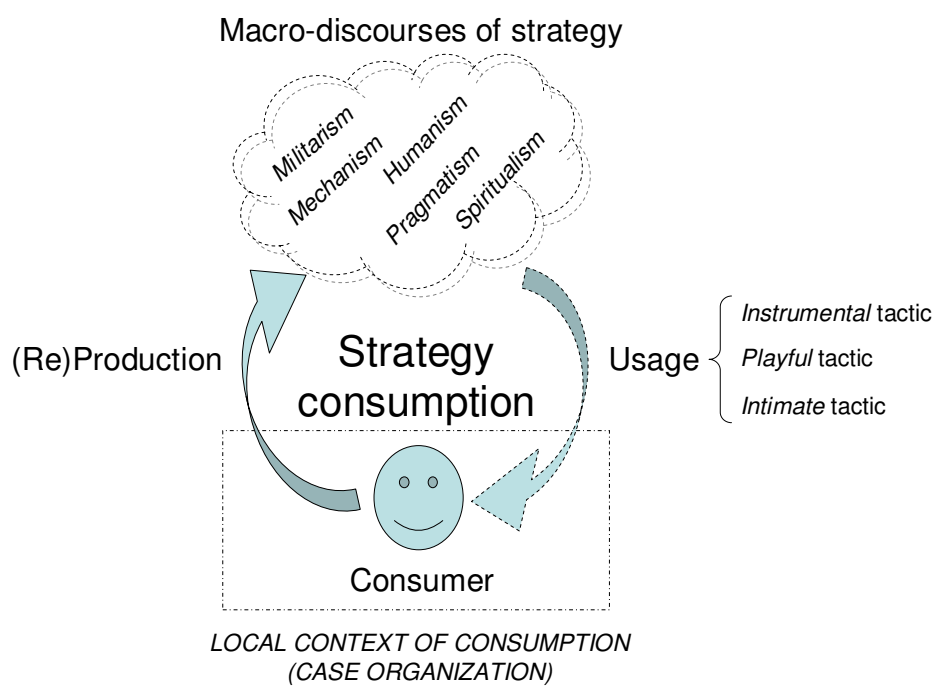

FIGURE 5 STRATEGY CONSUMPTION PROCESS 
The framework also fits Fairclough's $(1992,73)$ three dimensional conception of discourse nicely. The macro-discourses represent the social practice of strategy while the (re)production and usage are discursive practices. Here text is considered as the discursive activity of the managers (Fairclough 2005) that are poets of their actions, in the midst of the strategy discourse. In my view, the different elements of the strategy consumption process (macro-discourses, (re)production, and usage) are collective by nature. That is, they are shared categories of talk, although they consist of different kinds of variations and styles that are further illustrated in detail in this work.

After constructing the framework and writing the case-specific results, I asked my colleagues ${ }^{17}$, with whom I had produced the data in the case organizations, to read my framework for strategy consumption and the case-specific results, in order to evaluate the validity and "correctness" of my interpretations and constructions. Although a constructivist study like this is always a construction of the researcher, who is an author of his/her work, I decided to do this checking, in order to ensure that the "facts" presented in the case descriptions are correct, and to get feedback on my analysis. This could also be read as a means to increase the validity of the results (Potter \& Wetherell 1984, 169-171). As a result of this review, my three colleagues gave their feedback and suggestions for minor revision that I implemented in the text.

As discussed earlier, consumption is an activity that uses strategy to adapt it to its own interest and rules (de Certeau 1988). In this chapter, I have showed how I have set out to study it in this work by discussing the premises of my research methodology, describing the production of the research data, and reasoning how I have analyzed it. The following four chapters present the results of this study.

\footnotetext{
${ }^{17}$ Saku Mantere (Industrial), Jouni Sipponen (Polytechnic) and Katriina Karkulehto (Insurance)
} 


\section{ELEMENTS OF STRATEGY CONSUMPTION}

In this chapter, I will discuss the elements of the strategy consumption process described in the previous chapter. Firstly, I will discuss the macro-discourses of strategy that managers use as resources when consuming strategy. After that, I will elucidate and introduce the tactics of strategy usage, that is, the micro-level ways in which managers consume and use these macro-discourses in their talk.

\subsection{MACRO-DISCOURSES OF STRATEGY}

Macro-discourses of strategy are discursive resources; they are macro-level structures that are used in strategy consumption. Since they are called macro-level discourses, means they are not only present in the case organizations, but also exist in the sphere of culture of a larger management and strategy discourse. They are derived from the social context of strategy (Fairclough 1992, 73) used and maintained by different strategy practitioners of the strategy community. In this respect, they are "imported" to the case organizations from outside (Phillips et al. 2008, 782). Managers use and poach these macro-discourses in both the (re)production and usage of strategy.

All five macro-discourses presented in this chapter discuss the nature, conditions, and actors of strategy and they are present in all three case organizations, although some of them are of course more dominant than the others. In a sense, all of them are ideal discourses because they portray strategy as it should be in an ideal state. I will discuss under each macro-discourse a) how they construct the practice of strategy, i.e. how strategy is done according to them, b) what subject positions they produce for different actors in strategy and c) how these different subject positions are related to each 
other. (Cf. Fairclough 1992, 85-86.) The macro-discourses are the following: 1) militarism, 2) mechanism, 3) humanism, 4) pragmatism, and 5) spiritualism.

\subsubsection{MILITARISM: DISCOURSE OF WAR AND COMMANDING}

The militaristic macro-discourse brings strategy back to its ancient roots by seasoning strategy with war rhetoric. The following comments from the managers of the case organizations illustrate the nature of the militaristic macro-discourse:

"The execution [of strategy] is like the Finnish offensive against the Soviet Union in the Second World War. It was the boys in the front line who shot the enemies, not the generals."

"The role of the unit manager is to see [...] the battlefield. And sometimes you need to give resources to pioneers so that they can go and build the bridge there beforehand; otherwise we can't across the river."

$"[\ldots]$ the boys will go around the Eastern Europe market area [...] those front line fellows will start to pull the trigger."

The militaristic macro-discourse paints a rather violent and warlike picture of strategy. Accordingly, strategy is a bloody business, practiced through the principles and ideals of the military. The discourse portrays strategy as a "war plan" or projection that guides the actions of organizational members. Strategy aims at winning battles or killing enemies, while a business environment is viewed as the "battlefield," and managers as ones capable of seeing the whole battlefield. The organization is seen to be in a constant battle against its environment and competitors, who are referred to as "enemies."

The militaristic discourse also glorifies managers, stressing their role as commanders of their troops. It clearly positions them as the officers, who are not just highly capable but also legitimized to give orders to people executing the strategy orders. Strategy is executed through the commands and orders given by these "generals" or “commanders." The employees, considered as "troops" or "soldiers," are responsible for executing these orders obediently, while fighting on the "front line." Besides that, the militaristic discourse is also very masculine by nature. Soldiers are considered "boys" and the generals and commanders most likely as men. 
The militaristic discourse sees humans as rather mechanistic and rational actors. The discourse more or less separates the thinkers and doers, planners and implementers of strategy. The chain of command is very top-down, leaving little, if any, room for improvisation at lower levels of the organization. In this respect, the militaristic macrodiscourse has its roots in the rational strategy approach in various ways. The discourse is also close to what Mantere and Vaara (2008) call a "disciplining discourse" that reproduces and maintains certain organizational hierarchies and command structures in strategy process and organizational decision-making. The discursive strategy research has also identified the militaristic roots of the strategy discourse before. Knights and Morgan (1995) emphasize how strategy, before entering the business community, was predominantly connected to the military, where it provided professional officers a means to scare resources, legitimize their exercise of power and sustain their privileged status and prestige. The militaristic macro-discourse reflects these ideas rather closely.

\subsubsection{MECHANISM: DISCOURSE OF PROCEDURES AND SYSTEMS}

Like the militaristic discourse above, the mechanistic discourse constructs strategy as a posture: a "position," "set of targets," or "plan" that is designed or planned by the top managers of the organization. However, the mechanistic discourse draws on the mechanical rhetoric, constructing organization as a machine that executes strategy accurately.

The following quotes illustrate the mechanistic discourse in more detail:

"We set the targets for them in our steering team and they cascade to different areas and to every fellow himself."

"Strategy will be then driven downwards."

"It's like implementing the strategy given from above to the practical people. That's it."

"But then, we've had a pretty consistent strategy implementation process."

"Here, when they control these [business units], it is top-down action, guarding and controlling." 
"The inputs of the process are the changes in the business environment. And the output should be that at the individual level things are done [according to it]. The leadtime of this thing [strategy process] should be short and efficient, just like any other process."

The mechanistic macro-discourse explains little of the content of strategy, but discusses the processes and mechanisms through which strategy is (or should be) accomplished in the organization. According to the mechanistic discourse, the strategy process is a one-way, mainly a top-down process, where strategy "cascades" downward through different organizational levels and layers. The discourse includes many discursive practices that highlight this vertical dimension and nature of strategy. Strategies are made on the "top" of the organization, and they are "implemented" to "practical people" at the lower levels of the organization. After the strategic objectives are set, they "cascade" downwards in the organization. In the mechanistic discourse such strategy implementation is described with metaphors like "rolling out" and "cascading." These expressions show how strategy implementation is regarded as a goalsetting process wherein a grand strategy is divided into sub goals and targets. These procedures and mechanisms are designed and set by the top management.

While the militaristic macro-discourse positioned managers as central players in the strategy, the mechanistic macro-discourse outlines the role of systems and mechanisms in strategy. However, the discourse views implementers of strategy as parts of the machine, passive recipients of strategy, who are capable, motivated and willing to implement strategy when provided with sufficient objectives and targets through the mechanisms. They are given "inputs," and certain "outputs" are expected. Like the militaristic discourse, the mechanistic discourse leaves little, if any, room for improvisation or application. It assumes that strategy should be implemented as such, and behavior and organizational structures should be changed according to it. In some cases the mechanistic discourse even says that people should be "forced" to implement strategy.

The mechanistic macro-discourse has the elements of the "technologization discourse" (Mantere \& Vaara 2008). In it, strategy work is linked to concrete technologies, and strategy processes are driven by specific systems, which set the rules to be followed. These procedures are usually constructed and defined by top managers, 
while organizational members are to follow them. This kind of Foucauldian panopticon usually legitimizes certain mechanisms and technologies and makes them an end in themselves. (Ibid.)

\subsubsection{HUMANISM: DISCOURSE OF PARTICIPATION AND COMMITMENT}

The humanistic macro-discourse is in many ways different from the militaristic and mechanistic macro-discourses discussed above. The humanistic discourse stresses the importance of participation and the significance of the entire personnel in strategy work. It places humans, as willing and thoughtful actors, at the center of strategy work at the every level of organization.

The following comments are manifestations of the humanistic discourse:

\footnotetext{
"My idea was to involve a lot of people in strategy so there would be commitment."

"When shared strategies are agreed, people should be involved in them and in that way they would also commit themselves to them."

"Understanding is a different thing from acting according to it. In the strategy [documents], the phrases have been written in plain Finnish [...] Certainly everyone understands them, but do they feel that it's important for me?"

"I think the creation of competence strategies and their synchronization will enable us to have a constructing dialogue and in that way we can find the shared outlook. [...] Strategy won't work if the people feel that it has been given [to them] from outside."
}

The humanistic discourse stresses the voluntaristic nature of humankind. It claims that people cannot be forced to follow strategy of any kind, without their consent. The discourse emphasizes the role of "participation" as a precondition for a successful strategy process. It assumes that when people at different levels of the organization are allowed to "participate" in the strategic planning, they will also "commit" themselves to the strategy implementation. And on the contrary, if people are excluded from the strategy creation process, they are unlikely to feel "ownership" for the strategy, which distances them from it. 
The discourse of humanism also brings up "meaningfulness" as a condition of successful strategy implementation. The more meaningful people find strategy, the more willing they are to act according to it. The humanistic discourse does not make a strong distinction between different actors in strategy. Instead, it is more likely to suggest that all members of the organization have an important role in strategy, and that strategy should belong to everyone in the organization. It says that strategy is a common issue "shared" by the members of an organization. Strategies are not commands given by top management, but are instead like agreed and fixed "contracts" that are guide the coherent and consistent action of the organizational members.

This kind of a discourse, emphasizing dialogue between different groups in organizations and inviting (at least formally) people to participate in strategy processes (cf. "the dialogization discourse," Mantere \& Vaara 2008), has become also popular among the popular strategy literature. For instance, Kim and Mauborgne in their bestselling book, Blue Ocean Strategy (2005), emphasize how the execution of blue ocean strategies requires a culture of trust and commitment that motivates people to execute "agreed" strategies. They argue that the successful execution of strategy requires a fair and participatory process that consists of engagement, explanation, and expectation of clarity. The fair process leads to intellectual and emotional recognition, to trust and commitment, and finally to voluntary cooperation in strategy execution. The authors even suggest that the idea of separating strategy formulation from planning is artificial and even harmful for the success of the strategy, and that they should instead be overlapping and coexistent processes. (Ibid., 171-184.) The humanistic macrodiscourse presented here is rather close to this kind of thinking.

\subsubsection{PRAGMATISM: DISCOURSE OF CONCRETENESS AND PRACTICALITY}

As the humanistic macro-discourse enhanced willingness and meaningfulness in strategy work, the pragmatic discourse highlights the significance of concreteness and practicality as a means of understanding and adopting strategy. The pragmatic discourse considers strategy a part of the everyday activities of the organization; in some cases it even says that strategy is action per se. It also stresses the importance of translating strategies into grass root action by making them practical and understandable. 
In the following comments, the pragmatic macro-discourse becomes evident:

"We have most consistently taken the strategies to the grass roots."

“There's no sense of putting some hieroglyphs into strategy that no one understands. [...] That actually means nothing. [...] I've tried to say those phrasings in a way that everyone would understand what it says."

"We have to try to make those strategy guidelines as such that they would catch the people. That they would be easily adopted and [...] concrete."

"[...] keeping the manual and objective clear in mind and doing things, instead of keeping the strategy in the drawer."

"Strategy implementation means that it [strategy] will be taken to the users relatively clear. That what this means just for me?"

"Someone has said that strategy that cannot be changed is a bad strategy. I.e. the ability of the strategy to transform [...] world changes, situations change."

The pragmatic macro-discourse views strategy as some sort of "guidance" that steers the everyday actions of the organization. It says that this guidance should be considered and reflected when making decisions at every level of the organization, all the time. While the macro-humanistic discourse emphasized the meaningfulness of the strategy for the individual, the pragmatic macro-discourse highlights its concreteness and practical value, applicability. The pragmatic discourse also outlines the language of strategy. It says that strategies should be made "clear" so that their meaning for practice is understood. The discourse is against the high-flown and abstract strategy language, regarding it as "hieroglyphs." When strategies are concrete and clear, they are understood and adopted, it concludes.

Like the humanistic macro-discourse, the pragmatic discourse does not make a strong distinction between different actors in strategy. It actually does not even discuss the role of different organizational players a lot. It states that managers are in responsible for concretizing strategy, but says little of their role otherwise. However, the discourse still maintains the top-down approach to strategy by saying that strategies are "taken to the grass roots," implying that strategies are made at the top and then taken downwards. 
In their paper, Mantere and Vaara (2008) discussed a "concretization discourse," which is rather close to the pragmatic macro-discourse. They concluded that the concretization discourse seeks to establish clear processes and practices in strategizing and it views strategy as an inherent, almost mundane part of organizational decisionmaking. This kind of a cry for the practicality and applicability in strategy work is very popular and recurrent, for instance, in popular business books and business press nowadays, where the issue of strategy implementation has been given a lot of interest and attention. The common saying goes that it is not the planning of the strategy, but the implementation that is the most difficult and challenging part of strategy-work. The pragmatic macro-discourse discussed here is a manifestation of that kind of thinking.

\subsubsection{SPIRITUALITY: DISCOURSE OF FAITH AND BELIEVING}

The spiritual macro-discourse does not discuss religion or religious issues as such, but more likely draws on the spiritual rhetoric by comparing strategy to a spiritual experience and practice. The spiritual discourse brings up faith and the experience of it both as preconditions and antecedents of strategy. It regards strategy as something that is almost beyond the material world, connecting it to a metaphysical reality greater than oneself. According to it, strategy is thus a practice that connects oneself with the higher level purposes of an organization and gives people a sense of belonging.

The following quotes are examples of the spiritual macro-discourse:

"Well, it's our intent of where we are heading at, including the vision that is our illusion. [...] Values, for instance, those have remained the same for 20 years. It includes sort of permanent elements."

"Strategy is the means to reach our vision."

"[Strategy includes] assumptions and actions or broadly speaking means that the vision is reached."

"The number of true believers [of strategy] has to be increased."

"Well, from my opinion it requires that you have faith in strategy, and then everything else comes with it" 
The spiritual macro-discourse constructs strategy as a matter of "faith." Faith in strategy enables people to serve something purposeful and greater than their personnel aspirations. Strategy is manifested through "vision" and "mission" statements, both concepts adopted originally from the spiritual vocabulary. Strategy is a practice that gives people mission and vision, a purpose and direction, and connects them with the higher level purposes of the organization. Strategy is a "journey" into the vision for the people. The spiritual macro-discourse also brings up the sense of belonging. According to it, faith in strategy gets people to feel that they belong to the organization and realize its purpose for their own part. While committed to the "values" of the organization, they feel a sense of purpose and significance. Hence, the spiritual discourse emphasizes the symbolic nature of strategy. Strategy is a sacred mission or vision that requires faith in order to live according to it.

The spiritual discourse positions managers as "messianic" leaders, prophets or priests, who have "wisdom" to lead their people to a better future, a prophetic promised land. The role of managers is to believe in strategy sincerely, in order to be able to make their own subordinates believers and disciples of the strategy too. Their obligation is to share and spread the gospel of strategy further. Again, the employees are considered as "followers" closely following the guidance of strategy. Organizational members favorably disposed towards strategy are called "true believers of strategy." Having become believers of strategy, the subordinates become spokesmen of the strategy themselves.

The spiritual discourse is close to what Mantere and Vaara (2008) call a "mystification discourse." When strategies and strategy processes are mystified, neither the content of the strategy nor the role of the top managers is normally not to be criticized or questioned in organizations. Hence, the discourse maintains the hegemony and legitimacy of the management. (Ibid.) The spiritual macro-discourse is also related to a phenomenon called "workplace spirituality." Ashforth and Pratt (2003, 93-94) suggest that this phenomenon has three major dimensions. Firstly, it includes the transcendence of the self, meaning a connection to something larger than oneself. Secondly, it means holism and harmony that relate to authenticity, balance, and perspective of the individual. And thirdly, spirituality means personal growth of the individual calling for the self-development and realizations of one's dreams and aspirations. It has been 
noted (Pfeffer 2003) that spirituality is manifested in different ways in workplaces. In general, people are willing to realize their full potential in workplaces seeking the ways of self-actualization (cf. Mantere \& Vaara ibid.). They also search for social meaning and value for their work and want to be able to feel part of the larger community (Pfeffer ibid.). Many popular business writers (cf. Hamel 2007) have emphasized how this kind of a phenomenon should be capitalized in successful management thinking and practice.

Again, de Certeau (1988, 180-181) discusses how believing, referring to a religious belief, has been exhausted and been transported into different areas of life, such as business. Business has captured the rhetoric peculiar to religion, but the people using that kind of religious discourse no longer believe in religion as such. As a consequence, companies produce credos concerning their values that are inspiring and that motivate their people, and advertising is more and more evangelical by nature. (Ibid.) The spiritual macro-discourse discussed here is a one example of that kind of consumption.

Here, I have discussed the five macro-discourses of strategy, military, mechanism, humanism, pragmatism, and spirituality, in more detail. These discourses are summarized in Table 8. In the following, I will discuss the other two elements of the strategy consumption process, (re)production and usage. 
TABLE 8 SUMMARY OF THE MACRO-DISCOURSES

\section{MACRO-DISCOURSE DESCRIPTION}

MILITARISM (MIL) Strategy is a war plan or projection that guides the actions of organizational members. Strategy aims at winning battles or killing enemies on the battlefield. The organization is in a constant battle against its environment and competitors.

Managers are commanders of their troops, and strategy is executed through their commands and orders. The employees, considered as troops, are responsible for executing these orders obediently.

$\operatorname{MECHANISM}(M E C)$ The organization is a machine that executes strategy through mechanisms and processes. Strategy is a plan that is manifested through targets and objectives that are measured and reviewed with different technologies and practices.

Managers design and set strategy procedures. Through these mechanisms, strategy cascades throughout the organization leaving little room for improvisation or application.

HUMANISM (HUM) Strategies are shared contracts in organizations. Organizations consist of people who are competent actors at every level of the organization.

Participation and dialogue are central requirements of strategy, and the whole personnel should be able to participate in strategy work. Strategy should belong to everyone in the organization and make their work meaningful and motivating for them.

PRAGMATISM $\left(P_{R A G)}\right.$ Strategy is an everyday matter in organizations. It should be considered when making decisions at every level of organization.

Strategies should be made concrete and practical by managers. They need to be taken to the grassroots consistently, so that people would understand their meaning for everyday work.

SPIRITUALISM (SPIR) Strategy is a mission and vision driven intent that requires faith in it. It connects people to a higher level of purposes in an organization and gives them a sense of belonging.

Managers are messianic leaders, who provide direction for their subordinates. However, they have to believe in strategy themselves; otherwise they cannot communicate it in a credible way.

\section{2 (RE)PRODUCTION}

(Re)production is a discursive practice that constructs, (re)produces and maintains strategy as a management discipline. ${ }^{18}$ It brings strategy into being by defining the discipline of strategy at the societal level and localizes it to the case organizations. (Re)production describes how the managers see and consider the discipline of strategy but unlike the usage of strategy, (re)production does not discuss the actual use of the

\footnotetext{
${ }^{18}$ A more detailed description on how the (re)production was constructed from the data, was provided in
} Chapter 3.3.3. 
strategy. (Re)production is done by means of the five macro-discourses of strategy discussed previously. As each of these macro-discourses constructs and holds its own views and ideas about strategy and strategy work, the managers may use them skillfully as resources when (re)producing strategy. These macro-discourses exist in a wider social context, which means that they are brought into the case organizations from outside and are imported discourses by nature. They can be recognized from the case organizations as well as from the wider strategy and management discourse.

The (re)production of strategy is a very dominant, obvious and visible part of the strategy consumption in the data. In most cases, (re)production originated as a result to a question like "How do you see strategy?" in the interviews, but it was also the topic that the interviewees returned to at different phases of the interview situations. (Re)production constructs an epic narrative of strategy outlining and discussing not only strategy and strategy work peculiar to each case organization, but also ideals that are present in the wider strategy discourse. (Re)production is a rather normative and idealistic discursive practice by nature. It often consumes strategy as something that it should be, rather than something it actually is at the moment. For most parts, (re)production is also faithful to the rational strategy approach, and managers seem to be very keen on it. This could be read as a sign of dominance, which the rational strategy discourse has over managers.

\subsection{USAGE}

Although (re)production is an essential part of the strategy consumption process, the main interest in this study is put on the second phase of the process, usage, which could be characterized as a "quiet" part of strategy consumption. ${ }^{19}$ Usage is a discursive practice, which describes how the managers use and poach the strategy, (re)produced preciously, with creative ways. The macro-discourses of strategy are also applied as resources in this discursive practice, but with a more clandestine and subtle manner. Usage is rather hidden by nature, since it is scattered over the

\footnotetext{
${ }^{19}$ A more detailed description on how the usage was constructed from the data, was provided in Chapter 3.3.3.
} 
(re)production of strategy. It represents "devious" and "dispersed" talk that does not manifest itself through its own products, but more likely through "ways of using" strategy. (De Certeau 1988, xii-xiii.)

Previously, the nature of consumption was characterized by two examples. Firstly, the Indians used the laws, practices and representations that were imposed on them by the Spanish conquer in ways that did not comply with their original purpose. Secondly, a North African living in Paris lives there in a manner peculiar to his/her native Kabylia and furnishes his/her new neighborhood with the desires and dreams that longed to his/her old home. (Ibid., 31-32.) In both examples, these human subjects were not able to escape or own the structures (sanctions and an urban environment) that were imposed on them, but they could subvert, apply, and use them in ways that they find useful and fitting for themselves. By so doing, they operated between the imposed structures and the use of them creating space to maneuver and improvise within and between those structures. Here, the strategy usage practiced by the managers resembles this kind of consumption in various ways. Like the Indians and the Kabylian, the managers use strategy that is imposed on them in creative and original ways.

Strategy usage can be further divided into three sub categories of talk that each describe different sides and styles of strategy usage. Here, the strategy usage is manifested with three types of tactics, the concept adopted from de Certeau (ibid., xiv), to illustrate different sides of polyphonic strategy use. These three tactics are instrumental, playful, and intimate. When coping with the strategy discourse, managers are like drivers in the streets of Rome or Naples (ibid., 18), who are navigating forward through strategy labyrinths with these three usage tactics.

\subsubsection{INSTRUMENTAL TACTIC}

The instrumental tactic uses strategy as a device, an instrument, which is used as a means in a managerial work. The tactic aims at making strategy habitable by adapting and poaching it for managers' purposes of some kind. The instrumental strategy usage may, at first glance, appear like a literal adoption of strategy discourse, but once you take a closer look into it, you notice that it is often the letter of strategy that is used, not the spirit. To some extent, instrumental strategy use bends the rules of strategy by revising and applying them to drive one's own agenda. 
When using strategy instrumentally, managers catch the rational ethos of strategy and the language of it, but use it for their own purposes and intentions instrumentally with ways that may fall apart from the (re)production of strategy. This is an example of "bricolage," ("an artisan-like inventiveness," cf. Jarzabkowski 2004) an activity that combines and connects bits of strategy discourse to managers' own repertoires. Strategy is obviously an instrument that is being played rhetorically. The instrumental talk is manifest in the expressions that describe strategy as a "way" or "means" to do something, or managers may describe how "strategy means" this and that for them.

For what purposes is strategy used instrumentally, then? In some parts of the instrumental tactic, strategy is used for a manager's personal goals and purposes. Here, the managers may apply strategy for their own purposes, such as building legitimacy for their work (cf. Knight \& Morgan 1991) and solving practical problems. However, in many cases strategy is used for more collective purposes, mainly for the benefit of a manager's unit, in some cases even for the sake of the whole organization. In many cases, instrumental strategy consumption aims at coping (Chia \& Holt 2006) with the strategy. It may not necessarily turn strategy into something totally different, since it does not have the power to do it, but more likely operates within it by plying it and trying to cope with it.

\subsubsection{Playful taCtiC}

The second usage tactic is called playful. While the instrumental tactic adopts strategy and maintains its rational ethos by using it instrumentally, the playful tactic takes strategy more creatively and less seriously. It is also more critical towards strategy than the instrumental tactic. For most parts, the playful tactic embodies a critique and resistance towards strategy, which can be read as a sign of cynicism from the managers. However, playfulness is not an explicit resistance of strategy, but more likely opportunistic, subtle and silent pragmatism, which resists and subverts strategy implicitly and quietly in its own terms (Fleming \& Sewell 2005).

Humor is a central feature of the playful strategy consumption. Ironical and cynical humor is used with a carnivalistic way to subvert and resist the power of the strategy discourse imposed on the managers. Irony provides a way to criticize and challenge the sacred norms of the strategy in a way that might be considered illegitimate, if ex- 
pressed in any other words. Irony represents rhetoric that brings managers apart from strategy and channels criticisms, disagreement, and/or frustration towards it, and it is dissembled in such a way that it is difficult to understand without knowing the context wherein it is used. Playful strategy use could also be read as cynical by nature. Being cynical, it sees through the strategy and its practices, and considers them to be repressive by nature. The playful tactic also uses contradictions and comparisons as rhetoric resources when illustrating the absurdity of strategy in some cases. (Ibid.)

The playful tactic is used to maneuver and create space within the hegemony of strategic management. The playful tactic is also a comedic strategy narrative that constructs strategy as a carnival. In the playful tactic, managers take strategy and consume it in a playful way to amuse and entertain themselves. Strategy is used playfully mostly for pleasure: "the pleasure of providing one's own meanings of social experience and the pleasure of avoiding the social discipline of the power-bloc" (Fiske $1989,47)$. Since the managers are in a position of not getting away with strategy, they are obligated to live with it. In de Certeau's terms (1988, 31-32) they "transfer it into to another register." Playful usage does not produce any material outcomes for the managers, and neither are the managers able to accumulate what they win, but what they do keep is their status and subjectivity (Fiske ibid., 36). Managers may also disindentify themselves from strategy, criticize it, and amuse themselves with the ridiculous aspects of it, but still perform it in their work. By doing this, they both disidentify and (re)produce strategy at the same time. (Fleming \& Spicer 2003.)

\subsubsection{INTIMATE TACTIC}

The third tactic is called intimate. In this case intimacy means personal experience, managers' personal relationship and attachment to strategy. Here, strategy is neither an instrument to do something, nor something to play or amuse oneself with, but an arena that provides managers a way and means to construct their existence, subjectivity, and identity in relation to it. Where as in the playful tactic, the managers resisted strategy's colonization of their subjectivity playfully, here they instead use the strategy discourse to construct and shape their subjectivity and identity as managers. They use strategy "narcissistically pleasing oneself, instead of others" to summon up their emotional desires and pleasures (Featherstone 2007, 27). 
The intimate rhetoric also describes managers' own personal feelings, such as fears and insecurity, towards strategy. The intimate talk has a shade of shyness or sensitivity in it, while it reveals something private and literally intimate about manager's relation to strategy, something that is not told publicly. By using strategy with this way, managers reflect and construct their subjectivity in terms of strategy work. Here, in the case of the intimate strategy usage, de Certeau's remarks about the "clandestine" nature of consumption become materialized most obviously.

This chapter has provided a description and overview of the elements of the strategy consumption process. The following three chapters present the case-specific results of this study. I will answer the primary research question "How managers consume strategy?" by describing how the strategy consumption process, described previously, is manifested in each case organization. Also, the case-specific "contexts of use," as de Certeau $(1988,32)$ calls them, are outlined in order to illustrate and elucidate the contextual factors of strategy consumption. Particularly, I will try to narrate how strategy is practiced in each case organization and what the managers make out of strategy by analyzing the strategy (re)production and usage in them. I will also study, how different discursive resources, imported strategy discourses, are utilized and used in strategy consumption in each case organization. 


\section{INDUSTRIAL ENTERPRISE}

Industrial Enterprise (henceforth Industrial), my first case organization, is a traditional industrial corporation with a rather extensive history, dating back to the beginning of the $20^{\text {th }}$ century. Industrial manufactures industrial products for different customer segments and it is divided into five business units, each taking care of their market operations around the globe. The personnel of the business units consist mainly of sales and marketing people. The manufacturing operations of Industrial take place mainly at a number of production sites situated in Europe. Industrial's top management and main support functions (finance, personnel, communication, IT, etc.) are located in its corporate center situated in Finland. Industrial's business is regarded as “heterogenic," because of many lines of business in different countries and cultures.

Although Industrial operates like a self-governing company, it is fully owned by its parent company. However, it seems that its relation to the parent company is rather complex. The parent company does not regard Industrial as its core business and has tried to sell Industrial during the past few years, although it has not yet succeeded. It is obvious that in this situation the parent company does not want to invest any extra money or resources in Industrial. This stalemate frustrates Industrial's managers. Obviously, they are not satisfied with their role as cash flow producers, but would like to develop and invest money in their businesses. In some way, it seems that Industrial has been - more or less - abandoned by the parent company. Some managers even say that the current situation is preventing Industrial from realizing its strategy in the preferred way, and that the parent company does not know what to do with Industrial. Many of them seem to be waiting (and hoping) that something will sooner or later happen in the ownership of Industrial, but no one seems to know what that would be. 
Some even say that they do not see an "inspiring future" for the Industrial in the current ownership.

Industrial has traditionally been first and foremost a product-oriented company. Hence, the site managers were previously dominant players in its strategy process. One site manager recalls how the site managers used to drive to the "big meetings" held at the head office in their "black cars," and explained what they had decided to produce during the next year. Back then, the production sites were "small monarchies" within Industrial. However, during the last few years the management of Industrial has advocated a more customer-oriented strategy that is based on knowledge and solutions. According to this new strategy, it wants to be a trusted and qualified partner to its customers and provide tailor-made solutions to them, instead of being a bulk manufacturer. It aims to move closer to the end user in the supply chain. This is a classic example of moving from a cost leadership strategy to a differentiation strategy. It is a typical strategic change recently sought by many industrial companies in Western Europe. At Industrial, this change creates tension between the intended strategy and the current state of Industrial.

Industrial's new strategy is explained and justified by the changes that have taken place in the company's business environment. The prices of raw materials have increased dramatically, thereby causing pressures on product prices. And at the same time competitors from Eastern Europe have cut market prices heavily, causing heavy pressure on Industrial's pricing. Managers repeat over and over again that Industrial operates in a very turbulent, challenging and "competitive" environment, and that the entire industry will most likely face rearrangement and consolidation in the future.

Due to the changes in Industrial's strategy, the business unit managers have replaced site managers as the dominant players in the strategy process. The site managers are not, for example, invited to the annual strategy meeting anymore, which is a crucial symbolic milestone in Industrial's strategy process. The meeting is an away-day, held in the summer at a countryside mansion. The meeting lasts for two days and also includes a leisure program with good food and beverages, making it not only a strategy meeting, but also an institutionalized socializing event for the top managers of the company. The fact that the site managers are no longer invited to these meetings is 
interpreted as a symbolic gesture by them: it means that they are no longer important and that their insight is no longer needed in Industrial's strategy process.

Nowadays it is the business unit heads that bring the strategy to the site ones a year at site-specific target setting events. In these sessions, the business-unit managers communicate the strategic targets for the site managers, who primarily listen to what the business expects from them. This phase of the strategy process is called "strategy sharing," although at least the site managers think that it is more likely one-way implementation.

Although Industrial tries to emphasize customer focus and customized services in its new strategy, especially the sites seem to operate with mass production logic. Their culture is "ton-oriented," as one interviewee describes it, and they aim for "productive efficiency." In contrast, the business units have a different standpoint. While responsible for market operations, they have adopted a new customer-oriented strategy, in which they can see their own handwriting more easily. They sell "customized concepts" to customers. This difference causes some conflicts between these two groups from time to time.

Industrial has a documented strategy process chart that basically constitutes the central artifact of strategizing in the company. It is the way the "machine works," as some managers describe it. Strategy work at Industrial follows certain annual procedures like planning, target-setting and review practices.

\subsection{STRATEGY (RE)PRODUCTION}

As discussed earlier, strategy (re)production is a discursive practice that defines, explicates, and acknowledges the premises of strategy for the further usage. In this chapter I will show how strategy is (re)produced by the managers of Industrial. Strategy (re)production at Industrial follows three paths. The first (re)produces the nature and conditions of strategy at Industrial. Strategy is constructed as a means to reach the vision, referring to the spiritual macro-discourse. The second path discusses how strategy is done in the company, especially how its strategy process functions. According to it, Industrial's organization works like a machine to realize the intended strategy, 
which refers to the mechanistic macro-discourse. The third path invites the personnel of Industrial to the strategy work. Strategy is (re)produced as an activity that requires participation and commitment, and invites the humanistic macro-discourse along. These three (re)production tactics set the scene for further strategy usage at Industrial.

\subsubsection{WAY TO REACH THE VISION}

The following quotes from the managers of Industrial illustrate how strategy is (re)produced firstly by them.

"It [strategy] is the way we reach the vision [...] like the condition of life or a manual for success."

"Strategy is a plan, a concrete plan how to reach the vision."

"We have like vision and mission [...] strategy is a means, then, certain actions and projects through which the desired state is aimed at."

"It [strategy] is such a big collective desired state and outlook, a collective outlook of how the company can succeed."

In this rhetoric, the spiritual macro-discourse is used as a resource to (re)produce strategy. Strategy is portrayed as the "way," "plan" or "means" to reach the "vision." It is like a journey to salvation for the strategy believers. A journey that requires consistency and strength, but once you get there, it rewards you extensively. This kind of journey metaphor is commonly used in strategy discourse and in management rhetoric in general (Inns 1996). It is interesting how the terms "vision" and "mission," both of which derive from the spiritual macro-discourse, are (re)produced by the managers of Industrial so frequently and consistently. This may indicate that the spiritual macro-discourse is deeply rooted at Industrial, although the consumers, here managers, probably do not recognize the religious underpinnings.

Strategy is also portrayed as the "precondition of life," "the manual for success," or "a collective outlook of the desired state:" this also suggests that the nature of strategy is almost metaphysical. Nevertheless, it is at least something that can be seen in the future as the following comment suggests: 
"Well, if we think about strategy creation, it is very important that we are able to analyze the environment and customer expectations. It's like, we are able to see far ahead."

It appears here that strategy is (re)produced as something that requires seeing " $\mathrm{far}$ ahead," as the previous manager says. Sight is in fact strongly highlighted in the strategy (re)production. Strategy can also be a war plan, as the following quote reveals:

"[Strategy is] the way we try to win the war against competitors and against the environment. This is the starting point."

The previous quote is a reference to the militaristic macro-discourse. Strategy aims at "winning the war." What is striking here is that strategy is considered as a war not only against "competitors" but also against the "environment." According to this interpretation, it seems that Industrial is at war on many fronts. This may reflect both Industrial's tough competitive situation in the markets and the unclear ownership situation that is puzzling many managers.

\subsubsection{PROCESS ORIENTED}

The second path of the strategy (re)production treats strategy as something that is accomplished in the organization through the process. A manager describes the strategy work at Industrial as follows:

"Yeah, and let's say that this big machine then spins like the clockwork described [in the annual strategy cycle]."

Again, another manager illustrates how the Industrial strategy is further divided into business plans:

"Well, to put it shortly, we have some intention of what we want to accomplish, a vision state, and then we have a predefined mode of operation, and then we have a disciplined practical implementation. The process is very logical, as it can be in an engineer-based firm. The strategy is formulated at the top management level of a firm and then it is cascaded through these different business plans into practical action." 
Here, another manager illustrates how Industrial level strategy is taken further in the organization:

"Well, how is it implemented? Well, it sort of happens through this process [...] The chosen strategy [...] the BU business plans are made of it [...] and the market based and country based business plans are made of it, and then, based on those business plans, the team and personnel discussions are held [...] we will hopefully get those targets in synchrony so that the machine works in the same rhythm."

All three descriptions of Industrial's strategy work reveal the clearly mechanistic underpinning of the (re)production. The organization is a "machine" that should work "in the same rhythm," in "synchrony," in order to realize the desired strategy. It is this machine that spins like "clockwork" or according to a specified procedure. Strategy relies on the "logical process," natural for the "engineer based" firm, that "cascades" strategy into "practical action," presumably downward in the organization. Strategy is created by "the top management" of the firm.

This kind of strategy (re)production leaves little, if any, room for improvisation and creativity. Strategy requires literally "disciplined" implementation. Strategy cascades in the organization, starting from the corporate level and ending on the personal level. Strategy should clearly guide the activities and goals of individuals and teams. What is interesting here is that those managers do not seem to place themselves in this machine. Managers are engaged in strategic planning processes; they analyze the business environment, produce strategic plans, and then try to implement them effectively throughout the organization, which is considered to be a machine. But they do not reveal that are they part of the machine themselves.

\subsubsection{EVERYONE'S CONCERN}

In the third path of the strategy (re)production, the managers of Industrial explain how their strategy process involves people, referring to the humanistic macro-discourse. However, the mechanistic and spiritual macro-discourses are also brought into play, which makes the (re)production an interesting mixture of different macro-discourses. 
Here a manager describes Industrial's strategy process:

"[Strategy process is] an on-going process and it should touch as many Industrial people as possible, i.e. the whole personnel."

Industrial's strategy process chart includes a phase called "strategy sharing," referring to the phase where Industrial level strategy is further communicated to the business units and production sites. In the following, a manager explains what this means:

"[...] share strategy, this is how we have to get the people to understand the environment and the validity of the vision, and then how the organization commits to the strategy."

Further, another manager explains the company's strategy process:

"This is a process that concerns the whole personnel. It will be taken to the last person, since everyone can sort of implement strategy. It is only frame setting, so that people would begin to think the right way. [...] You can find things in the strategy that you can easily identify with. It also kind of guarantees better work quality for them. It sort of explains why these things are done. [...] It cascades right [down] there to the employee level, right there where the strategy is accomplished in their work."

The previous quotes reveal how the humanistic discourse is (re)produced at Industrial. Humanism is almost a normative rule for the managers. It is said that the strategy process "should touch the whole personnel" of Industrial and the process "is taken to the last person" in the company. As a result, strategy guarantees "better work quality" at Industrial and appear almost like the source of emancipation or salvation. Strategy gives people "an idea" of why certain things are done at Industrial. Here, strategy provides people with a sense of meaningfulness and purpose, which could be read as a reference to the spiritual macro-discourse.

However, as can be seen, the mechanism is also used here as a resource. Sharing strategy means "getting people to understand the environment and the validity of the vision" almost as if they were machines that should be tuned into the right frequency. This is called "frame setting" and aims to get "people to think the right way." Based on this clause, there is obviously the right way to think about strategy, according to 
the manager. But who gets to decide what the right way to think about strategy is? Is it the frame-setter? So it appears, since the strategy "cascades" down to "the employee level" where the "practical" work is done. Compared with the humanistic and spiritual macro-discourses present in the very same quotes, this kind of mechanism sounds almost violent.

The (re)production of strategy described here sets the scene for further strategy usage at Industrial by bringing strategy into being at the societal level and by contextualizing it into Industrial. As has been mentioned, this is the most outward and obvious part of strategy consumption. Next, I will show how this (re)produced strategy is used and applied by the managers of Industrial in a more clandestine and tacit manner. I begin with the instrumental usage tactic.

\subsection{USAGE: INSTRUMENTAL TACTIC}

At Industrial, the instrumental strategy usage seems to include four types of talk. Firstly, managers use strategy as a sort of sensemaking tool to analyze and understand their business environment. Secondly, they use strategy to formulate and set objectives and targets for themselves and their subordinates. Thirdly, they use Insurance's strategy as a loose framework on which to build their own sub-strategies and goals. The looseness leaves them some room to maneuver and act more independently in their work. And finally, managers create sub-strategies to ensure and secure that their unit is in line with Insurance's strategy to appear important and legitimized for others.

\subsection{1 "UNDERSTANDING THE BUSINESS"}

The first element of the strategy usage at Industrial is no surprise by any means, since it probably reflects the most typical managerial activity related to the strategizing. Here, managers use strategy as an instrument to analyze and evaluate their and their units' businesses. In the following, two managers describe this kind of strategy usage in more detail: 
"We have a sort of pretty wide strategy team, where we discuss strategic issues. [...] With that crowd, we think about changes in the business environment and how they affect our strategy."

"Understanding customer needs and understanding the business environment. Understanding our own strengths and also understanding our own development areas, that you're not allowed to be weak. [...] Well, [...] we started a sort of strategy process last year, where we defined [...] what our strengths and weaknesses are, and tried to understand where our customers are heading, and the business environment."

What does analyzing the "business environment" mean for the managers? The obvious purpose seems to be to "understand" the business environment and the conditions related to it. It seems that this kind of strategy use allows managers to gain an understanding of their external conditions, such as customers and "changes," and also of their internal conditions, such as "strengths" and "weaknesses." It appears that the managers have applied the SWOT analysis in their strategy sessions.

This first element of the instrumental strategy usage draws loosely on the humanistic and mechanistic macro-discourses. Firstly, strategy-making is portrayed as an activity that is done in a rather wide circle of managers, who "discuss strategic issues." This comment is influenced by the humanistic ideals of open participation, communication and dialogue. The second quote relies on the mechanistic macro-discourse by describing how strategy-making is driven by the "strategy process," which has been started some time ago. It almost sounds like you were not capable of thinking strategically without a sufficient process that ensures the quality of strategies.

Here, strategy clearly appears as an analytical sensemaking tool for the manager. By launching the strategy process, the manager has been able to gather his/her people to think about the nature and conditions of their business unit together. Strategy-making may also provide them with space and time to stop and ponder some basic questions concerning their unit and its work in a legitimized setting - something they would be unable to do while running the everyday business. As a result of the process, managers "define" and construct their strengths and weaknesses, which means that the strategy-making gives them some outcomes that can be returned to later. 
The manager also mentions how the strategic analysis is done because "you are not allowed to be weak." Could it be that the managers are engaged heavily in creating their own sub-strategies to avoid appearing vulnerable or weak? Does the strategy and strategy process give them a sense of being in control of things? Does the strategy make them look strong and appear to be rational managers? It seems that the managers use strategy as the instrument like this, not only to ensure that they are aware of what goes on in their business environment, but also to legitimize and ensure that they are tough business managers capable of managing their units within Industrial. This is an example of strategy usage that follows the spirit of the rational strategy approach consistently and obediently.

\subsection{2 "THE GOALS ARE DERIVED FROM THE STRATEGY"}

The second feature of instrumental strategy usage is a tactic that applies strategy for setting targets and objectives. Here, the targets set are derived from Industrial's strategy and then cascaded further in the organization. In the following, a manager describes how these strategic targets are set in his/her unit:

"Then we have this target setting day, where we get the general Industrial lines [...] The output is the Balanced Score Card that we put on the intranet. [...] Then we [...] make the objective matrixes [...] Teams will do an exercise, that what does it mean for them, and set their own targets [...] The targets are being taken to the team level [...] If this process works, they [targets and goals] are derived right from Industrial's strategy. [...] Here, we have some concrete suggestions [...] that you have to drive the fork lift faster, and so forth."

"In practice, $[\ldots]$ everyone's personal goals are derived right from the strategy."

While the unit has received the Industrial level strategic “lines," those guidelines are translated and divided into team level targets for all employees in the unit. The manager acts like an operator who runs this process, which is an example of pure mechanistic talk. Practices like the Balanced Score Card and objective matrixes are used as tools in this target setting process. The manager ensures that the "goals are derived right from the strategy," which hints that strategy is taken seriously here. Then, the 
targets are "taken" downward in the organizations so that even "the fork lift driver" on the plant floor follows some sort of strategic guidance.

Here, strategy appears as an apparatus that both defines and cascades the "targets" and objectives at Industrial. The manager uses Industrial's strategy as the bases for targets and goals at his/her plant. While instrumental usage treated strategy as a sort of collective sensemaking tool, here the strategy disciplines and controls the activities of individuals. Although teams do "an exercise" where they reflect what the strategy "means for them" and "set their own targets," the targets are derived straight from the strategy.

\subsection{3 "IT'S A GOOD GUIDELINE, BASICALLY"}

In the third feature of the instrumental strategy usage, managers take more freedom to maneuver and manipulate the strategy. Here, they use Industrial's strategy as a loose framework on which to build their own sub-strategies and goals. They reinterpret and shape it to make it habitable for themselves and their own units. In the following, a manager describes how he/she takes Industrial's strategy and what he/she makes out of it in his/her unit:

"Well, particularly the investment side. That is quite essential for us. Otherwise, [...] you can work quite independently, as long as you make a profit. They don't pay an awful lot of attention to how you make the profit. [...] Industrial's strategy tells mostly the businesses we want to be in. [...] Industrial's strategy limits the scope of the business units, but as such, a business unit can create its own strategy rather freely on those conditions."

The manager regards Industrial's strategy as a rather loose framework. It tells him/her "the businesses" that the company "wants to be in" and limits the "scope of business," but otherwise lets him/her manage the unit "quite independently." The only thing that seems to be essential to him/her is "the investment side" of strategy, not the vision or mission, nor the strategic intent. As a result, he/she can create his/her "own strategy rather freely." What justifies a manager's behavior here is the ability to "make a profit." As the manager puts it, "they don't pay an awful lot of attention to how you make the profit." Money matters here. 
In the following, the same manager explains how he/she takes the intent of Industrial's strategy:

"Well, the 'partnership' thinking, this is the leading thought [in Industrial's strategy]. On our behalf, I'll try to live with the message, but I can't go on and tell it to our customers, because they won't understand [it]. [...] We are so different than the others [...] Basically, we can subscribe to that and try to develop it. But at the moment, we have little 'partnership', and 'knowledge' we don't have at all, and if you don't have them, you can't provide 'solutions' either. But it [strategy] is a good guideline [...] It's only a matter of will. [...] It's the direction."

"Partnership thinking," which is the cornerstone of Industrial's newly described customer focused strategy, is regarded and used as an unsuitable choice for the business unit in question. The business unit manager is trying to cope with the strategy, because he/she cannot tell it to his/her "customers," who would not understand it. The manager's unit differs from the others. Since they have "little partnership" and they lack "knowledge" totally, neither they can "provide solutions" to their customers. The manager seems to acknowledge that strategy requires some sort of faith when it is regarded as "a matter of will" and a "direction," which could be read as references to the spiritual macro-discourse.

Here Industrial's strategy is used instrumentally as a basic guideline, as a direction, that has little impact on the actual activities of the business unit. In de Certeau's terms, Industrial's strategy is made habitable here. The manager is trying to cope with the strategy, which he/she doesn't find useful for his/her unit, but since he/she cannot fully ignore it, he/she "tunes" it. He/she makes it function in another register, as de Certeau put it, so that he/she and his/her unit can live with it. By doing this, he/she can work quite independently, as long as he/she makes a profit.

\subsection{4 "WE HAVE CREATED OUR OWN SUB-STRATEGY"}

At Industrial, the managers seem to have a rather strong need and interest to formulate their own sub-strategies, which are based on Industrial's corporate strategy. In the following, the managers of Industrial discuss this phenomenon and reveal why they en- 
gage in such activity. Here, a communications manager describes how his/her team has created a communication strategy based on the Industrial's business strategy:

"Well, we of course have [...] a communication strategy that is, of course, totally based on the corporate strategy. [...] Our task is to advance those key issues and key targets that are derived from the corporate strategy [...] We create a sort of corporate image that is in line with our mission and vision [...] But, then again, internally [...] we have a very important task [to ensure] that people [would] understand what our strategy is all about and why it is like that [...] Our task is to [translate] the message that they [would] understand what we are talking about."

The communication strategy is "based totally on the corporate strategy" of Industrial. What does this strategy include? It seems to be the manifestation of the tasks of the communication department. Their task is to "create a corporate brand" and to ensure "that people understand" what Industrial's strategy is about. Here strategy appears to be a framework that legitimizes the work of the department and ensures that its work is in line with Industrial's strategy. Strategy describes and defines what the department does and makes its work meaningful and tangible for others. By creating a sub-strategy, it is assured that the department performs an "important" strategic role at Industrial.

Here, a site manager describes his/her efforts to create a similar kind of a strategy:

"I also have a task from my supervisor to create a production site strategy. The hell with it! I can do it. I will do a one hour slide show [presentation] about it, but, you know, there's no channel to integrate it into the rest of Industrial. I think you needed some frankness. [...] A vision of what our plant will be after two years, that's what we are after. That's what I would like to finally find out, since I'm responsible for the unit. It'd be really nice to know in which direction this is being taken."

The site manager has been given a "task" to create a strategy for his/her production site, but unfortunately he/she finds no way to "integrate it into the rest of Industrial." The production plant strategy would define "what the plant will be after two years" and where the manager should take it. Here, the site manager is missing the security that the communication manager enjoys; he/she does not have a way to link his/her 
work into the whole. Right now, he/she lacks a strategy that would ensure that his/her work is meaningful and important for the company. He/she is missing a connection to Industrial's strategy and thus regards his/her work un-important and unattached by its nature. Here, the mechanistic macro-discourse is visible through expressions such as "channel," "integration" and "input." The previous comment could also be interpreted as a slight reference to the spiritual macro-discourse, since it emphasizes the security that results from belonging to the community and feeling connectedness to something greater than oneself.

It is obvious that the managers of Industrial create sub-strategies to secure and ensure that their and their unit's work is related to the whole and appears important and meaningful. They want to appear strategic and thus important for the rest of the organization. They use strategy to legitimize their and their units' activities and to build a connection between their work and the goals of the organization. Strategy is used almost like a glue to connect and link one's own activity into the organization.

\subsection{USAGE: Playful TACTIC}

The playful usage tactic questions the status of Industrial headquarters as the central strategist and jokes about the ability of the top management to act as a visionary leader. The playfulness also brings out the cultural differences between different parts of Industrial preventing it from operating as one "machine" in "the same rhythm" as the (re)production insisted.

\subsection{1 "THE IVORY TOWER AND THE FORKLIFT DRIVER"}

As the (re)production of strategy described previously, the strategy process has an important role in Industrial's strategy work and it intends to take the strategy mechanically down to the last employee of the company. In the following, a manager uses strategy playfully by joking about the role of Industrial's headquarters as an operator of the strategy process:

"These folks can twist those [strategy] processes by themselves and think about those methods and think how the strategy will be achieved and how it will be 
taken to the folks. But what we can't always see by ourselves, of course, is that why do I bang my head on the tree? That what is that tree that I'm banging my head on? It's difficult, when you are, like we say at the production site, here in the ivory tower [headquarters of Industrial]. It's difficult to understand why the damn forklift driver doesn't understand what we have decided in the management board."

This satiric description jokes about the top management of Industrial. The quote creates tension between the two extreme groups of Industrial. The top management, positioned at the "ivory tower" above the rest of the organization, does not seem to have an idea of what is going on elsewhere in the organization. It seems that they can see far from their tower, but fail to see near. Here, ivory tower represents wealth, power and status, something that the personnel, "these folks," can only dream about. It seems that the top management has somehow isolated itself from the rest of the organization. The ordinary people of Industrial, like "the damn forklift driver" working on a production site, do not understand the strategies created by the management.

The manager also jokes that the top management is "banging" its head on a "tree" without knowing what that tree actually is. It is clearly trying to get the "folks" to adopt its strategy without being able to do it. The reason, "a tree," remains somewhat unclear here. It almost appears that the manager is advising the top management to step down from their tower.

What is the purpose of this kind of consumption? The manager telling this satiric description obviously knows the problematic situation at Industrial. Nevertheless, he/she is not a forklift driver him/herself, neither does he/she belong to the ivory tower; but he/she is somewhere in between these two extremes. It seems like he/she has his/her own way to do strategy. He/she is also somehow above this situation, being able to make fun of it. He/she can watch both the top management and the forklift driver, the one banging its head on the tree and the other driving with his/her forklift in his/her own direction. The manager might be cynical about the strategy and dis-indentify him/herself with it.

This is also an example of how the mechanistic macro-discourse is used playfully. The manager is sure that "these folks" at the production sites and elsewhere can take 
care; they can "twist" the processes by themselves. They do not need the ivory tower to do that.

\subsection{2 "OCCULTISM AT THE UPPER FLOOR"}

Previously, Industrial's strategy work was (re)produced as a vision- and missiondriven process, with the spiritual macro-discourse as a resource. In the following, a manager uses strategy playfully when describing the efforts taken to communicate these visions thoroughly in the organization:

“Well, now it has been agreed [...] that this [strategy] won't be occultism, management's coffee moments where soft things are discussed, [...] strategic feet off the ground things. This [strategy] will be communicated intensively to the whole company."

This statement illustrates the future intentions of Industrial with regard to strategy communication. Strategy will be communicated "intensively to the whole company." But why do this? This is where the playful usage steps in. Without communication, strategy can appear as an "occultism," which refers to the spiritual discourse. By comparing strategy work with occultism, the manager hints that sometimes Industrial's strategy work could have been regarded as a clandestine discipline or activity, kept secret from the public. It may also hint that when kept secret, the strategy work may seem paranormal, supernatural or magical to others not involved in it. This kind of an activity is also portrayed as "management's coffee moments" where they discuss "soft, strategic feet off the ground things."

This kind of rhetoric does not paint a particularly favorable picture of Industrial's top management. On the contrary, it actually hints that without communicating the strategy, the top managers appear as occultist figures discussing high-flown "strategic" things that do not have much to contribute to the everyday work of the organization. This is playful rhetoric, indeed. The pragmatic discourse is also present here. The comment can be read as a cry to concretize and make sense of the strategy. The comment can also be interpreted as a struggle between the spiritual and pragmatic macrodiscourses. 
The following comment from a manager continues the thought:

"Previously [...] there was a feeling, let's say like before the current management, that we drifted. The upper floor dreamed up something, and the ground floor did something else, something like it."

This comment plays with a common stereotype associated with strategy work. As the instrumental tactic indicated, at Industrial, too, strategy is created mostly by the top management, referred to here as "the upper floor," and implemented by the personnel, "the ground floor." In this quote, this whole thing is made fun of. Top management has previously "dreamed up" something, and the personnel have done "something else." This is a satiric account of the situation, where two floors definitely do not "play in the same rhythm" as was demanded previously. More likely, this constructs a humoristic picture of Industrial's top management dreaming strategy dreams on the "upper floor" without knowing what is being done downstairs. The comment can also be read as a wish to concretize and clarify strategy for preventing further "drifting." This is a reference to the pragmatic macro-discourse.

Here, managers use strategy not only to entertain and amuse themselves, which is obviously one purpose of this kind of talk, but also to criticize the current (or previous) way of the strategy making at Industrial. Also, while giving them some pleasure, it may also distance them from that kind of strategy work and construct them as capable and knowledgeable with regard to these issues.

\subsection{3 "TRIMMED PRODUCTION PLANTS AND SERVICE PROVIDERS"}

The (re)production of strategy highlighted how Industrial's strategy process should ensure that the organization works as a whole. In the following, a manager plays with the differences between the business units and productions sites in a manner that questions the idea of unity:

"Then, here at the production sites, well, they are trimmed production plants all the way. [...] Goddammit, they push as much stuff from their pipes as they can. And their goal is productive efficiency. And then, all of a sudden, these [business units] are trying to sell services and focused concepts according to the strategy. Well, this creates a contradiction." 
According to the manager, the production sites of Industrial are "trimmed production plants" that are producing goods with mass production logic, trying to be as effective as they can. "They push as much stuff from their pipes as they can," says the manager. On the other hand, the business units, as the pioneers of the newly created strategy, pursue customized solutions and concepts. Here, these two contradictory logics collide, creating the "contradiction." "Goddammit," groans the manager, while sharing his/her concerns about this stalemate.

The previous comment is an example of the playful strategy usage that is targeted against the ideals of strategy (re)production. Here, a dichotomy is constructed between the business units and productions sites as a sign of the controversies and difficulties that Industrial is facing in the strategy work. Here, strategy appears as a source of amusement for the manager. It is almost like he is watching this entertaining play and laughing up his/her sleeve. This is pleasure felt in front of the almost impossible challenge. What else can you do but laugh? This kind of talk can be read as a reference to the pragmatic macro-discourse, since it plays clearly with the problem of turning the intended strategy into concrete action.

\subsection{USAGE: INTIMATE TACTIC}

In the following, I will show how the intimate usage tactic is used for three different purposes at Industrial. Firstly, managers use strategy to glorify themselves as strategic leaders who are capable and legitimized to lead the company. Secondly, managers use strategy to highlight the lack of support and loneliness felt in the company's strategy process, which constructs them as disrespected and misunderstood. And thirdly, strategy is used to illustrate managers' dis-identification with the strategy that portrays them as independent and unconnected of it. The intimate tactic discusses how the managers feel personally about Industrial's strategy and how it either emancipates or neglects them. 


\subsection{1 "BRILLIANT GENERAL"}

Previously, the playful usage criticized the role of Industrial's top management in the strategy work. However, this does not prevent a member of the top management from glorifying him/herself as a strategic leader. In the following, the manager shares an intimate account on how he/she and some other members of the management team did some strategic thinking previously:

"For instance, last year we did it quite brilliantly [...] There was a small caucus of five business responsible leaders of the management board and [we] went to [...] Rome for an international seminar [...] When the morning lectures were over, there was a really long two hour lunch break [...] We went to eat sandwiches and asked ourselves, what the morning lectures had told us with regard to our strategy. [...] When we'd been [there] for three days, our summary was that [...] we are right and that we have figured out this strategy in a completely valid way. However, how do you implement it and how do you do it in practice? And that the trend is our friend, but how do you take advantage of it?"

A seminar in Rome, attended by the managers confirmed their faith in the strategy they had formulated for Industrial. They had been doing some reflection at the lunch breaks of the seminar, while eating "sandwiches." They considered themselves to be "right," since they had "figured out the strategy with the completely valid way." Only question to remain uncertain is "how to implement it."

This kind of talk constructs the top managers as very effective; they work during the "really long lunch breaks" not even thinking of having a Mediterranean siesta as one might in Rome. It appears that they will not rest until the strategy is finished. Secondly, this kind of intimate strategy usage constructs them as highly capable of formulating successful and current strategies that are in the forefront of development. It seems that they are already doing what the others are only intending to do. While they have done "a brilliant" job as visionary leaders, now it is time for the pragmatic side of strategy, implementation.

The following extract is an example of how the militaristic macro-discourse can be used as resource in the intimate usage of strategy when discussing the strategy imple- 
mentation. Here the manager describes the strategy work at Industrial in terms of war rhetoric:

"The role of a manager is to see the entirety, the battlefield. And sometimes you have to give resources to the pioneers so that they can build the bridge there beforehand; otherwise we can't cross the river [...]. The execution [of strategy] is like the Finnish offensive against the Soviet Union in the Second World War. It was the boys on the front line who shot the enemies, not the generals."

The war itself does not make this strategy usage intimate, but the context where the war is situated. The manager compares "strategy execution" at Industrial with the Finland's role in the Second World War, which is one of the great narratives of modern Finnish history. The war fought against the Soviet Union is to many Finns a cultural representation of morale, guts, and stout-heartedness in front of a gigantic enemy. It represents a patriotic survival battle that kept Finland independent, although the war itself was lost.

Taking this context into account, comparison of the war fought by Finland and the strategy implementation at Industrial, is a rather brave discursive and rhetorical move. This usage hints that strategy requires the same kind of effort and morale as war. The tactic at hand also makes a distinction between "generals" and soldiers, referred to as "boys on the front line," which is very typical of the militaristic macro-discourse. It is as if the manager positions him/herself among the heroic Finnish generals, commanding his/her troops in the very same war.

The intimate tactic like this might be used for multiple purposes. Firstly, it definitely positions the manager in question as a powerful and capable actor in the strategy work. As a commander or general, he/she is able and capable of seeing the "whole battlefield" and it is in his/her power to give resources to "pioneers" who are struggling on the "front line." It may also be used to glorify the strategy work done in the organization. By comparing it to the war, it seasons the strategy with the discourse of honor and glory related to the military. The strategy usage like this is used to glorify managers. It constructs them as capable and competent to create perfectly valid strategies and to implement them with their troops. Here, strategy is used as an epic narrative that enables managers to build their self image as heroic managers and leaders in it. 


\subsection{2 "WHEN THE OWNER IS LIKE THIS"}

In the following, a manager uses strategy with the intimate tactic when constructing the current ownership of the Industrial. The tone of the usage is disappointed, frustrated and even bitter, to some extent:

"[...] our strategy is pretty, could I say, reformist that would require patient investments from the owner for years. And now, all of a sudden, the owner changed its mind. We are a cash-flow-production-machine since they were unable to sell us. The owner's support, which is very important during a time of a strategic change, is limping at the moment. When this owner is like this, we are not allowed to take risks. Well, what is this strategy for, then?"

This manager would probably not use strategy like this in front of the board of the directors of Industrial. This is a piece of the intimate talk that illustrates Industrial difficult situation. The managers of Industrial have created a strategy that is "reformist" by nature, and hence the company is in a phase of the "strategic change" that would obviously require risk-taking. This is what the manger of Industrial would like to do. $\mathrm{He} / \mathrm{she}$ would like to take his/her company to the next level, but is unable to do it because of the "limping" support from the owner.

Overall, the tactic does not paint a particularly good picture of the owner or "this owner," as the manager puts it. The owner has "changed its mind" suddenly, failed to "sell" Industrial, and is not "supporting" - either consciously or unconsciously - the management of Industrial in its efforts to change the company "strategically." It has turned Industrial into a “cash-flow-production-machine." It is like the company's free will, the capability to determine its own strategic destiny, had been taken from it. It has been subjugated in the will of the owner. The manager is almost like trapped; “what is this strategy for, then?” he asks.

The reference to the machine obviously means the mechanistic discourse, which is used here as a resource to construct and symbolize the current state of Industrial. In this usage tactic, the mechanism is something that is restricting and limiting by nature. It hinders the managers of Industrial from acting in the desired manner, positioning them as parts of the predefined strategy apparatus operated by the parent company. This is interesting since in the (re)production of strategy the mechanism was con- 
structed as a virtue that would ensure the swift strategy implementation and functioning of the company. It seems that the mechanism is constructed as a strength when it can be targeted at others, but as a weakness and limitation when it is targeted at the speaker him/herself.

De Certeau (1988, xxi) uses the example of furnishing a rented apartment as a metaphor to clarify the activity of consumption. The metaphor is very fitting in the case of Industrial because of the prevailing ownership situation. As in the previous extract, the manager of Industrial is operating in terrain which is not his/her own. He/she is living in a rental apartment, the company is in a sense not his/her "own," but belongs to the parent company, which is actually making the strategic decisions instead of him/her. He/she is frustrated with the situation. Although he/she has created the strategy of his/her own, he/she is not able to implement it with a desired manner. In a metaphorical sense, he/she can furnish and re-refurnish the company with his/her strategy as he/she likes. But as he/she does not own the company, he/she cannot fully renovate it according to his/her own plan.

However, although the managers of Industrial live in a rented apartment, why do they want to decorate it with their own strategy? Referring to the previous manager, "what is this strategy for, then?" Maybe it is for maneuvering. Maybe it is a practical ruse to secure the independence of Industrial. Maybe it is the means with which managers show that they still have some power over their organization.

\subsection{3 "YOU DON'T GET HELP AROUND HERE"}

The following talk shows how a manager uses strategy with the intimate tactic, painting a picture of loneliness and a lack of support felt in the strategy work:

"Our plant is out like a snowman [from the strategy process]."

"And starting a conversation here at Industrial is very difficult since you don't have an opponent. [...] The business units are some marketing people."

"[...] we got inputs from the business units, then we got inputs from the steering. It's me who is mainly the only one [who receives this "input"] It's of course nice that this is very independent, this job, when the steering is so incoherent. You get 
to decide pretty much where to go. But actually, you don't get a lot of real help around here. It's actually disturbing, when you don't get help. Such a clear strategy is missing."

One word to describe the previous consumption would be loneliness. The manager is angry and frustrated because of not getting enough support and help in the strategy work. Firstly, he/she regards his/her unit as being an outsider ("out like a snowman," a typical Finnish expression) with regard to the Industrial's strategy process. Secondly, having "a conversation" seems to be hard for him/her since he/she lacks an "opponent" to talk to. Obviously, the people working in the business units are not appropriate opponents since they are all "marketing people." The manager also gets a lot of direction and "steering" from different sources, but is lacking "a clear strategy" and thus feels him/herself lonely when not getting enough "help."

When in the instrumental usage, managers literally use strategy; here the manager constructs him/herself as a lonely rider, who is being used by the strategy. He/she feels left alone. It seems like he/she is dwelling in a foreign city that he/she neither knows nor has a map of. The humanistic macro-discourse is brought into the play when the manager discusses the lack of "help" and support. They refer to the needs of an individual. And finally, the pragmatic macro-discourse can be spotted in the desire for a "clear" strategy. The comment can also be read as a reference to the spiritual macro-discourse, since it discusses the issue of belonging to the wider entity, which the manager is clearly lacking here.

\subsection{4 "I'VE NEVER BOUGHT THE STRATEGY"}

The intimate tactic is also used for describing how the current strategy of Industrial does not match some parts of the company. The following extract shows how a manager of Industrial reveals what he/she actually thinks of the company's strategy:

"I've never bought the strategy; neither will I buy it today. But then again, I think that maybe I can live with it, since it doesn't influence this business a lot. Well, okay, this time."

The manager has not "bought" the strategy of Industrial. Here, buying is used as a synonym for adoption or acceptance of the strategy. "Never" refers to a rather strong 
statement made by the manager, hinting that this particular strategy has never been the favorite of his/hers, and nor will it be, since he/she does not have any intention of buying it "today." This kind of strategy usage is very intimate by nature. It is likely that this particular manager would not use strategy like this in front his/her own supervisor or in front of the other managers. It almost sounds like he/she would secretly disassociate him/herself from the corporate strategy to wander his/her own paths, in de Certeau's terms.

However, the manager seems to know that a complete separation is not possible for $\mathrm{him} / \mathrm{her}$. He/she is still a manager of Industrial, who is expected to preach the gospel of strategy. However, he/she states that he/she "can live with" the strategy, since it “doesn't influence" his/her "business a lot." Here, strategy is something you can live with, but which you do not necessarily have to adopt or accept. It is almost treated like an instrument (like in the instrumental tactic), but this instrument is rarely used. The strategy does not influence the manager's business a lot, which is good from his/her perspective.

In the following, the same manager uses Industrial's customer approach strategy as a something to dis-identify from:

\footnotetext{
"We are in the state, where we have a sort of an intermediate phase strategy [...] We clearly noted that we don't understand what our customers do and what they want. So, we are unable to formulate a customer approach strategy yet. [...] At this time we are a grocery store."
}

According to the manager, his/her unit is "unable to formulate a customer approach strategy" because it is a "grocery store" by nature. The term "grocery store" is used here as a contrast to customer-approach thinking. The manager is leading a unit that does not "understand" what their customers want and is thus unable to provide customized tailor-made solutions to them. Here the manager uses strategy as a target to dis-identify from. He/she constructs it as something that is by far unfitting to his/her unit and is thus something to avoid. The comments could be read as references to the pragmatic macro-discourse. The first comment reflects a practical coping with the strategy, and the latter show how the coping is done in practice. 
In this chapter, I have shown how the managers of Industrial have (re)produced the strategy as a management discipline and then used it tactically for their own purposes. Both the (re)production and usage of strategy used the macro-discourses of strategy as resources in this process. The strategy (re)production and usage and the macrodiscourses related to them are summarized in Table 9.

TABLE 9 STRATEGY CONSUMPTION AT INDUSTRIAL

\section{N D U S T R I A L}

\section{(RE)Production Usage}

Strategy is a way or means to reach the vision or to win the war. (Spir \& $\mathrm{Mil}$ )

Strategy is created and executed through the systematic strategy process. (Mec)

Strategy concerns the entire personnel. (Hum \& Prag)

\section{Instrumental:}

Managers use strategy to analyze and understand their business. (Hum \& Mec)

Managers use strategy to set targets and objectives. (Mec)

Managers create sub-strategies to secure and ensure that their unit is in line with Industrial's strategy and appears legitimized. (Hum \& Mec)

Managers use Industrial's strategy as a loose framework, guideline, which leaves them room to maneuver with their own sub-strategies. (Prag)

Playful:

Managers question and joke about the role of Industrial's headquarters and top management as central strategists. (Mec \& Spir)

Managers play with the cultural differences between different parts of Industrial, preventing it from operating coherently and realizing its strategy in a desired way. (Prag)

Intimate:

Managers use strategy to glorify themselves as strategic leaders. (Mil)

Managers outline how they lack support in Industrial's strategy process. (Hum \& Prag)

Managers dis-identify themselves from Industrial's strategy, which does not concern them. (Prag) 


\section{POLYTECHNiC}

In Finland, higher education is provided by universities and polytechnics. While the universities have a long history in Finland and their status as higher education providers is institutionalized and strong, the system of polytechnics is still fairly new. The first polytechnics started to operate on a trial basis at the beginning of the 1990's. The polytechnics are practically oriented and they train professionals in response to labor market needs and conduct research and development that supports and promotes regional development, in particular. Polytechnics award professionally oriented higher education degrees (mainly bachelor's degrees), which take 3.5 to 4.5 years to complete.

My second case organization, Polytechnic, is a multi sector polytechnic situated in a major Finnish city. It was established in the late 1990's when different institutes of higher education maintained by the city were merged. Polytechnic is funded by the Finnish government and the City. The Government allocates resources to it in the form of core funding that is based on unit costs per student, project funding, and performance-based funding. Polytechnic also has some external sources of funding.

Although Polytechnic operates under the City Council and the Ministry of Education, it has autonomy in its internal affairs and it is managed by a board and a rector. The board members consist of staff, students, and business community representatives. The daily management of the organization is handled by the management team that consists of the rector, two vice rectors, faculty heads, and support function managers. Polytechnic is divided into three faculties, based on their teaching fields. The faculties are further divided into degree programs, of which there are dozens. The activities of Polytechnic are situated on different campuses around the City, and the faculties run 
their education programs rather independently within the common frames, aims and regulations provided by the board and the Ministry of Education.

The culture of Polytechnic is characterized as "bureaucratic" and inflexible by some, caused by the city administration and labor unions. Polytechnic is also characterized by many as "a young organization.” It seems that since its beginning, Polytechnic has undergone constant change. There have been lots of changes in its structure and even in the legislation that governs its activities. Some managers are afraid that the constant changes cause too much stress for the teachers and other staff and turn competent employees away. Some claim that the decision-making procedures are somehow blurred and that no-one is willing to take responsibility for the decisions that have been made at Polytechnic.

The management board of Polytechnic plays a crucial role in its strategy work. Like at Industrial, strategy work at Polytechnic also follows a certain systematic annual strategy cycle that includes milestones and tasks related to strategy. This process is owned by a development manager working under the rector. Once the strategy for the whole organization has been created, the faculties create their own sub-strategies based on it. Polytechnic's strategy cycle has a close link to the budget cycle of the City Council, and Polytechnic is thus obligated to produce certain strategic plans that are discussed and reviewed at the City Council. In this way, the strategy is a sort of institutionalized must for Polytechnic; it is required by the financiers, legislators, and other authorities.

However, it seems that the human relations between the members of the board are rather tense. There is apparently discord between the faculty heads and central administration managers. The faculty heads criticize strategy-making for being overly administration-driven. Although they have attended the strategy-making sessions, they have noticed that the final outcomes are quite different from those agreed in the planning sessions. In de Certeau's terms, they operate here in terrain which is not their own. The central administration managers represent the administration of Polytechnic, and according to faculty heads, this "central kitchen," as they call it, tries to dominate everything, including them. In contrast, faculty heads represent the voice of the field work hard to secure and defend their limited resources and focus on running their own faculty. On the other hand, the administration managers claim that the faculty heads oppose all "coordination" that they are trying to provide. As a consequence, the at- 
mosphere in the strategic planning sessions has been poor. This schism between the center (administration) and periphery (faculties) of the organization is similar to Industrial's situation in some ways.

\subsection{STRATEGY (RE)PRODUCTION}

The (re)production of strategy seems to follow two paths at Polytechnic. The first stream (re)produces strategy as an agreed contract or "vision" between the personnel of the organization. In other words, it (re)produces strategy as a humanistic phenomenon that requires the participation and involvement of the whole personnel and emphasizes Polytechnic's nature as an expert organization. Secondly, strategy is constructed as something very pragmatic that should be taken to "the grass roots." Here, the strategy (re)production gets a strong practical emphasis drawing on the pragmatic macro-discourse of strategy.

\subsubsection{TOOL FOR REALIZING VISION}

To begin with, this is a sample of the (re)production from the manager of Polytechnic. In this case, strategy means clearly a vision for him/her:

"Well, for such a professional manager, they [strategies] are the most crucial tools. You must have the most inspiring vision. [...] And in order to realize the vision, sorts of actions are derived from it, strategic ladders that are climbed up into the vision."

Here the manager constructs him/herself as a "professional manager." For such a manager strategy is "the most crucial tool." For what is this tool used? Strategy means "the most inspiring vision," which is a reference to the spiritual discourse. Again, mechanism is brought into the play. Firstly, the word "tool" hints at the mechanistic discourse as well as the "strategic ladders" along which the vision is to be reached. Also the actions are "derived from" the vision. The mechanistic macrodiscourse is used here as a resource to add systematic flavor to otherwise spiritual comment, which talks about "vision." 
Here, the strategy (re)production is similar to that of Industrial in many ways, which is why I will deal with it rather quickly. Instead, I will focus on the next feature of (re)production, which regards strategy as an agreed contract within Polytechnic.

\subsubsection{AGREED CONTRACT}

The following dialogue produced in a pair interview by two managers of Polytechnic reveals an interesting struggle between the spiritual and humanistic macro-discourses.

\footnotetext{
"Strategy as such doesn't exist before there's a sort of goal, vision. [...] Not until we all have a sufficiently unanimous picture of where we are going can we understand those strategic actions and decisions. [...] In my opinion, the strategy is a set of road signs."

"The whole personnel have to be involved in it."

"Yes, probably the personnel will get involved in it, but on the other hand, I think it's the management's responsibility [...] A reasonable set of road signs [...] how to proceed. [...] The management needs to have wisdom to do it reasonably."
}

"But let's say that us, the whole personnel, should be able to see the common destination, because then you can get committed into those strategic targets."

"I think everyone has a bit same problem [...] strategy can't only belong to the management. I think that the management is responsible for it, but, indeed, it really has to belong to the whole work community."

In the beginning of the dialogue, the whole existence of strategy is said to be conditional on the "vision." This "unanimous picture" is required before the "strategic actions and decisions" are understood thoroughly. In a journey to the vision, the strategy is "a set of road signs." This is clearly a spiritual rhetoric derived from the spiritual discourse. The management is (re)produced here to be in a responsible position liable for the direction. It almost seems that they are messianic leaders, who are leading their people to the Promised Land, a "common destination." This duty of setting "reasonable road signs" for others to follow requires "wisdom." This rhetoric reveals 
the rather managerialistic nature of the spiritual discourse. It constructs managers as both wise and capable of leading the way for the others to follow.

On the other hand, the humanistic macro-discourse is also intensively present in the dialogue. The success of strategy requires the involvement of the "whole personnel." Strategy cannot belong only to the management, but has to belong to the whole work community, which is agreed by both managers. Here, strategy is constructed as some sort of shared vision. The humanistic macro-discourse is present here in a purer form than it was in the case of the Industrial's strategy (re)production.

The following comment from a manager of Polytechnic brings in the pragmatic discourse along with the humanistic talk:

"I actually read the strategy as a sort of shared contract here within the polytechnic.[...] But then, I have thought that somehow it should be made a common operations model, how it is taken to every level."

It is as of the manager suggests that the "shared contract" of strategy is not enough until it is taken to every level of the organization. Also, mechanism is present here when the manager states that strategy should be made "a common operations model."

\subsubsection{EVERYDAY DECISION-MAKING}

The instrumental strategy (re)production at Polytechnic also has a very pragmatic emphasis. The next example outlines how the strategy should be considered when making decisions:

"I think that in the case of every decision making situation, we should reflect whether this decision leads in the right direction. Strategy isn't realized as such, but it's like the guidance of the everyday action."

The first comment is a piece of the pragmatic macro-discourse at its purest. According to it, the strategy should always be taken into account when decisions are made. This is how it "guides everyday action." The first comment is also instrumental in the sense that it respects and adopts the spirit of the strategy instead of challenging it. Strategy literally "guides" action. The pragmatic macro-discourse is also used here as a resource to highlight the practical nature of Polytechnic's strategy. It suggests that 
the strategy should be considered to reflect "whether the direction is right" in every decision-making situation.

Here, the pragmatic macro-discourse is used for the first time to take the strategy out of the platform and bring it to the "everyday" life of the members of the organization. What is also interesting here is the idea of how strategy is realized in the everyday actions of the people, and not as a separate matter.

The strategy (re)production discussed earlier describes what strategy is and/or what it should be. At this point, we know how strategy appears to the managers of Polytechnic. Next, we will turn our attention to the usage of strategy by studying how the managers use strategy instrumentally, playfully, and intimately.

\subsection{USAGE: INSTRUMENTAL TACTIC}

The instrumental strategy usage at Polytechnic follows three different lines. Firstly, the managers of Polytechnic write strategies for the City Council and other stakeholders to report and legitimize their activities. Here strategy is used as a separate policy-making procedure that does not have too much to do with the actual everyday work activities of the organization. Secondly, managers create strategies for improving and polishing Polytechnic's brand for the public, thereby aiming to differentiate Polytechnic from its competitors. And thirdly, managers use strategy in their own units for their own purposes and intentions. This category represents internal strategy usage at Polytechnic.

\subsection{1 "ElEgant STRATEgy PAPER"}

Polytechnic works under the Government and the City Council, who oversees and finances its activities. The faculties of Polytechnic are coordinated by the management board of the organization and the central administration, and the degree programs are controlled and steered by the faculties. It seems that at the Polytechnic level, strategy is used as a policy-making project to report and legitimatize its activities to the City Council, and the same spirit seems present in the faculties and degree programs. In the 
following, a faculty manager describes how Polytechnic's strategy work is done annually:

"We have tried to systemize this job [strategy] quite far. [...] There's an annual cycle according to which certain things related to the strategy are done. [...] And partly this thing is also controlled by the budget cycle of the city. [...] We need to have certain plans at certain time of the year ready to be taken in city's direction. And of course, it also defines those phases where strategy is reviewed. And not only the strategy review, but also the results are evaluated. [...] At the moment, we have maybe created more plans."

Polytechnic's strategy work is here described as a "systematic" procedure, or "job," as the manager calls it, and that proceeds through the annual strategy "cycle." This cycle seems to have a close connection to the procedures and timetables of the City Council, especially "budgeting," which defines when Polytechnic should do "certain things." As a consequence, Polytechnic is obligated to produce documents for the City Council, which reviews and evaluates its strategy and performance based on them.

Strategy is clearly a tool for the managers (and Polytechnic) to report and legitimize their activities for different stakeholders. This kind of strategy usage represents bureaucratic strategy usage in its purest form, which is done because of obligations and official rules. References to the mechanistic macro-discourse are also apparent in expressions such as "systematic" and "control" that refer to the formal and methodical style of doing strategy.

However, it seems that the faculties imitate this manner of creating strategies and produce the same sorts of strategy papers for themselves. In the following, a manager tells how a strategy was created in his/her faculty:

\footnotetext{
"We sat several days [...] Then we produced the similar papers for the faculty, strategy and scorecard [...] I think that it took too much time because it lasted more than a year all together."
} 
In the following, the same manager tells what happened to the strategy he/she described previously:

"Strategy is a focused operations model. The structure and the vision [...] are related to it. During this period, strategy was built quite forcefully, and then it cascaded down step-by-step. But you could say that this fine construction has been buried under the organizational change [...] The strategy has actually sort of disappeared. In a way, it appears that there's no clear policy that would have been followed."

Two previous comments highlight one way of using strategy at Polytechnic. The instrumental tactic constructs strategy as a rather massive policy-making project done every once in a while by the managers of Polytechnic. The result of this project is strategy "papers." These papers set a "vision" and "focused operations model" for the rest of the organization to follow. However, in this case it seems that this paper has been "buried" under other things such as the "organizational change." This is interesting, since in many cases it is the strategy that dictates organizational change, and not the other way around as seems to be in this case. Nevertheless, at Polytechnic the strategy has "disappeared" and consequently there is no "clear policy to follow" anymore.

But why are these strategy papers drafted if they do not guide the actions of Polytechnic? Maybe they are made to legitimize its activities for the City Council, legislators, and other stakeholders. It seems that when you have "strategy papers" you are a legitimized and taken seriously as a player in the educational field. In the previous comments, the manager does not, however, seem to complain although he/she thinks that strategy making took too much time - "over one year."

The previous usage style is also an example of merging several different resources together. The mechanistic discourse is present when talking about the "scorecard," "operations model," and "structure." The manager also mentions how at the beginning the strategy "cascaded down step-by-step" in the organization. The spiritual discourse is used in the form of "visions" and "following." And, the pragmatic discourse is also present at the end of the comment when the absence of "a clear policy" is brought up. 
The following comments shed more light on how strategy work is done at Polytechnic. In the next quote, the manager makes a distinction between strategy and operations:

"You easily get the idea that strategy work is done because it's so elegant [...] I think that there are two different things. There's operative activity and there's strategy.”

In the next account, another manager complains how he/she has separated strategy from other activities:

"Why I'm at least partly dissatisfied with my own activity is because the strategy work is a little separate box and these others have then been the other box."

The previous comments illustrate how strategy work at Polytechnic seems to follow its own logic and operative activities their own. Strategy work seems to include some sort of glamour or "elegance," as the first manager highlights. This talk can be labeled as pragmatic, since it requires strategy to be more practical by nature. It also indirectly suggests that strategy should not be separated from the other activities of the managers.

\subsection{2 "IMAGE BUILDER"}

As mentioned above, the whole system of polytechnics is a rather new in Finland. And because there are several different providers of higher education in the City, where Polytechnic is situated, it competes with them for the best students. That is why the managers of Polytechnic use strategy to clarify and crystallize Polytechnic's image for the public, as the following example shows:

"We have already succeeded quite well in image building [...]. You see that it wasn't useless, the strategy, to clarify the image. The search for students and all this proves that we are known and that this polytechnic system overall is so new that we have a lot to do so that we can differentiate from this big mass of educators."

Polytechnic is in the business of "image building" with the aim of "clarifying" its image for the public. The manager sees that the effort put into this has not been 
wasted; vice versa it has been proved that it pays off in attracting students. Polytechnic has become "known" in the eyes of the public, which seems to be good, since there is a "mass of educators" that provides similar kind of education to that offered by Polytechnic. What is interesting here is that the strategy is used as a tool in promoting and clarifying Polytechnic's image and reputation. The manager also adds that more needs to be done in order to "differentiate" Polytechnic from the "big mass of educators."

The previous quote could be read as a sign of the pragmatic macro-discourse, since it follows a pragmatic spirit by aiming to clarify things for the public with the help of the strategy. Compared with the (re)production of strategy, strategy is used here in a rather creative and unexpected way. Strategy is no more an internal, agreed vision that guides the activities of the organizational members, but more likely something that is used for external purposes. Here, strategy appears as a fancy marketing device that managers use to attract desirable students and partners. Maybe strategy also appears to them as a marketing policy to follow.

\subsection{3 "STRATEGY - AT OUR OWN LANGUAGE"}

As mentioned earlier, the general strategy of Polytechnic is further translated into faculty-level strategies and plans by the faculty heads and their management teams. This is an interesting phase of Polytechnic's strategy process, since here the faculty managers play a crucial role in translating and crystallizing the strategy for their units. The following account describes how a manager of Polytechnic tries to concretize Polytechnic's strategy in his/her faculty at this phase of the strategy process:

"Our success as a faculty here within Polytechnic is based on the fact that we have taken the strategies into the grass roots most consistently. These [strategies] say people nothing. I'm the [...] direction that is trying to take care that we would act according to the strategic objectives. We are trying to crystallize and explain the things Polytechnic is aiming at in our own language. And my duty is to see that Polytechnic's aims are realized. But the ways of realizing and destinations are such that our people can commit themselves to them from the bottom of their hearts." 
The comment portrays a manager that is leading his/her faculty actively by translating the Polytechnic level strategy, which "says nothing” as such, to his/her own "people." This requires that the strategy is translated and "explained" in their "own language." Although the manager outlines that it is his/her "duty" to see that Polytechnic's strategy is followed in his/her faculty, it seems that he/she might also take some liberties while translating it to his/her staff. As the strategy itself does not say anything, he/she restates it in a form that touches his/her people. They commit to it "from the bottom of their hearts."

"Heart" is used here as a metaphor for deep commitment. It describes the deepest motives and intentions of an individual, and in this case the manager is willing to win his/her people's hearts. This is rather strong rhetoric. The rhetoric has its roots in the spiritual discourse. Here, the manager appears as a charismatic leader, who is willing to touch his/her people's inner world with the strategy, aiming to change the course of their life. It is obvious that it is not Polytechnic's strategy that would have such an impact on the people, since it is trivial and empty by nature, but it is the manager him/herself who translates the strategy into such an inspiring and powerful asset. This might be read as a reference to the manager as a chosen leader. Also, the pragmatic macro-discourse is present in the manager's comment. His/her unit's "success" is based on the practical view of the strategy of consistently taking it to the "grassroots."

This kind of instrumental strategy use plies strategy as a loose framework, which allows managers to use it quite independently for their own purposes. By tuning and shaping it, they re-create it and make it habitable for their units in a way that suits their ideas and thinking.

\subsection{4 "PROBLEM SOLVER"}

While the previous extract showed how managers might use Polytechnic's strategy as a slack framework to create their own strategies to inspire people, here strategy is used in a more pragmatic way. In the following, a manager describes how strategy is used in his/her unit: 
"The objectives of our faculty are derived from Polytechnic's common objectives. And especially, the reporting that we go through annually, and we try to specify the objectives and try to agree on the metrics [...]. In a way, those Polytechnic strategies are being translated in a catechistic way [...]. And of course, different faculties have different kinds of problems. The biggest problems in our faculty are the dropouts. [...]. And in that respect, the strategic objectives related to it [...] are considered to be the most important by us. Again, [other] faculties have some other things."

At the beginning of the quote, the manager describes how the objectives of his/her unit are derived right from Polytechnic's strategy. The metrics used to evaluate the objectives refer to the mechanistic macro-discourse of strategy. Also the spiritual macro-discourse is used when the manager describes how Polytechnic's strategy is translated to his/her unit "in a catechistic way." However, the main emphasis is put here on the rest of the quote, where the manager describes how strategy is used as an instrument to solve a problem particular for the manager and the unit in question, "dropping out." The manager uses strategy to set "strategic objectives" related to that particular problem and these objectives are considered to be the most important in his/her unit.

This example is a piece of the instrumental strategy usage that also departs from the (re)production of strategy. This kind of strategy usage is not visionary by nature nor does it seek to have an impact on people, on the first hand, but more likely focuses on the everyday struggles of an organization. Strategy is used to solve a problem and cope in the current situation.

\subsection{USAGE: PLAYFUL TACTIC}

The emphasis on playful strategy consumption at Polytechnic is rather critical and has two main targets. Firstly, it is used to criticize the poor quality of Polytechnic's strategy. Secondly, Polytechnic's administration-driven strategy work and its mechanisms are criticized in a satirical manner. It seems that the playful strategy usage is largely due to the schism between Polytechnic's administration and faculties, and it is mostly the faculty heads that target playfulness in Polytechnic's strategy and strategy work. 
This may indicate that they have no other choice than to joke and amuse them with the entire strategy.

\subsection{1 "HAVE YOU EVER SEEN ANYTHING SO MISERABLE?"}

The playful tactic criticizes the content of Polytechnic's strategy. In the following a faculty manager shares his/her thoughts about it:

"It's quite hard to find strategies that would have a significant guiding importance. A paper flavor tends to remain in them, [they're] really miserable. Have you ever seen anything as miserable as our strategy? They don't tell people anything."

"I believe that the most [of Polytechnic's staff] are thinking that this kind of strategy we have at Polytechnic won't get realized. It's somehow unrealistic and like somewhere from Ufoland."

This playful rhetoric is based on the spiritual macro-discourse. According to the manager, Polytechnic's strategy is so "miserable" that it does not have significant "guiding" importance for the organization and its people. As instrumental consumption outlined the role of strategy as a guiding principle, here the playful tactic makes satiric remarks about its quality. Indeed, Polytechnic's "unrealistic” strategy would appear to be from "Ufoland."

In the next quote, the same manager brings out how strategy creation at Polytechnic has been an exhaustive process and taken a lot of time and effort:

"We've had such situation here that this strategy work has actually never ended here. This has been forced for two years now and several shelves have been filled with different kinds of papers in which strategy is changed back and forth.

With that respect, communicating it [strategy] has been difficult because you haven't known what the final version is."

While the instrumental tactic consumed strategy as a massive policy making project aiming to produce strategy papers, here it is joked about playfully. "Several shelves have been filled with" different kinds of strategy papers and the strategy work seems to travel back and forth. The manager considers strategy communication "difficult" 
because he/she does not know what the final version of strategy actually is. This kind of strategy usage is targeted against the content of Polytechnic's strategy and the process where it was created and formulated.

\subsection{2 "RIDICULOUS ADMINISTRATIVE SYSTEMS"}

The following comment is a hilarious example of playful rhetoric using satiric talk to build a point of view:

"The rewarding system and strategy have no sufficient connection. That's a pretty big problem, in my opinion. Whether you do it or not, you always get a sanction. Or those who don't, they never get sanctions. And those who prevent strategy from being realizing, in fact they get rewarded."

This is a mechanistic talk in a sense that it discusses the systems and procedures related to the strategy. The manager criticizes the missing connection between the strategy and rewarding by joking about the rewarding criteria. Here, contradictions are used as rhetorical resources: the manager says that "you always get a sanction." $\mathrm{He} / \mathrm{she}$ also adds that those who "prevent strategy from being realizing" are rewarded. In other words, he/she says that there is no benefit from realizing strategy in one's work. Instead, you may be better rewarded if you do not follow the strategy.

In the following example, a middle manager outlines how different strategic practices are imposed on him/her and how the managers are obligated to use them although they do not find them useful. The strategic practices are consumed in a very critical manner:

"[...] we have the EFQM, clearly a system taken from the industry [...] It's suitable for a sausage factory [...] People take evaluation like 'OK this is a kind of bullshit again, let's fix this now' [...]. Those indicators are ridiculous. We laugh at them once we write them down. It makes no sense at all that the management of Polytechnic gives us strategic targets, and then there's these foolish metrics. [...] We laugh our heads off at them but we still do it."

Here, the playful criticism is targeted at the quality system EFQM, which is used at Polytechnic to produce review data. The manager seems to find this system rather irritating and obviously inappropriate for Polytechnic. The system, following her words, 
is suitable for "a sausage factory," not for the polytechnic. This is a lively comparison. Sausage factory is used here to illustrate something totally different than Polytechnic. It says that Polytechnic is not a production factory, but a professional organization that operates with anything but mass production logic. However, it is reviewed with mechanisms that are adopted from industry.

This statement also constructs Polytechnic's management in a pretty ridiculous light. The system at hand is theirs, and not that of the middle managers, who are "laughing," and thereby showing disrespect and a lack of confidence in the management when forced to use "the foolish metrics." While "people" are forced to participate in the evaluation they consider it "bullshit." This kind of rhetoric is clearly used for the purpose of carnevalization. It seeks to criticize the Polytechnic administration and make fun of it.

\subsection{USAGE: INTIMATE TACTIC}

The intimate strategy consumption at Polytechnic is used for three purposes. Firstly, it highlights how the managers are quick to ignore the strategy if they consider it inappropriate. Secondly, the intimate usage tactic reveals how the managers use some "semi-illegal" tricks to cope with it. And thirdly, intimate consumption discloses some internal contradictions present at Polytechnic that hinder its strategy work.

\subsection{1 "IT'S LIKE A SEMI-ILLEGAL ACTION"}

In the following, a manager of Polytechnic describes a practical ruse that he/she has done when coping with the strategy. This is an interesting notion of intimate talk. The manager reveals something that would get him/her into trouble if it were to be made public. While confessing something intimate about his/her activity in the strategy process, the manger also constructs his/her identity and subjectivity.

"It's like a semi-illegal action that you can enable something. [...] Our resources to do it, well we don't actually have them. Then, we have to build those resources sort of semi-illegally from the educational recourses. [...] So, then I internally rig and build those recourses there. And I'm not allowed to make a 
public announcement of it, because otherwise I would get an admonition. [...]

But I hope that this won't end up in there [report], since I would get caught."

The manager has taken action that he/she characterizes as a "semi-illegal" in Polytechnic's strategy process. If he/she were to be caught red-handed, he/she would get an "admonition." And this is just "an example" of the kind of activity which hints that this kind of action is not an individual case but more likely activity that is vital accomplishing things the proper manner. This activity is resistance against the current structures of Polytechnic. However, it is silent resistance; creative usage that takes place in the midst of Polytechnic and obeys the official rules or procedures. It almost sounds like this kind of activity is obligatory, an everyday practicality needed to cope with the strategy.

In the following, a manager of Polytechnic seems to be speaking in the same tone:

"We have a desire to work in a certain manner that would support our strategic targets. Some pretty rigid bureaucratic operational modes are related to the city organization. In practice, they prevent us from working smartly. It's related to the central sectors of the polytechnic, that is, the external cooperation. [...] Let's say that if you want to act in a way that the partners don't regard as odd by us, then you have to do something that's actually not permissible. But then afterwards, you notice that was quite wise to do so."

The mechanistic discourse is used here as an obstacle for the managers to act according to the strategy. "Bureaucratic operational modes" prevent "smart" action. In order to act in a way that is socially acceptable to the "external" partners, you need to act in ways that are not "permissible" by the organizational rules. This account constructs a contradiction between the strategy and Polytechnic's structure. These structures almost disturb the individual, making him/her look ridiculous and "odd" in the eyes of external partners. Here managers are like lonely riders who are trying to survive in the midst of the system. They compete against the system. They perform clever tricks to outsmart the strategy system. They bend the rules and take some risks. However, they do not make too much noise about it, otherwise they would end up in trouble. 


\subsection{2 "SIDELINED AND INTIMIDATED"}

The humanistic accounts in the strategy (re)production outlined the nature of Polytechnic's strategy as "a shared contract" among the personnel of the organization. This ideal of unity is questioned here, as the managers of Polytechnic describe how they have been mistreated in the organization's strategy process. In the following, a faculty head gives an account of how he/she was persuaded to use the strategy:

Of course I know it [Polytechnic's strategy] quite well, because I have had to swallow it. [...] Probably some persons of the management, who have been responsible for the strategy process, say that it has been the management team that has created it together. But is has been shoved down your throat, given to you ready-made. You have learned here over the years that they are not worth questioning. You'll just get revenge for your faculty."

This intimate rhetoric describes how the strategy has been forced on the manager, "shoved down" his/her throat, as he/she puts it. The manager also hints how the parties responsible for the strategy process may give a false idea that the strategy has been done "together," while it has actually been provided "ready-made." The quote becomes even more grotesque when the manager says that the opponents of strategy will get their revenge if they dare question the strategy.

In the following, this idea is supported, when another faculty head gives an intimate description of his/her and his/her colleagues' role in Polytechnic's strategy work.

"Faculty heads, who are involved in it [strategy work] kind of alongside their actual management duty [...]. Preparation has been done at the development unit. So, maybe there have been some contradictions and, of course, the personal relations haven't been [the best ones]. So, maybe it has disturbed and interrupted the [strategy] working. It has been pulled too much from one direction. [...] The other faculty heads are exactly in the same situation. They haven't had so much time to invest in this [strategy work]. And thus the ones responsible for creating the strategy, they have not just taken care of it, but have also taken it in their own direction." 
In the following, the same manager continues the previous thoughts:

"That whose voice is heard there mostly? It hasn't been any from the faculties but other participants [...]. It's related to personal chemistry, that the work atmosphere hasn't been the best possible. [...] There's been quarreling [over the strategy]. Although I feel that I haven't participated in it. [...] Confrontations between people have disturbed the [entire strategy] working."

Here, the humanistic discourse is consumed as a means of describing the poor "personal relations" of Polytechnic's top managers and the role of the faculty heads in the strategy work of organization. Humanism is present in this talk through the words such "personal relations" and "personal chemistry." Clearly, strategy is a task accomplished by humans through their mutual interaction. However, in this intimate talk the interaction does not work in the desired manner. It seems that there are "confrontations" and some "quarreling" over the content of the strategy among the managers. The poor "personal relationships" among the top managers interrupts and disturbs the strategy work done in the organization. The faculty head also complains about how his/her and his/her colleagues' contribution to the strategy, the contribution of those who are "involved" in strategy work "alongside" their actual "management duty," has somehow been ignored. The administration, and in this case "the development unit," has taken care of the strategy work and its preparation and also taken the strategy "to their own direction." This seems to irritate the faculty heads who are all in "exactly" the same situation, according to the manager. The strategy "has been pulled too much from" the development unit, it is their "voice" that dominates the strategy work.

What is also interesting in this account is how the manager describes strategy as something that the faculty heads do "alongside" their actual management duty. So, strategy is not their management duty, but some separate part of it. It almost sounds like strategy is their hobby. This intimate talk is used to portray strategy as something the administration of Polytechnic is doing instead of the faculty heads, who are more or less bystanders in this process. Here, strategy is manifested to managers as a source of intimidation and sidelining. They are no longer capable of using it as an instrument nor will they joke about it, since they have been almost hurt and offended in the strategy work. 


\subsection{3 "IT'S LIKE SOME STUPID THING"}

Strategy (re)production constructed Polytechnic's strategy as a sort of an agreed contract within the organization. In the following, a manager of Polytechnic describes how he/she takes strategy. It appears that this strategy contract does not include $\operatorname{him} /$ her.

"If there's some [strategic target] that doesn't suit [me], I don't necessarily care about it [the target]. We don't have any sort of supreme strategy controller here that would control. [...] For me, it's not a big problem, since I just don't react to it [strategy]. It's like some stupid thing."

This is rather strong intimate strategy consumption. The manager, drawing on the mechanistic macro-discourse, passes the strategy and its relevance for his/her skillfully. Mechanistic discourse is present here, when the manager mentions the "supreme strategy controller" that does not control the execution of strategy at Polytechnic. Due to this, when strategy does not "suit" him/her or his/her unit, he/she does not "care about it." The manager also reveals that for him/her strategy is a "stupid thing." This comment paints a picture of an organization that does not care too much about whether strategy is taken seriously. Here, the strategy does not concern the manager. He/she is above strategy, and not affected by it. He/she constructs him/herself to be free as a bird and strategy as a problem that does not include him/her.

This chapter has discussed how the managers of Polytechnic have (re)produced and used strategy with the means of the macro-discourses of strategy. The strategy (re)production and usage and the macro-discourses related to them are summarized in Table 10. 


\section{TABLE 10 STRATEGY CONSUMPTION AT POLYTECHNIC}

\section{P O L Y T E C H N I C}

\section{(RE)Production USAGE}

Strategy means realizing the inspired vision. Strategy is ladders or road signs that lead to the vision. (Spir $\& M e c)$

Strategy, as an agreed contract, requires participation and involvement of the entire personnel. (Hum)

Strategy is pragmatic and should be taken to the grass roots, where everyday decisions are made. (Prag)

\section{Instrumental:}

Managers produce elegant strategy papers for the City Council to legitimize and report the organization's activities as an administrative task. (Mec, Spir \& Prag)

Managers use strategy to differentiate Polytechnic from its competitors and improve its brand. (Prag)

Managers use strategy to build commitment and involvement in their own units. (Prag, Hum \& Spir)

Managers use strategy to solve problems in their own units. (Mec \& Prag)

Playful:

Managers regard Polytechnic's strategy as poor in quality. (Spir)

Managers construct administration-driven strategy work and its mechanisms as unsuitable and ridiculous for Polytechnic. $(\mathrm{Mec})$

\section{Intimate:}

Managers take risks and use semi-illegal tricks to cope and maneuver with Polytechnic's strategy. (Prag \& Mec)

Managers feel themselves intimidated, sidelined and dominated in Polytechnic's strategy work. (Hum)

Managers pass and ignore Polytechnic's strategy swiftly when considering it unsuitable for themselves. $(\mathrm{Mec})$ 


\section{INSURANCE COMPANY}

Insurance company (henceforth Insurance), my third case organization, is a Finnish service organization that provides a wide range of insurance services to its customers in different customer segments. The services are produced mainly at the headquarters of the company, while market operations like marketing, selling and customer service are conducted by the customer service organization spread across the business area. Although Insurance is known in the industry for its rather conservative growth strategy, the recent years have been financially very successful for it. During the last 18 years, the company has improved its profit record annually. Thus, some are afraid that this unparalleled success might have made people feel too "comfortable," which may prevent further changing and development.

Many employees of Insurance call its culture participatory and conversational by nature. People actually call it a "Swedish" organization, referring to a common belief that Swedish organizations are by nature participatory and democratic. Being conversational means that there are lots of different meetings and forums at Insurance and its decision-making tends to be consensus-driven. However, some argue that there is too much discussion and participation in Insurance, causing slowness and inefficiency.

Insurance has a reputation for being a good employer. The firm tops the Best place to work charts regularly. The saying goes that it has never laid people off for financial reasons. Although it may not pay the best wages in the industry, it provides some fairly generous job-based benefits to its employees, according to some managers. At Insurance, jobs are lasting and many people have worked for the company all their working life. Overall, people seem to be satisfied with working for Insurance. 
Like at Industrial and Polytechnic, strategy-making at Insurance is driven by the company-wide procedures, consisting of a strategy process that is structuring and scheduling strategy-making, and a strategy workbook that advices executives on how to create their own unit-specific strategies. Because of the company structure, many strategies co-exist in the organization simultaneously and the procedures aim at congruence between them.

Insurance's strategy is created for a three-year span, although it is reviewed every third month by the top management to find out whether it is still valid. After the corporate strategy has been created, Insurance's subunits and companies create their own strategies and plans based on it. After the strategies have been devised, they are realized and assessed with the Balanced Score Card method. This kind of company-wide strategy process at Insurance is considered both a strength and a weakness. On the one hand, it may provide consistency and structure, but on the other hand, some consider it too heavy and abstract. The newly described content of Insurance's strategy highlights customer focus. According to it, Insurance wants to provide sustainable solutions for its customers to improve their wellbeing. Here, as well as in the case of Industrial, the company wants to transform itself into a solutions provider, instead of being a mere product-oriented company.

The main artifact of Insurance's strategy is a PowerPoint document that describes the company's vision, strategic intent and values. This document was written on purpose in an elevated and abstract style to evoke strategic thinking at the lower levels of the company and to encourage them to surpass themselves. Many managers of Insurance feel that they can identify themselves with Insurance's strategy, since they believe that it genuinely aims at improving customers' life. However, critics say that the strategy is too abstract and grandiose and that it can mean almost anything.

Due to the participatory culture, employees of Insurance are often invited to participate and influence the strategy work in different phases of the strategy process. Strategy communication is also regarded as a crucial element of the strategy implementation at Insurance. The organization has, for instance, arranged company-wide strategy seminars for the whole personnel at the ice hockey arenas and fair centers, wherein the strategy has been launched and illustrated. Insurance has a wide intranet that is used for many purposes, including strategy communication. For instance, during the 
last strategy period, the strategy was illustrated by cartoon figures, which were widely used as symbols of the new strategy and they were placed all over the intranet. Even the PC screensavers were programmed to show them. The company also provides employees with various strategy booklets, where the strategy is discussed and illustrated.

Although at first glance Insurance seems to be a remarkably happy organization in terms of its organizational culture and way of operating, there are some contradictions and disagreements under its calm surface. Like at Industrial and Polytechnic, there seem to be differences at Insurance between the "center" and "periphery", here the headquarters and customer service unit. The headquarters of Insurance is rather large and thus it also has a great influence on Insurance's culture and operations. At the headquarters, many people are proud of being "Insurance people" and consider themselves to be at the core of the organization. The customer service unit, on the other hand, being fragmented and spread across the business area, is more loosely coupled to the center and thus operates more independently. The people who work for the sales organization are more critical towards the headquarters and its ideals than the people who work at the headquarters.

\subsection{STRATEGY (RE)PRODUCTION}

At Insurance, the (re)production of strategy follows rather closely the same lines as in the case of Industrial and Polytechnic. Here, strategy is described as a direction or means that shows the way toward the desired destination or vision. At Insurance, strategy is also given a strong pragmatic emphasis by highlighting that it should be a concrete part of everyday work activities at Insurance.

\subsubsection{DIRECTION AND CONDITIONS}

Firstly, Insurance's strategy is (re)produced as a direction and conditions that guide the actions of Insurance. In the following, a manager from Insurance describes his/her view of strategy by using an illustrative example: 
"It [strategy] is a pipeline in the direction we want to move in, and what actions are wanted. [...] I've heard a terrific example [...] of how a sort of flight of migratory-birds flies. Well, there are two guidelines. Take the direction from the sun, and don't collide with others. That illustrates strategy quite well. The strategy is not for telling that now it's time to flap your wings, flap the wing up, and flap the wing down. But strategy is about telling that this is the direction and then the conditions that keep you from colliding with a friend."

At the beginning of the comment, the mechanistic discourse rears its head. Accordingly, strategy is a "pipeline" for the desired destination and direction. After that, the manager shares an example that compares strategy to the "flight of migratory-birds," which contains two "guidelines:" head for the "sun" and do not "collide with a friend." In line with this, the manager considers strategy as a something that gives the company and people, the "birds," a general direction, instead of detailed advice on how to act in certain situations. Strategy is a rather loose framework that includes some conditions, but that allows individuals to act and behave in their own ways - as long as they remain in the "pipeline." The following comments from two other managers confirm this idea:

"Strategy is choices of what we do, where are we heading, and how do we get there."

"In strategy, you think further, that where are we heading and what actions are done."

It is interesting that the previous comments from two different managers are almost exactly the same. Strategy is something that defines both the direction of the company and the means to get there. It answers the questions "where we are heading" and "how do we get there." This kind of rhetoric is also a manifestation of the pragmatic macro-discourse, which highlights concreteness and clearness in strategy work. Here, strategy is something that guides the everyday actions of the organization by providing it with a direction and means to get there. There is also some sort of a reference to the spiritual macro-discourse, which discusses the journey to the chosen vision. 


\subsubsection{CONCRETE PART OF EVERYDAY LIFE}

While the previous way of (re)producing strategy treated strategy as a rather loose vision that provides liberties to the people who follow it, here strategy gets a more pragmatic emphasis. This is an example of how the pragmatic discourse that is very dominant in the (re)production of strategy, is used at Insurance. In the following quotes, the pragmatic discourse is rather obvious:

"That would try to bring it [strategy] to everyday action, to everyday life in some way. But it should be a natural way. That it should not be an unnatural way."

"That it [strategy] would be taken to the most concrete level possible, so that the individual seller understands what this means 'in my life. 'That it wouldn't remain somebody else's thing. This is everyone's thing, and this brings benefits for the customers, for us, as well as for the company."

"There [in strategy] are still such fancy words, that what is the message to your own unit. That what would it mean in practice, in your own work? That it won't be experienced as some separate thing, some [of the] things made up by the bosses."

The first comment is a call to take the strategy to the everyday life of the people. Here, strategy is clearly considered something that belongs to everyone in the organization. As can be seen, the strategy (re)production by drawing on the pragmatic macro-discourse can be quite normative, even demanding by nature. According to the comments, "everyone" should understand what strategy means in their "life;" it sounds almost like strategy is something more than just a management discipline. This could also be interpreted as a reference to the spiritual macro-discourse. The second comment emphasizes the importance of concreteness in strategy work. Even "an individual seller" should be able to understand what strategy means in his/her life. Strategy should also belong to everyone, it is "everyone's thing," like the manager concludes. Again, strategy should not be a separate "thing" or "things made up by the bosses," referring to the top management of Insurance, but a part of the "everyday action" of individuals. The third comment grasps the abstract and general language of Insurance's strategy. The manager acknowledges that there are "fancy words" in the 
strategy documents and insists that these words be concretized when taken to different units and their people.

As can be seen, there is a certain contradiction present in Insurance's strategy (re)production. On the one hand, there are comments that construct strategy as a general guideline that does not even aim at providing practical and everyday advice on how to operate, and on the other hand, there is evidence that the strong pragmatic discourse insist on a pragmatic approach to strategy. This is by no means an accident considering the abstract nature of Insurance's strategy.

Now strategy has been (re)produced by the managers of Insurance. Based on it, we know how strategy is considered by them at a general level. Next, the other element of the strategy consumption process, strategy usage, is discussed.

\subsection{USAGE: INSTRUMENTAL TACTIC}

It seems that at Insurance strategy is applied instrumentally mainly for three purposes. Firstly, managers carry out strategy as company's intent that they concretize and sell to their subordinates. This activity is considered to be a part of their duty and job as managers, which at the end of the day also benefits them. Here strategy is used as a deliverable of company's intent. Secondly, strategy appears to managers as a source of meaningfulness and purpose, which they take forward to their subordinates. Strategy is employed as a means to make subordinates' everyday work meaningful and purposeful. And thirdly, managers take strategy as a device to build and establish legitimacy for the decisions and choices that have been made.

\subsection{1 "INTENT THAT IS CONCRETIZED AND SOLD"}

The first element of the instrumental strategy consumption at Insurance is an example of a rather non-personal strategy usage. Here, strategy is treated as an embodiment of Insurance's intent, which managers execute. It seems that Insurance's intent is almost incarnated in the strategy, and managers apply this instrument to carry the intent further. Strategy is a managerial deliverable that managers take further, which they consider to be their basic job. Managers are almost like waiters and waitresses of the 
strategy serving it to their subordinates. The following examples outline how ownership of the strategy belongs to the management of Insurance. Strategy is mostly their intent and the managers sell this intent forward.

"But it [strategy] is the company way to take things further into some direction. [...] When it's top-down, the strategy [is] done up there and then we act so that things would get realized. In other words, [strategy is] management's clear intent and we execute it. That's our purpose."

"The company has some policy that is being sold [...]. My job is based on that."

"Of course, the strategic choices are made at the house level. And then they are considered very carefully right at the team level, that what does this mean for our work and how do we notice it."

In the previous comments, the strategy is clearly regarded as something that belongs to the company, the "house." Strategy is "the company way, policy, or vision" or "management's clear intent." It is as if the managers wash their hands of the content of the strategy and put their effort solely into its execution. This is no surprise, since strategies are made "up there," and then executed by the middle managers and their teams. The managers' job is to "sell" the strategic intent of the company to their subordinates. The emphasis in this talk is put on the execution of the strategy in a clear and concrete way, which suggests the pragmatic macro-discourse. Also, the mechanism could be spotted from here, as the managers talk about a rather straightforward execution of the strategy. They almost seem to consider themselves part of a strategy machine.

The term "intent," which is used here, stems from the strategy documents of Insurance. The most crucial strategy document of Insurance describes the strategic intent of the company at a rather general and abstract level, and it is this intent that the managers are selling here. Obviously, the managers conclude that this intent belongs to the "management," not to them, which is interesting to note. 


\subsection{2 "THE BRINGER OF MEANINGFULNESS"}

The second element of Insurance's strategy usage considers strategy as a source of meaningfulness and purpose that managers use to justify their everyday work both to themselves and to their subordinates. Here strategy is a framework or outline that provides a reason for the work activities of Insurance. The following quotes show how this kind of an instrumental use is constructed by the managers:

"Why we do like this, what does that mean now, and what for [...]. Whenever it's possible, you reflect it to strategy. So, although we talk about an individual change, it has always a greater meaning. Like why is this done right now."

"Well, I think [that] everything needs to have a purpose and reason and explanation for why we do it, what we do, and where we are heading. [...] This [strategy] gives a sort of framework for everything. It clarifies. If we didn't have a clue, we would be quite lost."

In the first quote, the manager brings out how he/she uses strategy as a mirror to " $r e$ flect" things, such as changes, to it. Even "an individual change" needs to have " $a$ greater meaning," as he/she puts it. For him/her, strategy seems to explain and justify why something has to be done "right now," and this brings "meaning" and purpose for him/her. The second comment follows the previous thought. The manager outlines how strategy provides a framework for everything, including what is being done and why, and where the organization is heading. Here, strategy is used as a "reason" and "explanation" for why things are done in a certain manner. Strategy provides a clue for the work activities of the organization, and without it "we would be lost," the manager concludes. Here, the manager uses strategy as an instrument to increase the meaningfulness felt by the subordinates.

This kind of strategy use stems from both the humanistic and spiritual macrodiscourses. On one hand, the comments could be interpreted as humanistic statements emphasizing the meaningfulness felt by an individual in the strategy process. On the other hand, this kind of talk could also be read as a call for a deeper purpose and meaningfulness, almost like the meaning of one's life, which stems from the spiritual macro-discourse. 


\subsection{3 "JUSTIFICATION FOR THE DECISIONS AND CHOICES"}

In the following, the instrumental strategy use gets a pragmatic emphasis as the managers use it as a justification for the choices and decisions that have been made. Here, the managers use Insurance's strategy as a means to justify and legitimize the choices and decisions that have been made. In a way, strategy is used as a back-up to cover and secure managers' actions. Here, a manager describes how he/she uses strategy in his/her work to justify decisions and choices:

"Especially, if an employee criticizes why something has to be done, 'this kind of strange thing', I'll bring out the strategy angle or say that this is related to this part of the strategy [...]. I'll base it on the strategy [...]. That you have a justification for why you bring up some matter. That you can justify it and stand behind it. Probably team members will get a feeling that this was an important thing now, when there was such justification. For me, it [strategy] is justifications and support for the things that I take further."

"If we think about practical examples, how we deal with something. If I need to tell a bigger crowd about some decision, for instance with e-mail, I say that this is the way we operate [...] that why we operate like this now [...] and those things involved in our strategy are also included."

The manager uses strategy as the instrument to justify and legitimize the message he/she delivers to his/her subordinates. When the subordinates "criticize" something that needs to be done in face-to face interaction, strategy provides a "justification" or "base" for him/her to deal with such resistance. On his/her words, he/she brings "the strategy angle" and relates the decision to Insurance's strategy. Also, when the manager needs to "tell a bigger crowd about some decision" with e-mail, he/she "includes things involved" in the strategy in his/her message.

Here strategy also allows the manager to stand behind the decisions him/herself. $\mathrm{He} / \mathrm{she}$ seem to use strategy as a "support" for him/her. Strategy is also regarded as something that is "important." The manager brings out how his/her subordinates will regard something as an important issue when he/she justifies it with the strategy. It seems that the manager uses strategy like this more or less on a daily basis. With this 
kind of a usage tactic, the strategy appears as an everyday justification for the decisions and choices.

\subsection{Usage: Playful tactic}

The playful strategy usage at Insurance is by nature very critical. The playful critique is used for three different purposes. Firstly, the abstract content of Insurance's strategy is joked about. Secondly, Insurance's top management's and headquarters' roles and abilities are questioned with a satiric and ironic rhetoric. And thirdly, the methods used as the symbols and tools in Insurance's strategy communication are criticized.

\subsection{1 "BIBLICAL COMMANDMENT AND THE CATECHISM"}

As mentioned, Insurance's strategic intent is formulated on purpose in a rather abstract and general way to encourage people to surpass themselves. Or, this is at least what the top management hopes for. However, the content of strategy and abstractness of strategy arouses a lot of astonishment and criticism among the middle managers of Insurance. In the following extract from an interview, a manager of Insurance outlines how the company's strategy is by nature abstract and complex:

"In my opinion, the great process has been over-emphasized at Insurance. It produces good looking PowerPoints, but if you ask what this means in people's everyday life, those strategy writers can't give you an answer. This is said quite harshly, but I think there's no use in giving you answers related to our religion [...]. If it's so that there's strategy, and then there's strategy communication as a separate thing, it raises the question of whether the strategy is so difficult and complicated that you have to create a separate process for explaining it. [...] It [communication] should be baked into the strategy so that we don't have a catechism, that here's the biblical commandment and then what does it mean, a very long explanation. [...] You somehow get the feeling that you say things elegantly so the managers understand it, and then you tell a different story so the common people will understand."

The previous comment obviously has a spiritual underpinning in it. The corporate culture of Insurance is called “our religion," hinting that at Insurance people tend to give 
certain answers that are in line with the company ethos or belief system. In this case, the manager clearly rebels against this code of conduct and reveals some "harsh" facts that he/she has to know. But what is included in Insurance's religion? Maybe the "over-emphasized" strategy process that produces beautifully made PowerPoint slides that do not have much to do with the "everyday life" of Insurance's people. The central figures in this process are the "strategy writers," who do not seem to know what they have written even themselves. The spiritual macro-discourse is also present when the manager compares Insurance's strategy to a "biblical commandment" and the strategy communication to the "catechism" that explains the spirit and letter of the commands. However, the manager does not regard this as a good thing, since it sort of separates "the managers" capable of understanding the "elegant" strategy from the "common people," who hear "a different story."

Here the same manager also outlines how the company values are by nature very ambiguous:

"For instance, these values that the company has, there's a sort of amusement, that everyone interprets them as they want. Entrepreneurship, which is our value, if we try to tell the Insurance people what the entrepreneurship means for your and for your work [...]. For some it's some damned kind of trading, for some it's risk taking, for some it means that you can try whatever you want. Very different things."

The manager finds Insurance's values, which are considered to be at the core of its strategy by many, "amusing," since they can be interpreted so differently by the people. The humanistic macro-discourse is used here as a resource to illustrate that the meaning of values is constructed individually. The value of "entrepreneurship," for instance, can be taken in many ways according to the manager. This kind of a strategy use suggests that Insurance's strategy work is some sort of nonsense that does not have a close relation to the everyday activities of the organization. The company values are vague rhetoric, and the strategies wordmongering. The manager him/herself somehow zigzags in the midst of all this. It is almost as if he/she is throwing up his/her hands in the air and saying that there is nothing he/she can do anymore. And clearly, he/she does not feel much ownership for strategy of this kind. 


\subsection{2 “OH NO, DID I PUSH THE WRONG BUTTON?”}

Although the strategy work at Insurance seems to be rather open by nature, and the people who are willing may take part in it, it seems to be still personified in the top management of the company. Their role as strategist is, however, anything but unquestioned. In the following, a manager gives a satirical example of how the top management of Insurance communicates strategy to others and what the manager himself thinks of it:

\footnotetext{
"When the top management is presenting these [strategies], they are very bound to the [PowerPoint] slides. They don't dare to take any of their own space there. [...] They proceed according to these slides and they are nervous whether 'I pushed the right button so that the following sliding text would certainly come next'. Or 'Did I push [it] too many times, since the sort of text appeared and the arrow points into that direction?' Well, that shows that it's not their own thing that they're talking about there."
}

The previous comment does not give a particularly good picture of Insurance's top management. On the contrary, it actually suggests that they are like marionettes performing strategy rituals. In this example, the top managers seem to be more interested in knowing whether they are able to use PowerPoint in the right way, than the content of the strategy. The managers do not "dare to take any of their own space there," concludes the manager. He also makes a guess that the strategy is not "their matter." This is an interesting mention, since one would easily think that the strategy is in the top management's possession. But in this case, it seems that it is neither the speaker himself nor the top management of Insurance who own it. Instead, it is some third source that has ownership, and the top management is just repeating it mechanically. In the following, the same manager sheds more light on this by drawing on the spiritual macro-discourse:

"But when you read bullet points from the paper, it says that you are witnessing some article of faith and you are afraid to use the wrong words."

The top managers of Insurance seem to be "witnessing some article of faith." This is clearly spiritual rhetoric comparing strategy to religious belief. The manager consumes the spiritual macro-discourse in an ironic manner to outline how corny and ri- 
diculous the top management appears to him/her with regard to the strategy. When the strategy is communicated in this way, it is something that is not worth taking seriously. It is like a serious joke, a comic play presented by the top management that the employees are invited to watch from time to time. However, this play is not about improvisation. It seems that there is a certain script to follow, even the top managers are "afraid to use the wrong words" with regard to strategy.

\subsection{3 “COME ALONG, GHOST!"}

The playful strategy usage brings out the differences and contradictions that exist between different parts of Insurance. In the following comments, a contradiction is constructed between the headquarters and sales organization of Insurance:

"When we sit at some meeting, where me and my colleagues are talking about these things [strategy], and when the company tells us that 'This is the way we want to operate' somebody asks 'How do you intend to do it in our area?.' 'Come along and show us the model there!'."

"When I compose different kinds of presentations, I generally even outline it on purpose. When I picture headquarters, I usually draw a ghost there. I really drive them [headquarters and sales organization] apart from each other, but its purpose is just to entertain."

This is interesting and playful talk from the manager of Insurance's sales organization. The talk is in contrast to the common view that Insurance is a consensus driven organization, first and foremost. The previous comments create a clear tension between the headquarters and a sales organization at Insurance. In the first quote, the manager illustrates how he/she and his/her colleagues tend to question the strategic direction received from the headquarters, referred as the "company." It seems that the manager considers the 'company people' as sort of strategy theorists, who are eager to present their ideas and "models," but who leave the practical realization to the sales people, which is the most difficult part of the plan. Thus, the sales managers say to the "company" managers: "Come along and show" how this works in our area! This is an indication of the pragmatic macro-discourse. 
The second comment outlines how the sales manager maintains and creates the tension between the headquarters and sales organization on purpose. In his/her own presentations, he/she pictures the headquarters as a "ghost." In this way he/she "drives them apart from each other." And he/she does it just for the purpose of "entertainment." This is playful strategy consumption, indeed, with the aim of picturing Insurance's strategy as headquarters" "model" that does not have too much to do with the everyday work of the sales people. The only ones who take strategy seriously are the representatives from the headquarters. This could be read as a way of showing silent and cynical resistance towards the strategy and Insurance's headquarters.

\subsection{4 “MAO’s LITTLE RED BOOK”}

As mentioned earlier, Insurance has put a lot of effort into producing the strategy communication material and tools for promoting strategy and to make it an everyday matter in the organization. There are managers who consider this "brainwashing material" something useful when adopting the strategy, but to some it appears more like propaganda. Here, a manager plays with this issue interestingly:

"When the new employees arrive and when the new strategy period begins, a sort of strategy booklet is delivered to every employee [of Insurance]. It was like Mao's Red Book.”

Here, the manager compares the strategy communication material that Insurance provides for its employees with Mao Zedong's Little Red Book. The book published by the People's Republic of China in the 1960s contained Chairman Mao's quotations and ideas with the purpose of transforming Chinese society. Every Chinese was to own and carry this iconic book. During the Cultural Revolution it was standard practice to study and read the book at all work units in China during working hours. It was argued that Mao's thesis would bring enlightenment to work.

Comparing strategy to Mao's book is a quite clever discursive move from the manager. In a way, the red book was also a 'strategic' tool to change the Chinese people and society just like Insurance's strategy is an attempt to change Insurance's people and working culture. By distributing "the strategy booklet" to every employee of Insurance and requiring people to read it, the management of Insurance engages in the 
same kind of a practice as the Chinese government. By comparing Insurance's strategy booklet to the Little Red Book of Mao, the manager also hints that Insurance's strategy has an ideological slant like the Chinese Cultural Revolution did.

The purpose of this kind of playful strategy use is obviously to ridicule and criticize Insurance's top management and strategy. Here, the manager uses strategy to entertain him/herself although he/she is unable to escape or resist it totally. This kind of strategy use does not produce any concrete outcomes for the manager, but establishes and maintains his/her identity as a sort of guerilla manager, who dares to resist the strategy.

\subsection{USAGE: INTIMATE TACTIC}

The intimate strategy usage at Insurance has three elements. Firstly, managers use strategy to describe their commitment and devotion to Insurance's strategy. Here managers' existence is tied closely to the strategy, almost as if they would sacrifice themselves for it. Secondly, managers use strategy to outline their helplessness and incapability in front of it. This can be read as a sign of vulnerability and fragility in their existence with regard to strategy. And thirdly, managers use this tactic to disindentify themselves from the strategy by revealing how they secretly silence it and ignore some institutionalized and compulsory practices of it. Here strategy is used as a counterpoint of their identity; strategy is anything but their thing.

\subsection{1 "WE BRAINWASH OURSELVES"}

Many managers of Insurance outline how they have to understand company's strategy before they are able to communicate it further to their own subordinates and act as proper supervisors. Also, many managers genuinely believe in Insurance's strategy since they think that it benefits their customers and helps their lives. Hence, they commit themselves to the strategy. Here a manager explains what this means in his/her case:

"Well, I think that my role is, firstly, to buy the story [strategy] and perceive my own role as a realizer of the strategy. [...] We got a strategy workbook and those 
playing cards and [...] all these screensavers that some call brainwashing material. [...] But I consider these good for adopting the thing [strategy]. [...] It [strategy] is sort of brainwashed to your subconscious. [...] The whole system of ours has swallowed the hook [strategy] pretty well."

In the previous comment the manager uses strategy with the intimate manner by concluding that he/she has to "buy" the strategy and perceive his/her "own role" in it. $\mathrm{He} / \mathrm{she}$ consider his/her role to be that of "realizer," which refers to the pragmatic macro-discourse. The manager also tells how some call the material created for ensuring the strategy communication as a "brainwashing material" but how he/she considers it good and fitting for him/her to adopt the strategy. It is interesting how he/she also states that the strategy has been "brainwashed to your subconscious," and how the organization has "swallowed the hook" of the strategy effectively. This sounds violent, almost like the managers have been somehow indoctrinated with the strategy.

Here another manager continues how he/she takes Insurance's strategy:

"I feel that during the every three year time span [a strategy period at Insurance] we brainwash ourselves to believe strongly that this is a good strategy. That it's easy to speak of it from the bottom of your heart."

The manager uses the same term, "brainwashing," to describe the process how strategy is adopted him/her. Unlike in the case of the first manager, this manager brainwashes him/herself to believe in the strategy and its goodness. This process appears to be collective since the manager says that "we" brainwash "ourselves" to believe in the strategy. Again, this sounds like the manager is not sure about the quality of the strategy, but that he/she would make him/herself to "believe” in it. If he/she would not believe in it, he/she could not speak of it wholeheartedly. Here the spiritual macro-discourse is used rather obviously. The strategy is clearly constructed as a spiritual phenomenon that requires faith and followers. The manager is in the position of spreading the strategy gospel further, which is why he/she needs to have a personal relationship with it.

Here, the managers devote and commit themselves to the strategy. They take it to their "heart" and even to the "subconscious" to be able to act according to it. The strategy appears to be a sort of transcendental phenomenon, which makes them to 
submit themselves to it. They voluntarily relinquish their own will to the strategy and let the strategy guide them. It seems that they either genuinely believe in the goodness of the strategy, or either fear not to act according to it.

\subsection{2 "FAITH IN STRATEGY"}

Here, a manager again devotes him/herself to strategy. The spiritual macro-discourse constructs strategy as a matter of faith, outlining the personal belief in it. The following extract is an example of the intimate usage of strategy in this respect. In it, the manager constructs strategy almost as a spiritual experience for him/her while discussing his/her relationship to strategy:

"Well, from my opinion it requires that you have faith in the strategy, then everything else comes with it. [...] But if you don't believe in it, you won't get people excited. The one who talks [about strategy] has to be an Insurance people. [...] I got the faith, and I believe that the majority of our management team got it, we've come here straight from the school and we've been brainwashed with it. We've had a very good supervisor, who has brought us up to be the Insurance people. [...] But not everyone has that faith."

The beginning of the quotation reveals the spiritual underpinning of this comment. The manager regards faith as a crucial antecedent of strategy communication. When you "believe" in strategy, "everything comes with it." But if you do not believe in it, you do not "get people excited" about it. Also, in order to speak about the strategy, you need to be an "Insurance people." But how has he/she got the faith in Insurance's strategy? He/she has joined the company right after the school and been "brainwashed" to believe in the strategy. A central actor in this brainwashing process has been his/her previous supervisor. The supervisor is produced as a charismatic and powerful, almost like a godly figure that has "brought up" the manager and his/her colleagues as true believers of Insurance and its strategy. Despite his/her own faith, the manager, however, doubts that not all "have faith" in Insurance. This hints that the true faith in Insurance's strategy is only possessed by a few of the faithful such as him/herself.

This is a lively example of the intimate usage tactic. Here, strategy is not an instrument that is used as a managerial tool, but obviously a spiritual experience that is by 
nature very personal. This is the kind of talk that reveals a manager's own personal, intimate feelings towards strategy. Strategy gets under his/her skin. It may be no surprise that this kind of the intimate tactic is used in Insurance, as the company is known for its long-term careers and loyal employees. As the managers put it, they have grown up to be "the Insurance people." The manager constructs him/herself definitely as a part of a family or community, which he/she has been brought up to. $\mathrm{He} /$ she belongs to the company.

\subsection{3 "I HAVE NO IDEA"}

Previously, the intimate strategy usage treated the strategy as something that the managers have to adopt themselves. It was referred as the "brainwashing" and "swallowing the hook." Now, the intimate strategy usage reveals that the content of Insurance's strategy is so general, difficult and abstract that the managers find it hard to understand and communicate further. Thus, they feel themselves helpless in front of it. In the following, a manager tells how he/she feels him/herself insecure and hesitant about the strategy in some occasions:

\footnotetext{
"And when you communicate it [strategy], people wait for something concrete right at the beginning. [...] That how it is realized and how it really differentiates us from our competitors. [...] Sometimes you'd want to say that actually I don't know. That, this is a quite sticky position."

"When I've communicated [strategy] at our advisory board meetings [...] There was a discussion that all the insurance companies are doing the exactly same, that what makes the difference. [...] It made me feel uncertain that what do I answer to that."
}

The manager has been in the situations where he/she has been asked to concretize and crystallize Insurance's strategy. He/she had found it difficult, admitting that he/she did not know the answer. It made him/her feel "uncertain." The manager understands that this is a "sticky position," since the employees would like to know how the strategy will be "realized" and how it "differentiates" Insurance from its competitors. According to the manager, Insurance's strategy does not answer these questions, or at least he/she has not found the answer in it. 
In the following, a manager describes how Insurance's strategy is constructed through two languages in the organization:

"We sort of speak at two levels. We have an official strategy language, which is difficult to understand, pretty PowerPoints. And then the [...] everyday life [...], where you try to cope with the strains, those objectives that are given, and that you try to fulfill. [...] I think that quite many of us managers in the field build their own stories, which are hopefully based on the strategy. But maybe sometimes you feel a bit homespun, that how do I understand these strategies."

Here, the distinction is produced between the strategy and "the everyday life." The "official strategy language," as the manager described it, is documented in the form of the PowerPoint slides and is "difficult to understand." On the contrary, everyday life is full of strains and challenges that you cope with. The manager positions him/herself as one of the "field managers," who tell their "own stories" based "hopefully" on Insurance's strategy. The manager feels him/herself "homespun," somehow as an outsider compared with the world of strategy that he/she is obligated to communicate. He/she follows his/her own paths and hopes that the story he/she has "built" is legitimized in the wider organizational context. The pragmatic macro-discourse can be sensed here. The manager is clearly more sympathetic to the everyday life of people than the difficult PowerPoint presentations discussing Insurance's strategy. He/she is saying that Insurance's strategy does not reach the employee level of the company. $\mathrm{He} / \mathrm{she}$ also admits that the strategy is unclear to him/her as well, which makes him/her feel insecure and helpless.

\subsection{4 "I'M NOT MOTIVATED BY IT"}

While in the previous streams the intimate strategy usage had a seemingly positive attitude towards Insurance's strategy, in the following the strategy is resisted. Here, a manager talks about how he/she takes strategy and his/her own role in it:

“I have this professional job here at the background, so I haven't had any meetings where I would have talked about the strategy to my subordinates, and I won't be very happy to do it. [...] I don't consider it an appropriate task for me. I rather talk about math, not about the strategy." 
"I haven't gone through it [strategy]. And I'm not that deeply motivated about it that I would go through it. These professional tasks appeal me more. That I want to go through them, not the strategy, necessarily."

"I'd probably go against it and I'd think that I'm not a right person [...] And I do think that it's perhaps a quite prevailing phenomenon here at Insurance, and probably elsewhere as well, that there aren't many eager Messiahs here, who want and [who] are eager to talk about the strategy."

The manager clearly dis-identifies him/herself from the strategy of Insurance. Although the top management of Insurance, at least implicitly, expects that the other managers will communicate the strategy to their own subordinates, here the manager rejects doing it on purpose. The manager regards the role of strategy communicator as "messianic," referring to the spiritual macro-discourse. The manager says that he rather talks "about math" than the strategy, since he/she does not concern the strategy communication as "an appropriate task" for him/her. The manager also says that he/she has not gone "through" the strategy and neither will he/she do it, since the strategy does not motivate him/her. It is the "professional tasks" that appear as more appealing to him/her. So, in other words he/she indentifies him/herself more with his/her profession than the strategy as a managerial device.

In the following, another manager discusses about how he/she considers a practice related to the strategy implementation at Insurance:

“Well, I take the score card [...] That's one thing that I should have done. I think that I haven't done it even once during this three year time period although it should have been done always. [...] But it is not something that would influence my working anyway. [...] I'd probably get fired if someone heard about this [laughs]."

The manager reveals how he/she has not filled "the score card" (referring to the Balanced Score Card of Insurance) even once during the last three years, although he/she should have done it. The manager considers the score card as something that does not influence his/her working a lot. However, he/she is aware that ignoring this practice so intentionally may cause him/her some harm. "I'd probably get fired if someone heard about this, " he/she says and laughs. 
Here the managers dis-identify themselves from the strategy by silencing it and ignoring some practices related to it. They do not consider strategy meaningful or important for themselves in any way. They position themselves in opposite to the strategy. This kind of intimate strategy usage reveals how strategy is resisted and silenced quietly and tacitly in the organizational life. It questions and challenges the ideals (re)produced previously that emphasized how strategy should belong to everyone in the organization by ignoring strategy on purpose.

This chapter has discussed how the managers of Insurance have (re)produced and used strategy. The strategy (re)production and usage and the macro-discourses related to them are summarized in Table 11.

\section{TABLE 11 STRATEGY CONSUMPTION AT INSURANCE}

\section{N S U R A N C E}

\section{(RE)Production Usage}

Strategy describes the vision or intent Insurance aims at. (Spir)

Strategy sets conditions on how the company proceeds to the vision. (Mec \& Spir)

Strategy should be a coherent part of everyday life at Insurance. (Prag)
Instrumental:

Managers use Insurance's strategy as an intent that they concretize and execute as a part of their job as managers. (Prag \& Mec)

Managers use Insurance's strategy as a tool to motivate and inspire their subordinates. (Hum \& Spir)

Managers use Insurance's strategy as a means to justify and legitimize choices and decisions. (Prag)

Playful:

Managers amuse themselves by joking about the abstract content of Insurance's strategy. (Spir)

Managers ridicule the role of Insurance's top management and headquarters in strategy. (Prag \& Spir)

Managers parody the methods used as symbols and tools in Insurance's strategy communication. (Spir)

Intimate:

Managers devote and submit themselves to Insurance's strategy. (Spir \& Mil)

Managers feel themselves helpless and incapable in front of Insurance's strategy. (Prag)

Managers dis-identify themselves from Insurance's strategy by silencing it and ignoring some of its practices. (Prag) 


\section{DISCUSSION}

This chapter discusses the key findings of this work and evaluates their theoretical relevance. I seek to make a twofold contribution to the existing literature. Firstly, I will discuss the results from the perspective of the practice approach to strategy by showing how strategy consumption integrates the macro and micro-levels of strategy practice. Secondly, I will reflect on the results from the perspective of the discursive strategy view by discussing and illustrating the discursive nature of strategy consumption.

\subsection{STRATEGY CONSUMPTION: CONNECTING MICRO TO MACRO}

The practice approach to strategy seeks to understand how strategy is practiced in organizations. More precisely, it has urged us to study the practice of strategy both at intra and extra-organizational levels (Whittington 2006). In other words, it has called for research that would uncover the relation between the institutionalized, socially defined modes of doing strategy, and the actions of strategy practitioners in organizations that are influenced by these socially accepted codes (Jarzabkowski et al. 2007).

In this work, my intent has been to bridge this gap by studying the use of strategy. I have applied the thinking of de Certeau (1988) to show how strategy, as an institutionalized management discipline, is practiced, that is consumed, by the managers in three case organizations. As a result, I have shown how the two context-specific and embedded discursive practices of strategy consumption, the (re)production and usage, are closely connected to the macro-level strategy discourses present in the wider strategy and management literature (for a summary, see Tables 12 and 13). By showing 
this interconnection, I have demonstrated how managers, as strategy practitioners, consume and use different macro discourses of strategy. I have also shown what elements ((re)production and usage) and styles (instrumental, playful and intimate tactics) compose a strategy consumption trajectory.

Although de Certeau's ideas are familiar within the practice-oriented research community, there are not too many empirical works that would have applied his ideas to explain how strategy is practiced (cf. De La Ville \& Mounoud 2003). The findings of this work contribute to the practice approach to strategy not only by integrating the gap between the extra and intra-organizational approaches to strategy practice, but also by deepening our understanding of how strategy is practiced in organizations. They show that strategy may be consumed and used by managers in more creative and improvisatory ways than the previous, namely rational-oriented, strategy research has shown.

TABLE 12 STRATEGY (RE)PRODUCTION AT CASE ORGANIZATIONS

\begin{tabular}{|c|c|c|c|}
\hline $\begin{array}{r}\text { DISCURSIVE } \\
\text { PRACTICE }\end{array}$ & INDUSTRIAL & Polytechnic & INSURANCE \\
\hline (RE)PRODUCTION & $\begin{array}{l}\text { Strategy is a way or means } \\
\text { to reach the vision or to win } \\
\text { the war. (Spir \& Mil) } \\
\text { Strategy is created and exe- } \\
\text { cuted through the systematic } \\
\text { strategy process (Mec) } \\
\text { Strategy concerns the entire } \\
\text { personnel. (Hum \& Prag) }\end{array}$ & $\begin{array}{l}\text { Strategy means realizing the } \\
\text { inspired vision. Strategy is } \\
\text { ladders or road signs that } \\
\text { lead to the vision. (Spir \& } \\
\text { Mec) } \\
\text { Strategy, as an agreed con- } \\
\text { tract, requires participation } \\
\text { and involvement of the en- } \\
\text { tire personnel. (Hum) } \\
\text { Strategy is pragmatic and } \\
\text { that should be taken to the } \\
\text { grass roots, where everyday } \\
\text { decisions are being made. } \\
\text { (Prag) }\end{array}$ & $\begin{array}{l}\text { Strategy describes the vision } \\
\text { or intent Insurance aims at. } \\
\text { (Spir) } \\
\text { Strategy sets conditions on } \\
\text { how the company proceeds } \\
\text { to the vision. (Mec \& Spir) } \\
\text { Strategy should be a coher- } \\
\text { ent part of everyday life at } \\
\text { Insurance. (Prag) }\end{array}$ \\
\hline
\end{tabular}

Jarzabkowski (2004) introduced the concept of "management practices-in-use" to explain and describe how institutionalized practices, such as strategy, can be used in ways that may not comply with the original purpose of practice. The strategy usage illustrated in this work sheds light on the use of strategy practices by pointing out how strategy is practiced by managers with improvisatory and adaptive manners for their contextual and situational needs. For instance, when using strategy instrumentally, managers analyze their business environment, set targets and objectives (Industrial), 
and try to position their organization into the market (Polytechnic). Here their strategy usage reminds the rational strategy approach in various ways (cf. Chandler 1962). However, in other parts, mangers seem to use strategy instrumentally for totally different purposes than the rational ethos would have suggested. For instance, the legitimization aspect (Knights \& Morgan 1991) seems to be acute in every case organization, as strategy provides the managers with the means to secure their back and legitimize their work. At Polytechnic and Insurance, managers apply strategy instrumentally to motivate their subordinates. Strategy seems to offer them a device that connects their work with that of their subordinates to the objectives and higher level purposes of their organization.

Although strategy is acknowledged ((re)produced) as a management discipline rather unanimously in different case organizations, the way it is used by the managers in their everyday life is very context-specific and largely based on their individual needs. This finding shows that strategy is an indefinite and versatile (and maybe even precarious) practice for managers, and that they use and "poach" this practice in multiple ways and with multiple means that may even depart from the ideals that they themselves attach to it. (Whittington 2003.) Different kinds of ideals and models (macrodiscourses) can be used creatively by managers, depending on their prevailing situation and needs. For instance, at Industrial strategy is treated as a loose framework that allows managers to maneuver with their own sub strategies (cf. Laine \& Vaara 2007). At Polytechnic, managers perform some semi-illegal actions and tricks in order to cope with strategy in their everyday work. They also use strategy to solve major problems in their units by labeling them strategic. These findings show how strategic actions of managers may not arise from the intended and intentional strategies, as the purely rational thought would suggest, but on the contrary, they emerge through the everyday "practical coping" and "dwelling" of the managers when things are labeled and regarded as strategic (Chia \& Holt 2006, 2009). This is also in line with the ideas of the processual strategy approach (cf. Mintzberg \& Waters 1985). 
TABLE 13 STRATEGY USAGE IN CASE ORGANIZATIONS

\begin{tabular}{|c|c|c|c|}
\hline $\begin{array}{r}\text { DISCURSIVE } \\
\text { PRACTICE }\end{array}$ & INDUSTRIAL & PolyteChNiC & INSURANCE \\
\hline $\begin{array}{r}\text { USAGE: } \\
\text { INSTRUMENTAL } \\
\text { TACTIC }\end{array}$ & $\begin{array}{l}\text { Managers use strategy to } \\
\text { analyze and understand their } \\
\text { business. (Hum \& Mec) } \\
\text { Managers use strategy to set } \\
\text { targets and objectives. (Mec) } \\
\text { Managers create sub- } \\
\text { strategies to secure and en- } \\
\text { sure that their unit is in line } \\
\text { with Industrial's strategy and } \\
\text { appears legitimized. (Hum \& } \\
\text { Mec) } \\
\text { Managers use Industrial's } \\
\text { strategy as a loose frame- } \\
\text { work, guideline, which } \\
\text { leaves them room to maneu- } \\
\text { ver with their own sub- } \\
\text { strategies. (Prag) }\end{array}$ & $\begin{array}{l}\text { Managers produce elegant } \\
\text { strategy papers for the City } \\
\text { Council to legitimize and } \\
\text { report organization's activi- } \\
\text { ties as an administrative task. } \\
\text { (Mec, Spir \& Prag) } \\
\text { Managers use strategy to } \\
\text { differentiate Polytechnic } \\
\text { from its competitors and } \\
\text { improve its brand. (Prag) } \\
\text { Managers use strategy to } \\
\text { build commitment and in- } \\
\text { volvement in their own units. } \\
\text { (Prag, Hum \& Spir) } \\
\text { Managers use strategy to } \\
\text { solve problems in their own } \\
\text { units. (Mec \& Prag) }\end{array}$ & $\begin{array}{l}\text { Managers use Insurance's } \\
\text { strategy as an intent that they } \\
\text { concretize and execute as a } \\
\text { part of their job as managers. } \\
\text { (Prag \& Mec) } \\
\text { Managers use Insurance's } \\
\text { strategy as a tool to motivate } \\
\text { and inspire their subordi- } \\
\text { nates. (Hum \& Spir) } \\
\text { Managers use Insurance's } \\
\text { strategy as a means to justify } \\
\text { and legitimize choices and } \\
\text { decisions. (Prag) }\end{array}$ \\
\hline $\begin{array}{r}\text { USAGE: } \\
\text { PLAYFUL TACTIC }\end{array}$ & $\begin{array}{l}\text { Managers question and joke } \\
\text { about the role of Industrial's } \\
\text { headquarters and top man- } \\
\text { agement as central strate- } \\
\text { gists. (Mec \& Spir) } \\
\text { Managers play with the cul- } \\
\text { tural differences between } \\
\text { different parts of Industrial, } \\
\text { preventing it from operating } \\
\text { coherently and realizing its } \\
\text { strategy in a desired way. } \\
\text { (Prag) }\end{array}$ & $\begin{array}{l}\text { Managers regard Polytech- } \\
\text { nic's strategy as poor in } \\
\text { quality. (Spir) } \\
\text { Managers construct admini- } \\
\text { stration-driven strategy work } \\
\text { and its mechanisms as un- } \\
\text { suitable and ridiculous for } \\
\text { Polytechnic. (Mec) }\end{array}$ & $\begin{array}{l}\text { Managers amuse themselves } \\
\text { by joking about the abstract } \\
\text { content of Insurance's strat- } \\
\text { egy. (Spir) } \\
\text { Managers ridicule the role of } \\
\text { Insurance's top management } \\
\text { and headquarters in strategy. } \\
\text { (Prag \& Spir) } \\
\text { Managers parody the meth- } \\
\text { ods used as symbols and } \\
\text { tools in Insurance's strategy } \\
\text { communication. (Spir) }\end{array}$ \\
\hline $\begin{array}{r}\text { USAGE: } \\
\text { INTIMATE TACTIC }\end{array}$ & $\begin{array}{l}\text { Managers use strategy to } \\
\text { glorify themselves as strate- } \\
\text { gic leaders. (Mil) } \\
\text { Managers outline how they } \\
\text { lack support in Industrial's } \\
\text { strategy process. (Hum \& } \\
\text { Prag) } \\
\text { Managers dis-identify them- } \\
\text { selves from Industrial's strat- } \\
\text { egy that does not concern } \\
\text { them. (Prag) }\end{array}$ & $\begin{array}{l}\text { Managers take risks and use } \\
\text { some half illegal tricks in } \\
\text { order to cope and maneuver } \\
\text { with Polytechnic's strategy. } \\
\text { (Prag \& Mec) } \\
\text { Managers feel themselves } \\
\text { intimidated, sidelined and } \\
\text { dominated in Polytechnic's } \\
\text { strategy work. (Hum) } \\
\text { Managers pass and ignore } \\
\text { Polytechnic's strategy } \\
\text { swiftly when considering it } \\
\text { unsuitable for themselves. } \\
\text { (Mec) }\end{array}$ & $\begin{array}{l}\text { Managers devote and submit } \\
\text { themselves to Insurance's } \\
\text { strategy. (Spir \& Mil) } \\
\text { Managers feel themselves } \\
\text { helpless and incapable in } \\
\text { front of Insurance's strategy. } \\
\text { (Prag) } \\
\text { Managers dis-identify them- } \\
\text { selves from Insurance's } \\
\text { strategy by silencing it and } \\
\text { ignoring some of its prac- } \\
\text { tices. (Prag) }\end{array}$ \\
\hline
\end{tabular}

To some extent, the whole idea of studying strategy usage like this contains and expresses a flavor of irony (Whittington 2007) by focusing on the neglected side of strategy practice. The rational, and to some extent, also the processual strategy approach have not paid enough concern to this kind of individuality in strategizing. This 
kind of individual activity may often be by-passed or ignored as trivial or nonsense or it may remain totally unseen, since it is often hidden and scattered within the existing structures and routines. The irony lies in the fact that strategy is (re)produced and acknowledged in one way and later used differently, as the results of this work showed. Again, macro-discourses of strategy can be used very ambiguously. They may say one thing, and mean something totally different. For instance, the mechanistic macrodiscourse can be used to either describe efficient mechanisms of strategy or to ridicule those very same systems harshly.

Table 14 summarizes the contribution of this work to the practice approach to strategy. The column on the left indicates the findings of prior research, and the column on the right defines how the results of this work seek to contribute to those findings.

TABLE 14 SUMMARY OF THE CONTRIBUTION TO THE PRACTICE-ORIENTED STRATEGY RESEARCH

\begin{tabular}{|c|c|}
\hline PRACTICE APPROACH & CONTRIBUTION OF THE STUDY \\
\hline \multirow{2}{*}{$\begin{array}{l}\text { Strategy work that is } \\
\text { done in organizations is } \\
\text { influenced and guided by } \\
\text { socially defined modes, } \\
\text { established by the strat- } \\
\text { egy industry. A research } \\
\text { approach that integrates } \\
\text { these micro and macro- } \\
\text { levels of strategy practice } \\
\text { is thus needed. (Jarzab- } \\
\text { kowski et al. 2007; Whit- } \\
\text { tington 2003, 2006, } \\
\text { 2007). }\end{array}$} & $\begin{array}{l}\text { Strategy, as an institutionalized management discipline, is practiced, consumed (de } \\
\text { Certeau 1988), by the managers in three case organizations. The two context-specific } \\
\text { and embedded micro-level discursive practices of strategy consumption, } \\
\text { (re)production and usage, are closely connected to the macro-level strategy dis- } \\
\text { courses present in the wider strategy and management literature. }\end{array}$ \\
\hline & $\begin{array}{l}\text { The integrative strategy consumption process deepens our understanding of how } \\
\text { strategy is practiced in organizations. The finding contributes to the practice ap- } \\
\text { proach to strategy by connecting the gap between the extra and intra-organizational } \\
\text { approaches to strategy practice and by showing what strategy consumption is in prac- } \\
\text { tice (Whittington 2003, 2006). The results show that strategy may be consumed and } \\
\text { used in more creative, improvisatory and contextual ways than the previous, namely } \\
\text { rational-oriented, strategy research has shown. }\end{array}$ \\
\hline
\end{tabular}

Strategic practices are used in creative ways by practitioners (Whittington 2003; Jarzabkowski 2004).
The strategy use of managers is context-specific and largely based on their individual and situational needs. The instrumental usage tactic uses strategy as an instrument to perform different managerial duties. The playful usage tactic does not do anything concrete with strategy, but plays and amuses the user with it. The intimate usage tactic attaches strategy to a manager by constructing one's personal relationship to it.

Strategic actions of managers may not arise from the intended and intentional strategies, as the purely rational though would suggest, but emerge through the everyday "practical coping" and "dwelling" of managers when things are labeled and regarded as strategic (cf. Chia \& Holt 2006). Strategy is an indefinite and versatile (and maybe even precarious) practice for managers, and they use and consume this practice in multiple ways and with means that may depart from the ideals that they themselves attach to it. (Cf. Whittington 2003.) Different kinds of ideals and models (macro-discourses) can be attached to it depending on the prevailing situation and needs.

Strategy practice includes The idea of studying strategy usage contains a flavor of irony (Whittington 2007) by ironies that should be covered by practiceoriented research (Whittington 2006). focusing on the neglected side of strategy practice. The irony lies in the fact that strategy can be (re)produced as one way and later used differently. Again, macrodiscourses of strategy can be used very ambiguously. They may say one thing, and mean something totally different. This kind of irony stems from the individuality of strategy practice. 


\subsection{STRATEGY CONSUMPTION AS DISCURSIVE ACTIVITY}

Besides making remarks to the practice approach to strategy, this work seeks to contribute to the discursive strategy research by showing how strategy consumption is a creative and artful discursive activity. The previous work on strategy discourse has already shown that strategy is not a unanimous discourse, but more likely consists of different kinds of (even contradictory) ideas and types of discourse (Laine \& Vaara 2007; Mantere \& Vaara 2008; Phillips et al. 2008). The results of this work show how different macro-discourses of strategy can co-exist within the same organization and be used tactically for different purposes by its managers. For instance, the spiritual macro-discourse is used widely as a resource to (re)produce strategy as a sacred journey into the intended vision of the organization. The same macro-discourse is, however, also used as a means to ridicule and joke about the role of the top management in strategy work, as is the case at Industrial and Insurance. This example shows how strategy discourses can be polysemic resources, having a number of meanings and ways of using them (Hardy et al. 2000), and that strategy consumption is a discursive accomplishment that capitalizes and appropriates the discursive space between the discursive structures (macro-discourses of strategy) and the user (manager).

In this work, managers seem to (re)produce strategy in rather similar ways in different case organizations (see Table 12 above), which recalls the ideas of the rational strategy approach. Here, strategy appears to managers mostly as a way or journey into the defined vision of the organization, which can be interpreted as a strong reference to the spiritual macro-discourse. Again, at every organization managers outline how strategy should concern the whole personnel and how it should get realized in the everyday actions of the organization, which refer to the humanistic and pragmatic macrodiscourses. To some extent, the mechanistic macro-discourse is also present in every case organization, as managers emphasize mechanisms and processes that relate to strategy. This finding confirms the Foucauldian $(1972,55)$ idea that discourses, as manifestations of power structures, dominate individuals. In practice, many managers do not have a choice whether or not to apply strategic practices in their work. Strategy is imposed on them by the zeitgeist that treats strategy as a superior management discipline (cf. Knights \& Morgan 1991; Ezzamel \& Willmott 2008), and the similarity found in the accounts of the strategy (re)production seems to indicate this. It may also 
reveal that certain root metaphors, such as the metaphor of the journey (Inns 1996), have been deeply embedded and institutionalized in the strategy discourse and became a socially accepted way to describe strategy. The journey metaphor seems to provide us with a means to describe the progress, direction and purpose of an organization (and its strategy) in a manner that makes sense to us.

However, the (re)production of strategy is only the other side of the strategy consumption process, since managers are also able to use and subvert strategy in creative ways, as the other discursive practice, strategy usage, shows (see Table 13 above). Strategy use is an area that has been somewhat neglected in the previous research on strategy discourse. Through these accounts of strategy usage we cannot only learn what is being done with strategy, but also how strategy is consumed stylistically by managers (de Certeau 1988). We learn that strategy usage is a discursive activity that poaches, combines, and utilizes different strategy discourses artfully.

As discussed in the previous chapter, the instrumental strategy usage stems largely from the contextual and situational needs of managers', departing from the rational ethos of strategy at some cases. The previous research on strategy discourse has identified several power effects of strategy (Knights \& Morgan 1991). The results of this work show how managers can subtly use and apply these power effects in practice. For instance, managers make strategies to appear important and legitimized to others (Industrial \& Polytechnic) and in this way use strategy to demonstrate their managerial rationality and ability. They also legitimize their exercise of power to their subordinates by using strategy to justify the choices and decisions that have been made (Insurance). These examples show how strategy discourse can be used to justify and legitimize many different things in organizational life (cf. Vaara \& Tienari 2002; Vaara et al. 2004).

Again, the playful and intimate strategy usage tactics depart even more clearly from the ideas of the strategy (re)production. These strategy usage tactics show how managers shape and consume strategy and strategic issues actively and individually. For instance, the playful usage tactic seems to be highly critical towards the top management in every case organization. At Polytechnic and Insurance, the content of the strategy and the methods and tools that are used in the strategy work are criticized harshly. It is also interesting to note how dis-identification becomes a central feature 
of the intimate strategy use in every organization, as managers seem to produce and construct their role as bystanders in strategy. Strategy usage like this does not produce any tangible or concrete results, and can thus often be regarded as unproductive. Nevertheless, as we have seen, they are anything but innocent or empty accounts, but colorful and interesting notions about cynicism and humor that are related to the strategy work and that may distance the practitioners from strategy or make them to disidentify from it (Fleming \& Spicer 2003; Mantere 2003). They certainly influence the way that managers act and master strategy in their work. Accounts of the playful and intimate strategy usage represent also very artful and skilful styles of using strategy discourses.

The discursive research on organizational discourse has been criticized of being too deterministic in its relation to agency. To some extent, it may have downplayed the role of agency in the construction, reproduction and transformation of discourse, by ignoring the fact that the individuals are not that passive and powerless as the Foucauldian tradition of the discourse analyses might have suggested. (Reed 2000.) This work outlines the agency of individual managers who use and appropriate strategy discourse in their everyday life actively and artfully. Although strategy discourse definitely "transforms managers [...] into subjects" and makes them follow principles of it (Knights \& Morgan 1991, 252), managers are also able to transform and subvert the strategy discourse to fit their own preferences and desires. By showing this kind of strategy consumption, this work stresses the dynamic relationship between discourse and power (Hardy \& Phillips 2004), and the dynamics between agency and structure, by showing that although macro-discourses have power over us we can use and (re)produce them in novel ways.

The intimate and playful strategy usage tactics tell us how the managers engage themselves in strategy personally, either struggling with its meaning to their subjectivity (Laine \& Vaara 2007) or using it to construct their identity. The struggles become most obvious in the case of the playful and intimate strategy usage. Especially playful strategy usage is in most parts rather cynical and critical towards strategy and its manifestations. By showing detailed descriptions of this kind of strategy usage, this work shows how managers resist strategy artfully. They use and appropriate the strategy discourse skillfully for their own purposes to resist and alternate it, while at the 
same time articulate and talk in ways that do not directly confront the dominant discursive regime (Mumby 2005). By doing this, they fix the meaning of strategy discourse and consume it in its own terms. This finding shows that resistance towards strategy is seldom evident and direct, but more likely implicit, hidden and playful by nature.

The previous work on strategy discourse has showed how different strategy discourses can either promote or prevent participation and engagement in strategy process (Mantere \& Vaara 2008). In the case of the intimate strategy usage, this work shows how the lack of chances for participation, and the lack of applicability of the strategy can make managers dis-identify themselves from it. On the other hand, the intimate strategy usage also shows how managers can engage themselves strongly in strategy with different discursive resources. For instance, the militaristic macro-discourse can be used to glorify managers as strategic leaders, and the combination of militaristic and spiritual macro-discourse can be used to construct managers as obedient and submissive foot soldiers or followers of strategy (cf. Knights \& Morgan 1991). These results support the finding that strategy discourse does not produce different subject positions to the individuals alone, but that also individuals can use strategy discourse to construct and consume their subjectivity (Laine \& Vaara 2007).

Table 15 summarizes the contribution of this work to the discursive strategy view. The left column indicates again the previous research findings, and the right column discusses how the results of this work contribute to them. 
TABLE 15 SUMMARY OF THE CONTRIBUTION TO DISCURSIVE STRATEGY RESERACH

DISCURSIVE VIEW CONTRIBUTION OF THE STUDY
ON STRATEGY

Strategy discourse creates organizational reality actions. Strategy discourse is not a unanimous project, but instead consists of different kinds of ideas and types of discourse (Mantere \& Vaara 2008).

Strategy discourse has several different power effects (Knights \& Morgan 1991).

Individual agency has by Foucauldian discursive strategy research (Reed 2000). determines and justifies 2008; Phillips et al. been somewhat neglected

Different macro-discourses of strategy co-exist within same organizations and are used tactically for different purposes by their managers. Strategy discourse is a polysemic resource having a number of meanings and ways of using it (cf. Hardy et al. 2000). Strategy consumption is a discursive accomplishment that capitalizes and appropriates the discursive space between the discursive structures (macrodiscourses of strategy) and the user (manager).

Through different strategy usage tactics (instrumental, playful, intimate) we cannot only learn what is being done with strategy, but also how strategy is consumed stylistically by managers (de Certeau 1988).

Managers can subtly use and apply these power effects in practice. For instance, they create strategies to appear important and legitimized to others (Industrial \& Polytechnic) and by this way use strategy to demonstrate their managerial rationality. They also legitimize their exercise of power to their subordinates by using strategy to justify the choices and decisions that have been made (Insurance). Hence, strategy discourse can be used to justify and legitimize many things in organizational life (cf. Vaara \& Tienari 2002; Vaara et al. 2004).

Managers (re)produce strategy rather unanimously, drawing on the ideas of the rational strategy approach. This confirms the Foucauldian idea that discourses, as manifestations of power structures, dominate individuals. However, the strategy usage shows how managers are also able to use and subvert strategy discourses with creative ways.

Although strategy discourse "transforms managers [...] into subjects" and makes them to follow principles of it (Knights \& Morgan 1991, 252), managers are also able to transform and appropriate the discourse to fit their own preferences and desires. This consumption of strategy stresses the dynamic relationship between discourse and power (cf. Hardy \& Phillips 2004) and the dynamics between agency and structure. By this way strategy discourse does not produce different subject positions to individuals alone, but also individuals can use strategy discourse to construct and consume their subjectivity (Laine \& Vaara 2007).

Strategy discourse can either promote or prevent participation in strategy work (Mantere \& Vaara 2008).
The lack of chances to participation and of applicability of the strategy can make managers to dis-identify themselves from strategy. On the other hand, intimate strategy usage shows how managers can also engage themselves strongly in strategy. For instance, the militaristic macro-discourse can be used to glorify the managers as strategic leaders and the combination of militaristic and spiritual macro-discourse can be used as a resource to construct managers as an obedient and submissive foot soldiers or followers of strategy (cf. Knights \& Morgan 1991). 


\section{CONCLUSIONS}

At the beginning of the introduction chapter, there was a quotation from the manager of Polytechnic, who said that he/she has been "fussing with the strategy" for 20 years. The aim of this work has been to cover and illustrate what this fussing is all about, that is, to study the consumption of strategy. The primary research question of the study was as follows:

- How do managers consume strategy in their talk?

And the secondary research questions were:

- What kinds of discursive recourses do managers use in strategy consumption?

- What kinds of discursive practices do managers use in the strategy consumption?

- How do managers consume strategy in the different case organizations?

The work begun with a classification of three theoretical approaches to strategy: rational, processual and practice. Each of them provided their own conception of strategy and the role of the managers' (Chapter 2). By drawing on the discursive view, the discursive perspective on strategy was also introduced, in order to understand how strategy is practiced discursively. The term consumption adopted from de Certeau (1988) was used as the theoretical framework to analyze the research data produced in three case organizations (Industrial, Polytechnic and Insurance), to understand and explain how managers use and apply macro-level strategy discourses in their everyday talk. 
During the research process (Chapter 3), I found that the managers consume strategy at two levels. (Re)production is a discursive practice that brings strategy into being by defining and describing it at the societal and organizational level with the use of the macro-discourses. Here managers define what strategy is to them. Strategy usage, on the other hand, is the discursive practice that applies and uses strategy for the managers' purposes and ends. It turns the Foucauldian idea of discourses as totalities more or less up-side-down by explaining how managers use strategy. Instrumental talk constructs strategy as a device, as an instrument that managers use as a means in their work. Playfulness represents rhetoric that distance managers from strategy and channels criticisms, disagreement, and/or frustration towards it. Intimate rhetoric describes managers' own personal feelings, such as fear, insecurity or faith, towards strategy.

Besides these two discursive practices, I also found that certain macro-discourses of strategy are used as resources in strategy consumption. The macro-discourses of strategy represent the structure that the managers use and consume. These five discourse types discuss the nature, conditions, and actors of strategy work in different ways. All of these discourses are imported discourses (cf. Phillips et al. 2008) in the sense that they are not only consumed in the case organizations but can also be indentified from the broader strategy discourse and most likely from other organizations as well.

By constructing a general strategy consumption framework (see Figure 6) along with illustrating how the elements of the framework are manifested in different case organizations (Chapters 4-7), I hope to have answered the research questions. As a conclusion, we could argue that managers consume strategy with more creative, contextspecific and original ways than has been previously acknowledged. The obvious differences between managers' accounts of the strategy (re)production and usage shows that while managers acknowledge strategy in a certain conventional way, they use it in ways that depart from this conventionalism. This is the art of practicing and using strategy. 


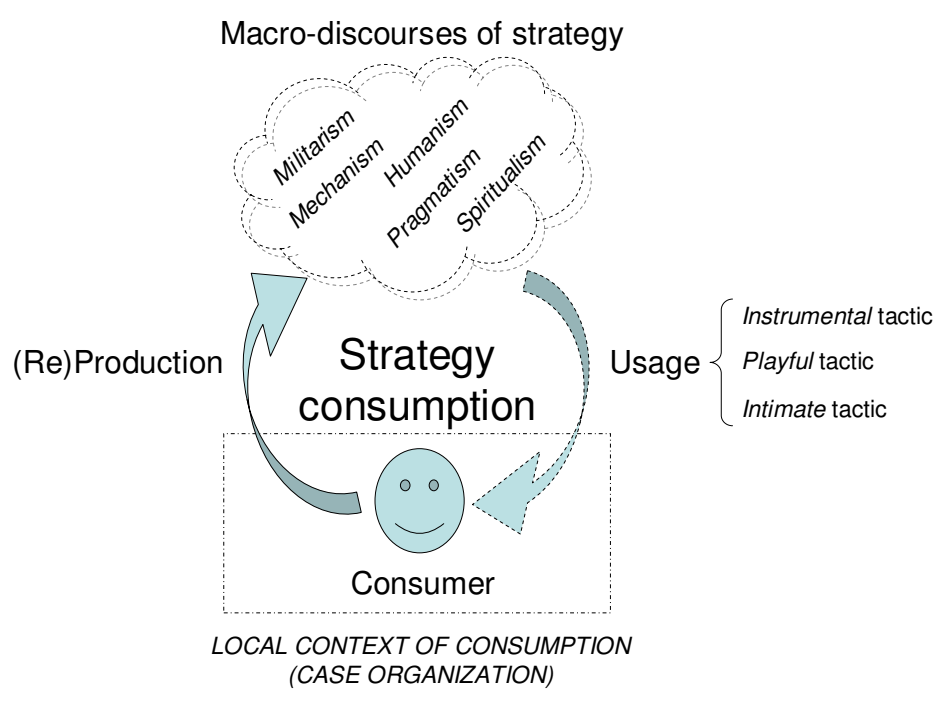

\section{FIGURE 6 STRATEGY CONSUMPTION FRAMEWORK}

The previous chapter discussed the theoretical relevance of the results. In the following, some practical recommendations are given based on the results. In terms of the practical relevance, two kinds of implications can be formulated from the results. Firstly, the results have something to say to the individual manager who is trying to cope with strategy in his/her everyday work. Secondly, some recommendations can also be made to organizations that are trying to manage and organize individuals, that is, strategy consumers. Finally, at the end of the chapter, the credibility of the findings is discussed and some further research questions are proposed.

\subsection{PRACTICAL IMPLICATIONS}

As the results show, an individual manager can consume strategy with multiple ways for his/her own benefit. For instance, the instrumental usage tactic has proven that strategy can be a versatile tool that can be used by managers for different functions and ends. For a new manager, strategy provides an opportunity to get to know his/her organization and its business conditions, as was the case at Industrial, where managers used strategy to analyze and learn about their business environment. It seems that while formulating strategy, managers are allowed to ask simple questions ("Who are our customers?") and to take some distance from their everyday work. At Industrial, managers also used strategy to set targets and objectives, both for themselves and their subordinates. At Insurance, managers used strategy as intent, which they concre- 
tized and executed as part of their jobs as managers. In these cases, strategy seemed to provide managers with the means to lead their people in a target-oriented way in an executive mode.

Strategy may also provide managers with a means to legitimize their own work, as was the case at Industrial and Polytechnic, where managers used strategy to ensure the meaningfulness and importance of their work, both for the internal and external stakeholders. At some points, it seemed that by not formulating their own strategy, managers risked losing their importance in and connectedness to the rest of the organization. At Insurance, strategy provided managers with a means to justify and explain different decisions and choices for their subordinates, who might from time to time question their relevance. In tough situations like this, strategy may provide managers with valuable support.

Strategy can also equip managers to influence the sense of meaningfulness felt by their subordinates. Both at Polytechnic and Insurance, managers sought to motivate their subordinates with strategy. It seems that strategy may provide a means to create a sense of meaningfulness and importance among subordinates, and in this way help managers to "win their hearts." At Polytechnic, strategy was also used for solving some central problems that managers faced in their units. When labeling a problem "strategic," managers may have used strategy to outline and highlight the importance of the problem and to create a sense of urgency for solving it.

In practice, managers spend plenty of their time communicating and interacting strategy with others. Strategy language is their resource for shaping issues and changes and for gaining influence over people. The way strategy is consumed and used by them influences and shapes the way others perceive strategy and their role in it. (Johnson et al. 2008, 17-22.) In this work, five different resource bases (macro-discourses of strategy) were identified and explained. This work may help managers to reflect on their own consumption styles of strategy and even equip them with some new ideas on how to use strategy in their talk. This can further improve their leadership skills and abilities.

However, my intention is not to say that managers should use strategy purely for their own interest and ends opportunistically, individualistically and unethically without 
paying attention to the benefits of others. From my viewpoint, strategy is often a team effort that requires cooperation, engagement and participation throughout the organization. An organization full of individual managers performing and consuming their own strategies driven mostly by their self-interests might be a dangerous and disastrous experiment, as the recent global credit crunch has shown.

This work has shown that strategy is consumed and used in ways that are more creative and original than is usually thought and considered. It is obvious that strategy consumption cannot be "managed," since it is part of our very human nature. However, too many variations in strategic management or in a corporate strategy within the same organization can cause chaos and disorder. This is why it might be useful to try to create coherence regarding how to lead and manage "strategically" within an organization. Strategy instructions or a user's manual might provide the needed coherence and coordination to organization's strategy praxis, in terms of the instrumental strategy use. Again, the coherence in the strategy rhetoric and usage of managers' increases the likelihood of creating commitment towards strategic targets (cf. Jarzabkowski \& Sillince 2007).

Here we cannot ignore the pessimism and criticism with which the playful tactic targets strategy. It seems that to a great deal this criticism stemmed from the fact that the managers felt themselves outsiders and disrespected (Mantere 2008) in their organizations' strategy work. Strategy may have appeared to them as ironic and odd, which made them distance themselves from it and to play with it. All criticism cannot be silenced, and neither should it be, since critical and playful strategy thinking, manifested in the playful tactic, may encourage and fuel innovative "out of the box" thinking, which may improve strategic renewal (cf. Burgelman 1983) in an organization. However, cynicism about strategy, which can be harmful for the organization, might be reduced by providing people with opportunities to influence and shape the structures they are using, as cynicism may originate from lacking or non-existing participation chances (cf. Mantere \& Vaara 2008). This is something that should be taken into account when planning strategy processes, since the way managers communicate strategy influences how their own subordinates understand and adopt it (Suominen, Karkulehto, Sipponen \& Hämäläinen 2009). 
With the case of the intimate tactic, the managers construct their subjectivity and identity in relation and with regard to strategy. This means that strategy is taken very seriously by many managers. In every case organization, there were managers who wanted to dis-identify themselves from strategy. At Polytechnic, some managers felt intimidated and humiliated by the strategy work. Previous research has shown (Guth \& MacMillan 1986) how the self-interest of middle managers' motivates their degree of commitment to strategy implementation. The evidence shows that middle managers, who believe that their self-interests are compromised, cannot only redirect strategy, delay its implementation or reduce the quality of its implementation, but also sabotage the entire strategy. (Ibid.) Based on this, it is easy to suggest that no-one should feel outsider or unimportant in strategy work.

\subsection{CREDIBILITY OF THE FINDINGS}

In this work, I have applied a discursive approach to strategy. Since discourse analysis is not a clear-cut research method as such, but more likely a field that allows different styles and approaches, a researcher needs to develop his/her own way of conducting a discourse analytic study. I chose to follow Fairclough's (1992) ideas when constructing a research and analysis design for this work, although I was not as critical towards the discursive structures as he might have been. Fairclough's approach merges different traditions of discourse analysis together, which suits my work fairly well. However, de Certeau's (1988) thinking and ideas about consumption have also influenced this work a great deal. The research data were produced in three case organizations during 2003-2008. In this work, I have tried to ensure the anonymity of both the case organizations and interviewed managers by writing the case descriptions in a way that makes them un-recognizable. By doing this, I hope to have ensured the ethicality of this work.

The credibility of the discourse analytic work like this, which draws on constructivism and post-structuralism (see Chapter 3), and seeks to follow the contextual reasoning strategy (cf. Ketokivi \& Mantere 2010), calls for increased reflexivity from the researcher conducting the research. Reflexivity means paying close concern to the ways in which the research is carried out. It requires understanding and reflecting on how 
the research process was carried out and how it has influenced and shaped its outcomes. In discursive research, both the results and the work itself are results of an interpretation. The research process of this work was described in Chapter 3.

Phillips and Hardy (2002, 83-85) have identified eight dimensions of reflexivity that should be acknowledged and reviewed when conducting a discourse analytic research. In the following, I will reflect and discuss those dimensions in terms of my own work. The first dimension, according to Phillips and Hardy, is to acknowledge that language constructs rather than reveals our social reality. This applies not only to the language used by the managers in this study, but also to the language that I have used when writing up this dissertation. (Ibid.) For instance, the case descriptions provided in Chapters 5-7, which described the contexts of consumption at the case organizations, are my personal constructions and interpretations of them, not objective accounts or reports on what they are "in reality." Some other person might have interpreted them differently and produced different kinds of descriptions. However, in this work I have tried to "validate" my descriptions and interpretations by asking my colleagues, who were present in the same organizations, to read and evaluate my case descriptions in order to reflect and compare whether they have interpreted the "facts" related to them in the same way. The feedback I received from them seems to confirm my findings. I also decided to use de Certeau's idea of consumption as the theoretical lens in this work, which means that it has influenced the work and its results. The results of this work, although produced empirically, stem from this paradigm and thinking, which means that the empirical evidence of strategy consumption has been constructed within this particular paradigm and line of thinking (Alvesson \& Kärreman 2007).

The second dimension of the reflexivity is to study and identify the historical processes that underline and interact with particular texts. This means that the researcher should recognize the broader historical discourses that influence the particular language use. (Phillips \& Hardy ibid.) In this research, I have showed how the discursive activity of the managers takes place in at least two kinds of contexts. Firstly, I have shown how the local contexts, here the atmosphere and situation of the case organizations, affect and influence the discursive activity of managers. Secondly, I have illustrated how the managers use different kinds of macro-discourses of strategy when (re)producing and using strategy in their talk. By showing this type of intertextuality 
(cf. Fairclough 1992, 124-136), I hope to have described how the construction of our social reality is a multilayer process including many levels and types of discourse that are highly interrelated to each other.

Thirdly, in order to be reflexive, the researcher should allow different voices to pervade the text (Phillips \& Hardy ibid.). Here, I have tried to locate different kinds of voices and even struggles that have been present in the data. Actually, the main idea of this work has been to cover those clandestine and often hidden tactics of consumption that may not comply with the spirit of the dominant strategy discourse and that are normally missed and by-passed in strategy research. For instance, the playful tactic presented in this work consists of talk that might often be silenced in many organizational contexts.

The fourth dimension outlines that not all possible voices appear in text that is being analyzed. Some actors and subject positions will remain necessarily invisible, while some others will be privileged. Phillips and Hardy (ibid.) outline how discourse cannot be studied in its entirety; only clues and small subsets of it can be found in texts. This also applies to this work, and might also be considered as its weakness. The discursive construction and consumption of strategy is studied in only three case organizations, and only some of their managers were interviewed for this work. Had there been more case organizations, more managers, and maybe even in different countries, the results might have been different. I also left some voices and comments out of the analyses by focusing clearly on the talk that was related to strategy and strategy work. To some extent, a discursive work like this is always an incomplete project in this sense.

The fifth dimension calls for multiple meanings and alternate representations that should be covered in the discourse analytic work (ibid.). In this work, I have distanced myself from the idea that the strategy consumption should be presented in plain terms. Instead, I have aimed at showing how the strategy consumption process is a diverse enterprise that embodies a number of different representations and rhetorical tactics. Even the usage tactics presented in this work are not totally equal and commensurable in terms of their content and form. The instrumental strategy usage is very different from the playful and intimate usages, and vice versa. Also, within the usage tactics there are different kinds of streams of usage that make them polyphonic. 
Sixthly, a discourse analytic work should engage in a debate among and between different theoretical communities and discussions (ibid.). In this work I have tried to follow this advice by reflecting the results and findings to different bodies of knowledge, such as to the practice approach to strategy and to the discursive strategy view previously in this work. I have also tried to stimulate practical strategy discussion by providing advice to individual managers and organizations in terms of the research findings in this work. Potter and Wetherell $(1984,171-172)$ call this the "fruitfulness" of research, which means the scope of an analytic scheme to make sense of new kinds of discourses and to create novel solutions. Again, Giddens (2006, 103-104) outlines how research should assign counter-intuitiveness, by which he means the ability and power of theory to break out of what common sense would suggest and provide a fresh and new perspective on a phenomenon that puzzles us. Here, I have tried to refresh strategy research by illustrating how managers use strategy discourse in novel and creative ways by using de Certeau's (1988) idea of consumption as a theoretical lens. As mentioned before, there are not many works that have applied this approach previously (cf. Jarzabkowski 2004; De la Ville \& Mounoud 2003), which already makes it an exciting and fresh perspective within strategy research.

Seventhly, Phillips and Hardy (ibid.) outline how a researcher applying the discursive approach should not hide behind dominant conventions or rhetoric, but instead take responsibility for his/her text as its author. I have sought to do this by writing this dissertation largely in the active voice, to outline the choices that I have made during the research process, and to make it as transparent for the reader as possible. Since there are no "ready-made analysis solutions" available for the researcher in the field of discourse analysis, the analysis has to be customized to fit the work in question and this framework needs to be explained in detail for the reader. In the fourth chapter of this work, I attempted to reveal the logic and progress of this research process.

Finally, Phillips and Hardy (ibid.) advise the researcher to be aware of the political aspects of the research process. That is, the researcher reporting his/her results is not only uncovering our social reality, but constructing it, which means using power. Here, I should be aware of my ideological and theoretical underpinnings that effect my interpretations and might renew some power effects. It should be remembered that I was involved rather heavily in the strategy work of the case organizations of this 
study, especially at Industrial and Insurance, where I worked as a consultant for almost two years. On the one hand, this may have provided me with some information and data that I would not have had produced otherwise. On the other hand, I was involved in their culture and discourse rather thoroughly, which may have influenced my interpretations and thinking. In any case, I have tried to describe my role in each case organization, which I hope will increase the credibility and reflectivity of this work.

\subsection{FURTHER RESEARCH}

As was mentioned, the fruitfulness of a research depends upon its ability to generate new ideas and stimulate further research (cf. Giddens 2006, 103-104). Based on the results of this work, at least four different paths for further research could be identified.

Firstly, in this work, strategy consumption has been studied at the level of top and middle managers. In order to broaden the scope, further research attempts should concentrate on the employee level. I am confident that strategy is consumed differently at the employee level, especially in the current times of economic recession, when strategy is used to justify difficult decisions. Thus, it would be interesting to compare how different groups within an organization consume strategy and strategic issues. There would certainly be some similarities and differences in the (re)production and usage of strategy, and it would be interesting to study how they affect organizations' success.

Secondly, it would be interesting to take a more ethnographical and longitudinal approach to strategy consumption, and to study how a group of managers (and employees) would consume strategy in their talk during a longer period of time. This kind of approach would increase our understanding on how usage tactics evolve and change over time. It would be also interesting to study how individuals use different kinds of consumption tactics in different forums and platforms when addressing strategy to different audiences. 
Thirdly, it would be interesting to concentrate on a single strategy usage tactic presented in this work, for instance the playful strategy use, and study how it is manifested in different organizations and contexts. The playful strategy usage embodies an interesting form of resistance towards strategy and thus it would be interesting to study what provokes and fuels this kind of consumption. The more I think about playfulness in the strategy consumption, the more aware I become of the fact that I am also a rather playful strategy consumer myself. To me, playfulness seems to provide a break from everyday routines and a way to approach possible problems and deadlocks by means of humor.

One of the limitations of this work is the fact that strategy consumption has been studied at the level of the strategic management practice. We still know rather little about how certain individual strategic practices, such as the Balanced Score Card or Porter's Five Forces, are used in different contexts and situations. Further research should thus narrow its scope and focus on a single practice or practices and study how they are used as strategy practices. 


\section{REFERENCES}

Aaltonen, P. 2007. Adoption of Strategic Goals. Exploring the Success of Strategy Implementation through Organizational Activities. HUT Industrial Management and Work and Organizational Psychology Dissertation Series 2007/3. Espoo: Helsinki University of Technology.

Alvesson, M. 2003. Beyond Neopositivists, Romantics, and Localists: A Reflexive Approach to Interviews in Organizational Research. The Academy of Management Review 28(1), 13-33.

Alvesson, M. \& Kärreman, D. 2000a. Varieties of Discourse: On the Study of Organizations through Discourse Analysis. Human Relations 53(9), 1125-1149.

Alvesson, M. \& Kärreman, D. 2000b. Taking the Linguistic Turn in Organizational Research. Challenges, Responses, Consequences. The Journal of Applied Behavioral Science 36(2), 136-158.

Alvesson, M. \& Sköldberg, K. 2000. Reflexive Methodology. New Vistas for Qualitative Research. London: Sage Publications.

Alvesson, M. \& Kärreman, D. 2007. Constructing Mystery: Empirical Matters in Theory Development. Academy of Management Review 32(4), 1265-1281.

Alvesson, M. \& Kärreman, D. 2008. On the Social Nature of Explicating Mystery Construction in Theory Development: A Response to McKinley. Academy of Management Review 33(2), 543-545.

Andrews, K. R. 1980. The Concept of Corporate Strategy. Homewood, IL: Dow Jones-Irwin. 
Ansoff, H. I. 1984. Implanting Strategic Management. Englewood Cliffs, NJ: Prentice Hall.

Ansoff, H. I. 1965. Corporate Strategy. New York: McGraw-Hill.

Argyris, C. 1989. Strategy Implementation: An Experience in Learning. Organizational Dynamics 18(2), 5-15.

Ashforth, B. E. \& Pratt, M. G. 2003. Institutionalized spirituality as an oxymoron? In R. A. Giacalone, C. L. Jurkiewicz (eds.) Handbook of Workplace Spirituality and Organizational Performance (pp. 93-107). Armonk, NY: M.E. Sharpe.

Balogun, J. 2003. From Blaming The Middle to Harnessing its Potential: Creating Change Intermediaries. British Journal of Management 14(1), 69-83.

Barry, M. \& Elmes, M. 1997. Strategy Retold: Toward a Narrative View of Strategic Discourse. The Academy of Management Review 22(2), 429-452.

Berger, P. \& Luckmann, T. 1967. The Social Construction of Reality. London: Penguin.

Bourgeois, L. J. III. \& Brodwin, D. R. 1984. Strategic Implementation: Five Approaches to Elusive Phenomenon. Strategic Management Journal 5(3), 241264.

Bracker, J. 1980. The Historical Development of the Strategic Management Concept. The Academy of Management Review, 5(2), 219-224.

Burgelman, R. A. 1983. A Model of the Interaction of Strategic Behavior, Corporate Context, and the Concept of Strategy. Academy of Management Review 8(1), 61-70.

Burr, V. 1995. An Introduction to Social Constructionism. London: Routledge.

Carroll, S. 2000. Implementing Strategic Plans through Formalized Goal Setting. In P. C. Flood, T. Dromgoole, S. J. Carroll \& L. Gorman Managing Strategy Implementation (pp. 44-56). Oxford: Blackwell.

Carter, C., Clegg, S. R. \& Kornberger, M. 2008. Strategy as Practice? Strategic Organization 6(1), 83-99. 
Chaffee, E. E. 1985. Three Models of Strategy. The Academy of Management Review 10(1), 89-98.

Chandler, A. D. 1962. Strategy and Structure. Cambridge, MA: MIT Press.

Chia, R. 2000. Discourse Analysis as Organizational Analysis. Organization 7(3), $513-518$.

Chia, R. \& Holt, R. 2006. Strategy as Practical Coping: A Heideggerian Perspective. Organization Studies 27(5), 635-655.

Chia, R. \& Holt, R. 2009. Strategy Without Design. The Silent Efficacy of Indirect Action. Cambridge, UK: Cambridge University Press.

Clark, T. 2004. Strategy viewed from a management fashion perspective. European Management Review 1(1), 105-111.

Cyert, R. M. \& March, J. M. 1963. A Behavioral Theory of the Firm. Englewood Cliffs, NJ: Prentice Hall.

Crossan, M. M. \& Berdrow, I. 2003. Organizational Learning and Strategic Renewal. Strategic Management Journal 24(11), 1087-1105.

Crossan, M. M., Lane, H. W. \& White, R. E. 1999. An Organizational Learning Framework: From Intuition to Institution. Academy of Management Review 24(3), 522-537.

De Certeau, M. 1980. On the Oppositional Practices of Everyday Life. Social Text 3(Autumn 1980), 3-43.

De Certeau, M. 1988. The Practice of Everyday Life. Berkeley, CA: University of California Press.

De La Ville, V-I. \& Mounoud, E. 2003. How Can Strategy Be a Practice? Between Discourse and Narration. In B. Czarniawska (ed.) Narratives We Organize By (pp. 95-113). Philadelphia, PA: John Benjamins Publishing Company.

Eriksson, P. \& Lehtimäki, H. 2001. Strategy Rhetoric in City Management. How the Presumptions of Classic Strategic Management Live On? Scandinavian Journal of Management 17(2), 201-233. 
Ezzamel, M. \& Willmott, H. 2008. Strategy as Discourse in a Global Retailer: A Supplement to Rationalist and Interpretive Accounts. Organization Studies 29(02), 191-217.

Fairclough, N. 1992. Discourse and Social Change. Cambridge, UK: Polity Press.

Fairclough, N. 2005. Discourse Analysis in Organization Studies: The Case for Critical Realism. Organization Studies 26(6), 915-939.

Featherstone, M. 2007. Consumer Culture and Postmodernism. Second Edition. London: Sage.

Fiske, J. 1989. Understanding Popular Culture. London: Routledge.

Fleming, P. \& Sewell, G. 2002. Looking for the Good Soldier, Svejk: Alternative Modalities of Resistance in the Contemporary Workplace. Sociology 36(4), 857-873.

Fleming, P. \& Spicer, A. 2003. Working at a Cynical Distance: Implications for Power, Subjectivity and Resistance. Organization 10(1), 157-179.

Floyd, S. W. \& Wooldridge, B. 1992. Middle Management Involvement in Strategy and its Association with Strategic Type: A Research Note. Strategic Management Journal, 13(S1), 153-167.

Foucault, M. 1972. Archaeology of knowledge. New York: Pantheon.

Giddens, A. 2006. Sociology. Fifth edition. Cambridge, UK: Polity press.

Gioia, D. A. \& Chittipeddi, K. 1991. Sensemaking and Sensegiving in Strategic Change Initiation. Strategic Management Journal 12(6), 433-448.

Grandy, G. \& Mills, A. J. 2004. Strategy as Simulacra? A Radical Reflexive Look at the Discipline and Practice of Strategy. Journal of Management Studies 41(7), 1153-1170.

Grant, D., Keenoy, T. \& Oswick, C. 2001. Organizational Discourse: Key Contributions and Challenges. International Studies of Management \& Organization $31(3), 5-24$. 
Grant, D., Hardy, C., Oswick C. \& Putnam, L. L. 2004. Introduction: Organizational Discourse: Exploring the Field. In D. Grant, C. Hardy, C. Oswick \& L. Putnam (eds.) The Sage Handbook of Organizational Discourse (pp. 1-36). London: Sage.

Guth, W. D. \& MacMillan, I. C. 1986. Strategy Implementation Versus Middle Management Self-interest. Strategic Management Journal 7(4), 313-327.

Hamel, G. 2007. The Future of Management. Boston, MA: Harvard Business School Press.

Hardy, C. 2001. Researching Organizational Discourse. International Studies of Management \& Organization 31(3), 25-47.

Hardy, C., Palmer, I. \& Phillips, N. 2000. Discourse as a Strategic Resource. Human Relations 53(9), 1227-1248.

Hardy, C. \& Phillips, N. 2004. Discourse and Power. In D. Grant, C. Hardy, C. Oswick \& L. Putnam (eds.) The Sage Handbook of Organizational Discourse (pp. 299-316). London: Sage Publications.

Hart, S. L. 1992. An Integrative Framework for Strategy-Making Processes. Academy of Management Review 17(2), 327-351.

Hatch, M. J. 1997. Irony and the Social Construction of Contradiction in the Humor of a Management Team. Organization Science 8(3), 275-288.

Hendry, J. 2000. Strategic Decision Making, Discourse, and Strategy as Social Practice. Journal of Management Studies 37(1), 956-977.

Heracleous, L. \& Barrett, M. 2001. Organizational Change as Discourse: Communicative Actions and Deep Structures in the Context of IT Implementation. Academy of Management Journal 44(4), 755-778.

Hämäläinen, V. 2007. Struggle Over "Who We Are" - A Discursive Perspective on Organizational Identity Change. HUT Industrial Management and Work and Organizational Psychology Dissertation Series 2007/4. Espoo: Helsinki University of Technology.

Ikävalko, H. 2005. Strategy Process in Practice. Practices and Logics of Action of Middle Managers in Strategy Implementation. HUT Industrial Management 
and Work and Organizational Psychology Dissertation Series 2005/1. Espoo: Helsinki University of Technology.

Inns, D. 1996. Organisation Development as a Journey. In C. Oswick, D. Grant (eds.). Organisation Development, Metaphorical Explorations (pp. 20-34). London: Pitman.

Jarzabkowski, P. 2004. Strategy as Practice: Recursiveness, Adaptation, and Practices-in-Use. Organisation Studies 25(4), 529-560.

Jarzabkowski, P. 2005. Strategy as Practice: An Activity-Based Approach. London: Sage Publications.

Jarzabkowski, P., Balogun, J. \& Seidl, D. 2007. Strategizing: The Challenges of a Practice Perspective. Human Relations 60(1), 5-27.

Jarzabkowski, P. \& Sillince, J. 2007. A Rhetoric-in-Context Approach to Building Commitment to Multiple Strategic Goals. Organization Studies 28(11), 16391665.

Johnson, G., Scholes, K. \& Whittington, R. 2008. Exploring Corporate Strategy. Eight edition. London: Prentice Hall.

Juuti, P. \& Luoma, M. 2009. (In Finnish) Strateginen johtaminen. Helsinki: Otava.

Ketokivi, M. \& Mantere, S. 2010. Two Strategies for Inductive Reasoning in Organizational Research. Academy of Management Review 35(2), forthcoming.

Kim, W. C. \& Mauborgne, R. 2005. Blue Ocean Strategy: How to Create Uncontested Market Space and Make the Competition Irrelevant. Boston, Harvard: Business School Press.

Knights, D. \& Morgan, G. 1990. The Concept of Strategy in Sociology: A Note of Dissent. Sociology 24(3), 475-483.

Knights, D. \& Morgan, G. 1991. Corporate Strategy, Organizations, and Subjectivity: A Critique. Organisation Studies 12(2), 251-273.

Knights, D. \& Morgan, G. 1995. Strategy Under Microscope: Strategic Management and It in Financial Services. Journal of Management Studies 32(2), 191-214. 
Knights, D. \& Mueller, F. 2004. Strategy as a 'Project': Overcoming Dualisms in the Strategy Debate. European Management Review 1(1), 55-61.

Laine, P-M. \& Vaara, E. 2007. Struggling Subjectivity: A Discursive Analysis of Strategic Development in an Engineering Group. Human Relations 60(1), 2958.

Lindblom, C. E. 1959. The Science of "Muddling Through". Public Administration Review, Vol. 19(2), 79-88.

Maitlis, S. \& Lawrence, T. B. 2003. Orchestral Manoeuvres in the Dark: Understanding Failure in Organizational Strategizing. Journal of Management Studies 40(1), 109-140.

Mantere, S. 2003. Champion, Citizen, Cynic? Social Positions in the Strategy Process. HUT Industrial Management and Work and Organizational Psychology Dissertation Series No 5. Espoo: Helsinki University of Technology.

Mantere, S. 2005. Strategic Practices as Enablers and Disablers of Championing Activity. Strategic Organization 3(2), 157-184.

Mantere, S. 2008. Role Expectations and Middle Manager Strategic Agency. Journal of Management Studies 45(2), 294-316.

Mantere, S. \& Sillince, J. 2007. Strategic Intent as a Rhetorical Device. Scandinavian Journal of. Management 23(4): 406-423.

Mantere, S. \& Vaara, E. 2008. On the Problem of Participation in Strategy: A Critical Discursive Perspective. Organization Science 19(2), 341-358.

March, J. \& Simon, H. 1958. Organizations. New York: John Wiley.

March, J. G. 1991. Exploration and Exploitation in Organizational Learning. Organization Science 2(1), 71-87.

Mintzberg, H. 1981. What is Planning Anyway? Strategic Management Journal 2(3), 319-324.

Mintzberg, H. 1987. Strategy Concept II: Another Look at Why Organizations Need Strategies. California Management Review 30(1), 25-32. 
Mintzberg, H. 1990. The Design School: Reconsidering the Basic Premises of Strategic Management. Strategic Management Journal 11(3), 171-195.

Mintzberg, H. Ahlstrand, B. \& Lampel, J. 1998. Strategy Safari. A Guided Tour Through the Wilds of Strategic Management. London: Prentice Hall.

Mintzberg, H. \& Waters, J. 1985. Of Strategies, Deliberate, and Emergent. Strategic Management Journal 6(3), 257-272.

Mir, R. \& Watson, S. 2000. Strategic Management and the Philosophy of Science: The Case for a Constructivist Methodology. Strategic Management Journal 21(9), 941-953.

Mitchell, J. P. 2007. A Fourth Critic of the Enlightenment: Michel de Certeau and the ethnography of subjectivity. Social Anthropology 15(1), 89-106.

Morgan, G. 1997. Images of Organization. Second edition. Thousand Oaks, CA: Sage Publications.

Mumby, D. K. 2004. Discourse, Power and Ideology: Unpacking the Critical Approach. In D. Grant, C. Hardy, C. Oswick \& L. Putnam (eds.) The Sage Handbook of Organizational Discourse (pp. 237-258). London: Sage Publications.

Mumby, D. 2005. Theorizing Resistance in Organization Studies. A Dialectical Approach. Management Communication Quarterly 19(1), 19-44.

Nordqvist, M. \& Melin, L. 2008. Strategic Planning Champions: Social Craftspersons, Artful Interpreters and Known Strangers. Long Range Planning 41(3), 326-344.

Nutt, P. C. (1986) Tactics of Implementation. Academy of Management Journal 29(2), 230-261.

Ocasio, W. \& Joseph, J. 2008. Rise and Fall - or Transformation? The Evolution of Strategic Planning at the General Electric Company, 1940-2006. Long Range Planning 41(3), 248-272.

Oswick, C., Keenoy, T. W. \& Grant, D. 2000. Discourse, Organizations and Organizing: Concepts, Objects and Subjects. Human Relations 53(9), 1115-1123. 
Pettigrew, A. M. 1992. The Character and Significance of Strategy Process Research. Strategic Management Journal 13(Special winter issue), 5-16.

Pfeffer, J. 2003. Business and the Spirit: Management Practices That Sustain Values. In R. A. Giacalone, C. L. Jurkiewicz (eds.) Handbook of Workplace Spirituality and Organizational Performance (pp. 29-45). Armonk, NY: M.E. Sharpe.

Phillips, N. \& Hardy, C. 2002. Discourse Analysis. Investigating Processes of Social Construction. Qualitative Research Methods Series 50. London: Sage Publications.

Phillips, N., Sewell, G. \& Jaynes, S. 2008. Applying Critical Discourse Analysis in Strategic Management Research. Organizational Research Methods 11(4), 770-789.

Potter, J. \& Wetherell, M. 1987. Discourse and Social Psychology. Beyond Attitudes and Behavior. London, Sage Publications.

Reed, M. 2000. The Limits of Discourse Analysis in Organizational Analysis. Organization 7(3), 524-530.

Regnér, P. 2003. Strategy Creation in the Periphery: Inductive Versus Deductive Strategy Making. Journal of Management Studies 40(1), 57-82.

Rouleau, L. 2005. Micro-Practices of Strategic Sensemaking and Sensegiving: How Middle Managers Interpret and Sell Change Every Day. Journal of Management Studies 42(7), 1413-1441.

Samra-Fredericks, D. 2003. Strategizing as Lived Experience and Strategists' Everyday Efforts to Shape Strategic Direction. Journal of Management Studies 40(1), 141-174.

Samra-Fredericks, D. 2004. Managerial Elites Making Rhetorical and Linguistic 'Moves' for a Moving (Emotional) Display. Human Relations 57(9), 11031143.

Seidl, D. 2007. General Strategy Concepts and the Ecology of Strategy Discourses: A Systemic-Discursive Perspective. Organization Studies 28(2), 197-218.

Silverman, D. 2006. Interpreting Qualitative Data. Third Edition. London: Sage Publications. 
Smircich, L. \& Stubbart, C. 1985. Strategic Management in an Enacted World. The Academy of Management Review 10(4), 724-736.

Suominen, K., Karkulehto, K., Sipponen, J. \& Hämäläinen, V. 2009. (In Finnish) Esimies strategiavaikuttajaksi. Helsinki: WSOYpro.

Vaara, E., Kleymann, B. \& Seristö, H. 2004. Strategies as Discursive Constructions: The Case of Airline Alliances. The Journal of Management Studies, 41(1), 135.

Vaara, E. \& Tienari, J. 2002. Justification, Legitimization and Naturalization of Mergers and Acquisitions: A Critical Discourse Analysis of Media Texts. Organization 9(2), 275-304.

Volberda, H. W. 2003. Strategic Flexibility. Creating Dynamic Competitive Advantages. In D. O. Faulkner \& A. Campell (eds.) The Oxford Handbook of Strategy. A Strategy Overview and Competitive Strategy. Oxford, UK: Oxford University Press.

Weick, K. E., 1995. Sensemaking in Organizations. London: Sage Publications.

Westley, F. R. 1990. Middle Managers and Strategy: Microdynamics of Inclusion. Strategic Management Journal 11(5), 337-351.

Whittington, R. 1996. Strategy as Practice. Long Range Planning 29(5), 731-735.

Whittington, R. 2001. What is Strategy - And Does it Matter? Second Edition. London: Thomson Learning.

Whittington, R. 2003. The Work of Strategizing and Organizing: For a Practice. Strategic Organization 2003(1), 117-125.

Whittington, R. 2006. Completing the Practice Turn in Strategy Research. Organisation Studies 27(5), 613-634.

Whittington, R. \& Cailluet, L. 2008. The Crafts of Strategy. Special Issue Introduction by the Guest Editors. Long Range Planning 41(3), 241-247. 


\section{APPENDICES}

\subsection{APPENDIX 1: INTERVIEW OUTLINE OF INDUSTRIAL}

The interviewee: title, job description and group/department

Have there been significant changes in your work lately? What kinds of changes?

1 How do you perceive Industrial's future?

2 What do you understand by the term strategy? (What is associated with strategy?)

3 What do you understand by the term strategy implementation? (What is associated with strategy implementation?)

4 What do you understand by the term strategy process? (What is associated with strategy implementation?)

5 Who creates Industrial's strategy? (How do they create it?)

6 Who realizes Industrial's strategy? (How do they realize it?)

6.1 What kinds of participation opportunities do they have in Industrial's strategy process?

6.2 What is your / your unit's role in the Industrial's strategy process?

7 Which events are most important at Industrial's strategy process?

8 How familiar you are with this figure? (The interviewer shows a picture of Industrial's strategy process.) 
9 Could you explain briefly how the strategy process operates?

10 How is Industrial's strategy shared into business plans?

11 What is done in your site / BU / area of responsibility

11.1 How well does this part of the strategy process work?

12 How are the business plans linked to sites' priorities?

12.1 What is done in your site / BU / area of responsibility

12.2 How well does this part of the strategy process work?

13 How are the team and personal plans linked to sites' priorities?

13.1 What is done in your site / BU / area of responsibility

13.2 How well does this part of the strategy process work?

14 What kind of feedback channels can be found between the company center, BUs and sites?

15 How well does Industrial's current strategy process work?

16 What are the weaknesses of the Industrial's strategy process? Explain!

17 What are the strengths of the Industrial's strategy process? Explain!

18 Does Industrial offer enough resources in order to realize its strategy?

19 Is Industrial's strategy realize in a desired way?

20 Does Industrial's organization structure promote strategy realization?

Any questions or comments? Thank you! 


\subsection{APPENDIX 2: INTERVIEW OUTLINES OF POLYTECHNIC}

\section{INTERVIEW OUTLINE FOR THE TOP MANAGERS}

1 How do you perceive the future of Polytechnic?

2 What do you understand by the term strategy? (What is associated with strategy?)

3 What do you understand by the term strategy implementation? (What is associated with it?)

4 How do you participate in Polytechnic's strategy process? (Strategy work)

5 How would you define your role in strategy implementation?

6 How do you communicate strategies? What practices are related to the strategy communication?

7 How well do you know Polytechnic's strategy? (What is associated with it?)

8 Are there problems with strategy implementation? (Questionnaire 3)

9 How do you perceive the ability of Polytechnic personnel's to participate in the strategy process?

10 How and what kind of feedback do you get from your subordinates related to strategy? (Tell a concrete example.)

11 What kinds of discoveries and findings have you made in your work that relate to the strategy? (How did it happen and why? Where did it lead on to?)

12 What is meant by R\&D operations in your opinion (at Polytechnic)?

13 What is the role of the R\&D operations in Polytechnic's strategy?

14 Why are R\&D operations important for Polytechnic? 
15 What have you done to promote $R \& D$ operations in the education processes at your faculty? (Questionnaire 1. Pick the methods that you have used and choose the five best.)

About these five methods:

16 Why do they work well?

17 Who has participated in these methods? (In what way?)

18 In which other situations and with who have you discussed R\&D operations at Polytechnic?

19 What have you done to promote the R\&D operations in education?

20 How do you know that Polytechnic's personnel have adopted the idea of R\&D operations?

21 Which matters associated with R\&D operations have been the most difficult to explain to the personnel?

22 What kinds of discoveries and findings have your subordinates made that relate to the R\&D operations? (Tell a concrete example.)

23 What have you done to ensure that the members of the personnel have interpreted the idea of the R\&D operations in a parallel manner?

24 What kinds of abilities (competence) are required from Polytechnic's with regard to the $R \& D$ operations?

25 On what level would you say that these abilities are at present?

26 How are R\&D operations present in Polytechnic's objectives?

27 In what way are $R \& D$ operations present in Polytechnic's work practices right now?

28 In what way should R\&D operations be present in Polytechnic's work practices right now? 
29 What is the most central content that you have communicated to Polytechnic's personnel concerning R\&D operations?

30 What sorts of goals have been set for your work? Who has set them? How are $\mathrm{R} \& \mathrm{D}$ operations present in these goals?

31 How are the R\&D operations present in your work? (Please provide an example.)

32 Do you feel that you have been given a sufficient opportunity for influencing the goals related to $\mathrm{R} \& \mathrm{D}$ operations?

(If not: how would you have wanted to influence them?)

33 In your opinion, what is the single most important thing that should be done to promote R\&D operations at Polytechnic?

34 Does Polytechnic's strategy realize in a desired way?

Questions? Comments? Were the questions difficult? Thank you! 


\section{INTERVIEW OUTLINE FOR THE MIDDLE MANAGERS}

1 How do you perceive the future of Polytechnic?

2 What do you understand by the term strategy? (What is associated with strategy?)

3 What do you understand by the term strategy implementation? (What is associated with it?)

4 How do you participate in Polytechnic's strategy process? (Strategy work)

5 How would you define your role in strategy implementation?

6 How do you communicate strategies to your subordinates? What practices are related to the strategy communication?

7 Are there problems with strategy implementation? (Questionnaire 3)

8 How do you perceive the Polytechnic personnel's ability to participate in the strategy process?

9 How and what kind of feedback do you give to your supervisor related to strategy? (Please give a concrete example.)

10 How and what kind of feedback do you get from your subordinates related to strategy? (Tell a concrete example.)

11 What is meant by R\&D operations in your opinion (at Polytechnic)?

12 What is the role of R\&D operations in Polytechnic's strategy?

13 Why R\&D operations are important for Polytechnic?

14 In what occasion did you get to know about the role R\&D operations in education?

15 Are there things related to $\mathrm{R} \& \mathrm{D}$ operations that are unclear? What are those things? 
16 What kinds of discoveries and findings have you made in your work that relate to the strategy? (How did it happen and why? Where did it lead on to?)

17 In which other situations and with who have you discussed R\&D operations at Polytechnic?

18 How the understanding of the role of R\&D operations has been supported?

19 How do you know that Polytechnic's personnel have adopted the idea of R\&D operations?

20 Which matters associated with R\&D operations have been the most difficult to explain to the personnel?

21 What have you done to ensure that the members of the personnel have interpreted the idea of $R \& D$ operations in a parallel manner?

22 What kinds of discoveries and findings have your subordinates made that relate to R\&D operations? (Please, tell a concrete example.)

23 What kinds of abilities (competence) are required from Polytechnic's personnel with regard to R\&D operations?

24 How are R\&D operations present in Polytechnic's objectives?

25 In what way are R\&D operations present in Polytechnic's work practices right now?

26 In what way should R\&D operations be present in Polytechnic's work practices right now?

27 What have you done to promote $R \& D$ operations in the education processes at your faculty? (Questionnaire 1. Pick the methods that you have used and choose the five best.)

About these five methods:

28 Why do they work well? 
29 Who has participated in these methods? (In what way?)

30 What is the most central content that you have communicated to Polytechnic's personnel concerning R\&D operations?

31 What sorts of goals have been set for your work? Who has set them? How are $\mathrm{R} \& \mathrm{D}$ operations present in these goals?

32 In what ways do you realize R\&D operations in education?

33 What motivates you to realize R\&D operations in education?

34 Do you feel that you have been given a sufficient opportunity for influencing the goals related to $\mathrm{R} \& \mathrm{D}$ operations?

(If not: how would you have wanted to influence them?)

35 Do you believe in the realization of $R \& D$ operations in education?

36 In your opinion, what is the single most important thing that should be done to promote R\&D operations at Polytechnic?

37 Does Polytechnic's strategy realize in a desired way?

Questions? Comments? Were the questions difficult? Thank you! 
QUESTIONNAIRE 1: IN WHAT WAY HAVE YOU CONTRIBUTED TO THE PROMOTION OF THE R\&D OPERATIONS AT POLYTECHNIC?

\begin{tabular}{|c|c|}
\hline \multicolumn{2}{|l|}{ Communication } \\
\hline Meetings & \\
\hline Briefings & \\
\hline Letters and communications & \\
\hline Notice boards & \\
\hline Internal magazines & \\
\hline Intranet & \\
\hline Mailing lists (e-mail) & \\
\hline \multicolumn{2}{|l|}{ Unofficial discussions } \\
\hline With superiors & \\
\hline With subordinates & \\
\hline With co-workers (associates) & \\
\hline \multicolumn{2}{|l|}{ Cultural phenomena } \\
\hline Stories & \\
\hline Symbols & \\
\hline Slogans & \\
\hline \multicolumn{2}{|l|}{ Personnel development } \\
\hline Training & \\
\hline Goal-setting discussions & \\
\hline Socialization / breaking in & \\
\hline Personnel choices & \\
\hline Rewarding & \\
\hline \multicolumn{2}{|l|}{ Planning } \\
\hline Budget monitoring and control & \\
\hline Business plans & \\
\hline Operational and performance objectives & \\
\hline \multicolumn{2}{|l|}{ Operations/processes } \\
\hline Project management systems & \\
\hline Quality systems & \\
\hline Changes in organizational structure & \\
\hline Networks and partnerships & \\
\hline
\end{tabular}




\section{QUESTIONNAIRE 3: PROBLEMS IN STRATEGY IMPLEMENTATION}

The problems presented in the list below are typical to many organizations. Please assess the weight of these problems in strategy implementation at Polytechnic.

\begin{tabular}{|c|c|c|c|c|c|}
\hline & $\begin{array}{l}\text { I don't } \\
\text { know }\end{array}$ & $\begin{array}{c}\text { Not a } \\
\text { problem }\end{array}$ & $\begin{array}{l}\text { A small } \\
\text { problem }\end{array}$ & $\begin{array}{l}\text { A rela- } \\
\text { tively big } \\
\text { problem }\end{array}$ & $\begin{array}{c}\text { A big } \\
\text { problem }\end{array}$ \\
\hline \multicolumn{6}{|l|}{ Feasibility of the strategy } \\
\hline $\begin{array}{l}\text { The strategy is not applicable in every part of the } \\
\text { organization }\end{array}$ & 0 & 1 & 2 & 3 & 4 \\
\hline $\begin{array}{l}\text { Different areas/issues in the strategy are in con- } \\
\text { flict with each other }\end{array}$ & 0 & 1 & 2 & 3 & 4 \\
\hline $\begin{array}{l}\text { The organization's environment hinders strategy } \\
\text { implementation }\end{array}$ & 0 & 1 & 2 & 3 & 4 \\
\hline \multicolumn{6}{|l|}{ Awareness of the strategy } \\
\hline The strategy is being deliberately kept a secret & 0 & 1 & 2 & 3 & 4 \\
\hline It is assumed that the strategy is already known & 0 & 1 & 2 & 3 & 4 \\
\hline $\begin{array}{l}\text { The communication of the strategy has been } \\
\text { insufficient }\end{array}$ & 0 & 1 & 2 & 3 & 4 \\
\hline $\begin{array}{l}\text { The communication of strategy to different or- } \\
\text { ganizational levels is not perceived as necessary }\end{array}$ & 0 & 1 & 2 & 3 & 4 \\
\hline $\begin{array}{l}\text { The flow of information is disrupted at some } \\
\text { point }\end{array}$ & 0 & 1 & 2 & 3 & 4 \\
\hline The strategy is not correctly understood & 0 & 1 & 2 & 3 & 4 \\
\hline \multicolumn{6}{|l|}{ Organizational systems } \\
\hline $\begin{array}{l}\text { There are not enough resources for strategy im- } \\
\text { plementation }\end{array}$ & 0 & 1 & 2 & 3 & 4 \\
\hline Working procedures conflict with strategy & 0 & 1 & 2 & 3 & 4 \\
\hline $\begin{array}{l}\text { The organizational structure conflicts with strat- } \\
\text { egy }\end{array}$ & 0 & 1 & 2 & 3 & 4 \\
\hline $\begin{array}{l}\text { The connection between strategy and rewarding } \\
\text { system(s) is insufficient }\end{array}$ & 0 & 1 & 2 & 3 & 4 \\
\hline $\begin{array}{l}\text { Different personal roles have not been ade- } \\
\text { quately defined }\end{array}$ & 0 & 1 & 2 & 3 & 4 \\
\hline The concretization of strategy does not succeed & 0 & 1 & 2 & 3 & 4 \\
\hline \multicolumn{6}{|l|}{ Commitment to strategy } \\
\hline $\begin{array}{l}\text { The management does not sufficiently commit } \\
\text { itself to implementation }\end{array}$ & 0 & 1 & 2 & 3 & 4 \\
\hline $\begin{array}{l}\text { The middle-management does not sufficiently } \\
\text { commit itself to implementation }\end{array}$ & 0 & 1 & 2 & 3 & 4 \\
\hline $\begin{array}{l}\text { The operational personnel does not sufficiently } \\
\text { commit itself to implementation }\end{array}$ & 0 & 1 & 2 & 3 & 4 \\
\hline $\begin{array}{l}\text { There is not enough faith for the realization of } \\
\text { strategy }\end{array}$ & 0 & 1 & 2 & 3 & 4 \\
\hline $\begin{array}{l}\text { Strategy implementation conflicts with organiza- } \\
\text { tional culture }\end{array}$ & 0 & 1 & 2 & 3 & 4 \\
\hline
\end{tabular}




\begin{tabular}{|l|l|l|l|l|l|l|}
\hline $\begin{array}{l}\text { Strategy implementation conflicts with certain } \\
\text { personal goals or interests }\end{array}$ & 0 & 1 & 2 & 3 & 4 \\
\hline $\begin{array}{l}\text { Other activities and events divert attention from } \\
\text { strategy implementation }\end{array}$ & 0 & 1 & 2 & 3 & 4 \\
\hline Monitoring and development of implementation & 0 & 0 & 1 & 2 & 3 & 4 \\
\hline The implementation is not evaluated & 0 & 1 & 2 & 3 & 4 \\
\hline $\begin{array}{l}\text { After any change the old direction of activities is } \\
\text { soon regained }\end{array}$ & 0 & 1 & 2 & 3 & 4 \\
\hline $\begin{array}{l}\text { There is no reaction to perceived problems in } \\
\text { implementation }\end{array}$ & 0 & & & & \\
\hline
\end{tabular}




\subsection{APPENDIX 3: INTERVIEW OUTLINE OF INSURANCE}

1 First, would you tell a little about your job? What do you do?

2 What do you understand by the concept of strategy?

3 How would you define communication?

4 In your opinion, what is strategy communication? What does the word strategy communication bring to mind?

5 How is strategy communicated at Insurance?

6 Are you satisfied with Insurance's strategy communication? If not, why?

7 Who communicates strategy at Insurance?

8 Describe your own role in strategy communication / strategy communication process

8.1 How would you develop your role in strategy communication?

8.2 What kind of duties and tasks do you have relating to strategy communication?

8.3 How do you experience / feel about your role (pleasant, unpleasant, important, something you must do but don't like)?

8.4 How would you develop your role in strategy communication?

9 How is strategy communicated at Insurance? In your opinion, what are the central events and occasions in strategy communication? (NOTE: also "informal" events and occasions)

10 What kinds of strategy communication events have you participated during the last year? 
11 In what kinds of situations and events have you communicated strategy? Give examples.

12 How would you develop the way strategy is communicated at Insurance?

13 In your opinion, what kind of knowledge, skills and competencies does strategy communication require from you?

14 In your opinion, what kinds of things related to strategy are the most difficult to communicate in an understandable fashion? Give an example.

15 What kinds of things related to strategy are easiest to communicate? Give an example.

16 What kind of routines / practices / tools / methods you use in strategy communication? (Symbols, stories, slogans, BSC, discussions, meetings, etc.)

16.1 What kind of things you consider to be most effective in strategy communication?

16.2 Do you think you have enough tools and methods that support strategy communication at your disposal?

16.3 How would you further develop the tools and methods used in strategy communication?

17 How have you experienced the (human) interaction regarding strategy communication between you and your

17.1 Subordinates?

17.2 Superiors?

17.3 Peers?

18 What kind of things

18.1 Make interaction more difficult?

18.2 Make interaction easier? 
19 During the last year, what kinds of strategy communication events have you participated in?

19.1 How would you describe these events: What they were like, what kinds of feelings did they evoke in you, why?

19.2 What kind of (human) interaction took place in these events?

20 How would you describe the last strategy communication event you consider successful where you yourself actively interacted and communicated (strategy)?

21 How would you describe the last strategy communication event you consider unsuccessful where you yourself actively interacted and communicated (strategy)?

22 Is there something you think we failed to account for? Would you like to add something? 